\title{
Revision of European species of the genus Rhabdomastix (Diptera: Limoniidae). Part 2: Subgenus Rhabdomastix s. str.
}

\author{
JAROSLAV STARÝ \\ Department of Zoology and Anthropology, Faculty of Science of the Palacký University, tř. Svobody 26, 77146 Olomouc, \\ Czech Republic; e-mail: stary@prfnw.upol.cz
}

Key words. Diptera, Limoniidae, Rhabdomastix, subgenus Rhabdomastix s. str., redescriptions, new synonyms, lectotype designations, new species, distribution, key

\begin{abstract}
The second and final part of a revision of the European species of the genus Rhabdomastix Skuse, 1890 is presented. The subgenus Rhabdomastix s. str. is revised. Seven species are redescribed, Rhabdomastix (Rhabdomastix) japonica Alexander, 1924, R. (R.) laeta (Loew, 1873), R. (R.) borealis Alexander, 1924, R. (R.) edwardsi Tjeder, 1967, R. (R.) subparva Starý, 1971, $R$. (R.) hirticornis (Lackschewitz, 1940) and $R$. (R.) beckeri (Lackschewitz, 1935). Three new synonyms are proposed. Lectotypes of four pertinent nominal species are designated. Descriptions are provided of six species, viz. R. (R.) laetoidea sp. n. (Czech Republic, Slovakia, Bulgaria, Ukraine), $R$. (R.) crassa sp. n. (France, Czech Republic, Slovakia), $R$. (R.) corax sp. n. (Bulgaria, Greece), $R$. ( $R$.) eugeni sp. n. (France, Switzerland, Germany, Czech Republic, Slovakia, Italy, Romania, Bulgaria, Greece, Ukraine, Armenia), $R$. (R.) filata sp. n. (Bulgaria, Greece, European Russia, Turkey, Georgia, Armenia) and R. (R.) georgica sp. n. (Georgia). Male and female terminalia are illustrated for all the species, and a key to species is appended.
\end{abstract}

\section{INTRODUCTION}

In the first part of this revision published recently (Starý, 2003), the taxonomic history of the genus Rhabdomastix Skuse, 1890 was reviewed, its classification outlined and re-assessed, and a new subgenus, Lurdia Starý, 2003, was established. Nine European Lurdia species were treated, and seven of these were described as new.

The second instalment, now presented, deals with the nominotypical subgenus Rhabdomastix s. str., as defined in the first part, i.e. in a broad sense, comprising the majority of species of the former subgenera Rhabdomastix s. str., Palaeogonomyia Meunier, 1899 and Sacandaga Alexander, 1911.

Generally, the same morphological terminology is used as in the first part of this revision (Starý, 2003). The following should be added or repeated:

Acronyms of museums and collections used in the text are as follows: AGB - Collection of A. Godfrey, Barnsley, England, UK; BMNH - The Natural History Museum [formerly British Museum (Natural History)], London, England, UK; ISEZ Institute of Systematics and Evolution of Animals, Kraków, Poland; JSJ - Collection of J. Salmela, Jyväskylä, Finland; JSO - Collection of J. Starý, Olomouc, Czech Republic; MHNN Muséum d'histoire naturelle, Neuchâtel, Switzerland; MMBC Moravské zemské muzeum, Brno, Czech Republic; MZLU Museum of Zoology, Lund, Sweden; NHBB - Naturhistorisches Museum der Burgergemeinde, Bern, Switzerland; NHMW Naturhistorisches Museum, Vienna, Austria; SMOC - Slezské zemské muzeum, Opava, Czech Republic; USNM - National Museum of Natural History, Smithsonian Institution, Washington, D.C., USA; ZFMK - Zoologisches Forschungsinstitut und Museum Alexander Koenig, Bonn, Germany; ZMAN - Zoological Museum, Amsterdam, The Netherlands; ZMHB -
Museum für Naturkunde der Humboldt-Universität, Berlin, Germany.

Numbers in brackets following Czech and Slovak localities in the Material examined sections refer to grid references as defined by Zelený (1972).

Colour characters of species are described from drymounted specimens. Unless otherwise stated in the sections on Material examined, the material under study is dry-mounted and collected by netting. Some specimens were dried after preservation in ethanol and mounted on points in the course of the study.

\section{SUBGENUS RHABDOMASTIX S. STR.}

For references, see Starý, 2003: 590-591.

Diagnosis. Small to medium-sized species (cf. Figs 1-4). Head. Antenna 16-segmented, of variable length, from very short (Fig. 7), about twice as long as head, to notably long (Fig. 11), longer than body. Flagellomeres short, oval, decreasing in size, especially in breadth, towards apex of short antenna, or considerably long, cylindrical or spindle-shaped, with terminal flagellomere of long antenna very small. In latter case, antenna considerably shorter in female (Fig. 12). Setae on antenna well differentiated into long stiff verticils and shorter delicate, suberect pubescence (some species, Figs 5, 6, 10), or either pubescence (other species, Figs 7, 9, 12) or verticils (male long antenna, Fig. 11) scarcely apparent. Palpus short, subequal in length to diameter of head, with terminal palpomere only a little longer than penultimate (Fig. 14), or longer, with terminal palpomere twice as long as penultimate one (Fig. 13).

Thorax. Wing venation (cf. Figs $1-4)$ : $\mathrm{Sc}_{1}$ ending from shortly beyond origin of Rs to about at three quarters of 
Rs length (at half of Rs length or beyond it in European species). $\mathrm{Sc}_{2}$ lacking or faintly apparent at tip of $\mathrm{Sc}_{1}$ or some distance before it . $\mathrm{R}_{3}$ very short, from one-fifth to one-eighth of $\mathrm{R}_{4}$ length, vertical or virtually so, forming a $90^{\circ}$ with $\mathrm{R}_{4}$. Discal cell generally hexagonal, with proximal section of $\mathrm{M}_{3+4}$ (forming lower side of discal cell) distinctly angled near mid-length, at attachment of $\mathrm{m}$-cu. Distal sections of $\mathrm{M}_{1+2}$ and $\mathrm{M}_{3}$ (beyond discal cell) considerably arched.

Abdomen. Male terminalia (cf. Fig. 17 and other relevant figures): Segment 9 generally parallel-sided, simple, with at most small lobe dorsally at posterior margin on each side of median interruption (except in beckeri, Fig. 44). Gonostyli generally shorter than those in Lurdia; outer one terminating in curved apical spine, or broadly rounded and without apparent spine; inner one fleshy, generally conical, variously swollen, generally a little shorter than outer gonostylus. Interbase membranous, pale, mostly dilated before apex into variously shaped apical blade, not connected membranously to its counterpart at about one third of its length. Female terminalia (cf. Fig. 19 and other relevant figures) with cercus and hypogynial valve of moderate length, the former at most slightly exceeding length of tergite 10. Spermathecae (Figs 46-56) two or three in number, spherical, oval, or reniform, subequal in size to each other, or, if three, one spermatheca sometimes tending to be smaller than other two.

Discussion. The two subgenera, Lurdia and Rhabdomastix s. str., were compared in the first part of this revision (Starý, 2003). It should be noted that the venational pattern in Rhabdomastix s. str., with its vertical (subvertical) $\mathrm{R}_{3}$, combined with the hexagonal discal cell and distinctly arched $\mathrm{M}_{1+2}$ and $\mathrm{M}_{3}$, is quite unique within the Limoniidae. The venation may vary in details even within a species, especially in aspects such as the verticality of $\mathrm{R}_{3}$ or the length ratio of $\mathrm{R}_{3}$ to $\mathrm{R}_{4}$.

Rhabdomastix s. str. species, as those of Lurdia, are mainly distinguished by details in the structure of the male and female terminalia, in the latter case predominantly by the number and size of the spermathecae. Other internal structures of the female terminalia, such as the infra-anal (supravaginal) plate, sternum 9 and genital fork (vaginal apodeme) are not sufficiently differentiated, and, of these, only the vaginal apodeme may sometimes provide some species-specific peculiarities (cf. Figs 18, 25, 28). If from the same region, some species may well be separated by the body colouration. However, this only applies to dry-mounted specimens.

Distribution. Worldwide.

\section{REVISION OF EUROPEAN SPECIES OF THE SUBGENUS RHABDOMASTIX S. STR.}

Compared to the subgenus Lurdia, representatives of the European Rhabdomastix s. str. species are more diverse structurally, representing several species clusters, or evolutionary trends. However, within a cluster, the taxonomic situation parallels that in Lurdia: species may be very similar to each other in both external and genital characters that, in addition, vary in a certain degree. Moreover, some Rhabdomastix s. str. species have, or are presumed to have, wide ranges of distribution, and some show infraspecific variation in body colouration, a trait not observed in Lurdia. Consequently, to properly recognising species limits, large series of specimens have been examined from Central Europe where, fortunately, many species occur sympatrically, even syntopically. This was combined with the examination of additional specimens from more remote areas. Without this extensive and geographically diverse material, totalling over 2500 specimens, a re-assessment of the European Rhabdomastix s. str. species would not have been possible

This revision of the European Rhabdomastix s. str. has been in progress, with interruptions, for an exceedingly long time. Many specimens from various institutions were examined as early as in the late 1970's. In the course of the study, some species concepts were modified. Therefore, as many as possible, relevant specimens, especially types, were re-examined quite recently (2002-2003).

In all, thirteen Rhabdomastix s. str. species are treated here. Seven species are redescribed, viz. $R$. (R.) japonica Alexander, 1924, R. (R.) laeta (Loew, 1873), R. (R.) borealis Alexander, 1924, R. (R.) edwardsi Tjeder, 1967, $R$. (R.) subparva Starý, 1971, R. (R.) hirticornis (Lackschewitz, 1940) and $R$. (R.) beckeri (Lackschewitz, 1935). Three new synonyms are proposed: $R$. hilaris Edwards, 1938 and $R$. cunctans Tjeder, 1955 are treated as junior synonyms of $R$. (R.) japonica, and $R$. lapponica Tjeder, 1936 as a junior synonym of $R$. (R.) borealis. The latter synonymy had been tentatively suggested by Savchenko et al. (1992). Lectotypes of hilaris, laeta, hirticornis and beckeri are designated. Descriptions are provided for six new species, viz. $R$. (R.) laetoidea sp. n., $R$. (R.) crassa sp. n., $R$. (R.) corax sp. n., R. (R.) eugeni sp. n., $R$. (R.) filata sp. n. and $R$. (R.) georgica sp. n., the latter being extra-European.

Some European Rhabdomastix s. str. species have often been covered in the literature. The many species records listed below in the references sections under species headings are, however, largely suspect because of subsequently newly described species. Practically all the small, darkly coloured species had been identified as $R$. schistacea (Schummel, 1829), one of the species most commonly treated in the literature, until Tjeder (1967) described $R$. edwardsi. The taxonomic situation in Rhabdomastix at that time may best be illustrated by the fact that P. Lackschewitz, a distinguished student of Limoniidae who contributed considerably to a better knowledge of the group in Europe, had identified a series of specimens deposited in NHMW as belonging to R. schistacea (cf. Lackschewitz, 1940). Within this series, four species (edwardsi, crassa, filata, subparva) have now been differentiated (see respective Material examined sections). Schummel's description of Limnobia schistacea, based on a single female from Wrocław (Breslau), Poland, although clearly representing a Rhabdomastix s. str. (cf. Schummel, 1829, Tab. 2, Fig. 2), deals with a small species (" $2 \frac{1}{2}$ " $=\sim 5.5 \mathrm{~mm}$ ) having the head and 
thorax of slate colour ("schiefergrau"), a yellowish grey abdomen with segments seamed with yellowish, $\mathrm{R}_{3}$ more than its own length beyond the tip of $\mathrm{R}_{1}$, and $\mathrm{A}_{2}$ long, ending beyond the origin of Rs. This combination of characters is not known within the European Rhabdomastix s. str. Therefore, Limnobia schistacea is considered a nomen dubium (cf. also Starý \& Rozkošný, 1970). Since literature references are as complete as possible for each species treated, the same is provided for L. schistacea at the end of this paper.

Considering the material below, collected by me in the Czech Republic and Slovakia, many Rhabdomastix s. str. species may seem to be common. The rich material available from these territories, including that of new species (laetoidea, crassa, eugeni) is, however, a result of many years' collecting activity at specific habitats to which these species are strictly confined, namely sandy or gravelly banks of streams. Actually, there is a single common and largely eurytopic species in Central Europe, $R$. (R.) subparva. Other regions may show different relations.

The European Rhabdomastix species of the former subgenus Sacandaga were subdivided into three species groups by Savchenko (1982), the lurida, laeta and edwardsi groups. As the lurida group represents now the subgenus Lurdia (cf. Starý, 2003), and species such as $R$. hirticornis (formerly in the subgenus Palaeogonomyia) are treated here within Rhabdomastix s. str., the above concept had to be modified. Anyway, considering the world fauna, differences between species groups in Rhabdomastix s. str. should be considerably greater than are those found between the laeta and edwardsi groups of Savchenko (1982). Based on various characters, three clusters, or species complexes, may be distinguished preliminarily within the European Rhabdomastix s. str., namely those centred around $R$. (R.) laeta, $R$. (R.) edwardsi and $R$. (R.) hirticornis. In addition, $R$. (R.) beckeri is a distinctive species considerably different from all the others, and its affinities remain in question.

\section{R. (R.) laeta complex (japonica, laeta, laetoidea, borealis)}

Antenna short to moderately long, with pubescence on flagellomeres distinct (Figs 5-6); palpus short; $\mathrm{R}_{3}$ about its own length beyond tip of $\mathrm{R}_{1}$ (Figs 1-2); $\mathrm{A}_{2}$ ending beyond origin of Rs (Figs 1-2); segment 9 of male terminalia broader than long (Figs 17, 20, 22, 24).

\section{R. (R.) edwardsi complex (edwardsi, crassa, corax, eugeni, filata, subparva)}

Antenna short, with pubescence on flagellomeres not apparent (Figs 7-9); palpus short (Fig. 14); $\mathrm{R}_{3}$ more than its own length beyond tip of $\mathrm{R}_{1}$ (Fig. 4); $\mathrm{A}_{2}$ ending before origin of Rs (Fig. 4); segment 9 of male terminalia longer than broad (Figs 27, 30, 32-35).

\section{R. (R.) hirticornis complex (hirticornis, georgica)}

Male antenna very long, subequal to body length, with verticils reduced and pubescence greatly developed (Fig. 11); palpus long (Fig. 13); $\mathrm{R}_{3}$ more than its own length beyond tip of $\mathrm{R}_{1} ; \mathrm{A}_{2}$ ending before origin of Rs; segment 9 of male terminalia longer than broad (Figs 40-41).

\section{R. (R.) beckeri}

Antenna short, with pubescence on flagellomeres distinct (Fig. 10); palpus short; $\mathrm{R}_{3}$ more than its own length beyond tip of $\mathrm{R}_{1}$ (Fig. 3); $\mathrm{A}_{2}$ ending opposite to origin of Rs (Fig. 3); differs considerably from the species above by having milky wings, with narrow darker seams along veins, and many details in structure of male terminalia. It most probably belongs to a different species cluster.

As already noted, the classification above is preliminary, since the characters used have unequal value. The laeta and edwardsi complexes are well defined, based on several independent features, whereas the so-called hirticornis complex, although distinguished at once by the long male antennae, can hardly be assigned the same weight. The conspicuousness of the long antennae is responsible for their being generally overvalued as a taxonomic character. The length of the antennae, however, vary extensively within genera and subgenera of the chioneine Limoniidae, unlike most other characters.

\section{KEY TO EUROPEAN SPECIES OF THE SUBGENUS RHABDOMASTIX S. STR.}

$0 \quad \mathrm{R}_{3}$ oblique, from one-third to one-fourth length of $\mathrm{R}_{4}$; discal cell generally pentagonal; distal sections of $\mathrm{M}_{1+2}$ and $\mathrm{M}_{3}$ nearly straight (Starý, 2003, Figs 4-5); interbases of male terminalia sclerotised distally, connected to each other through membranous strip (Starý, 2003, e.g. Fig. 7); cercus of female terminalia elongate, about twice length of tergite 10 (Starý, 2003, Fig. 18). . . . subgenus Lurdia Starý, 2003

- $\mathrm{R}_{3}$ subvertical, from one-fifth to one-eighth length of $\mathrm{R}_{4}$; discal cell generally hexagonal; distal sections of $\mathrm{M}_{1+2}$ and $\mathrm{M}_{3}$ considerably arched (Figs 1-4); interbases of male terminalia membranous, not interconnected (e.g. Fig. 17); cercus of female terminalia at most slightly exceeding length of tergite 10 (e.g. Fig. 19); (subgenus Rhabdomastix

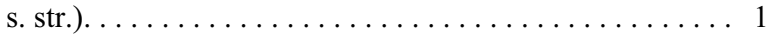

1 General colouration of pleuron pale yellow to yellowish brown; $\mathrm{R}_{3}$ about its own length beyond tip of $\mathrm{R}_{1}$ (Figs 1-2); $\mathrm{A}_{2}$ ending beyond origin of Rs (Figs 1-2); (laeta complex). .

General colouration of pleuron from grey of various hues to black; $\mathrm{R}_{3}$ more than its own length beyond tip of $\mathrm{R}_{1}$ (Figs 3-4); $A_{2}$ ending opposite or before origin of Rs (Figs 3-4). .

llow; femora yellow throughout; apical blade of interbase triangular or quadrangular, without conspicuous tooth (Figs 17, 20, 22); vaginal apodeme narrow to moderately broad (Fig. 18). . . . . . . 3

- General colouration of pleuron yellowish brown; femora considerably darkened distally; apical blade of interbase terminating in large acute tooth at outer margin (Fig. 24); vaginal apodeme very broad distally, transversely oblong or semicircular (Fig. 25) . . . . . . . . . . R. (R.) borealis

3 Antenna short, not reaching base of wing, with very short pubescence, at most subequal to half breadth of their respective flagellomeres (Fig. 5); apical blade of interbase very broad (Fig. 17); spermathecae as in Fig. 46. . . . . . . . . . $\ldots \ldots \ldots \ldots \ldots \ldots \ldots \ldots \ldots \ldots \ldots . \ldots \ldots$. $(R$.$) japonica$ 
- Antenna moderate in length, reaching base of wing, with longer pubescence, subequal to breadth of their respective flagellomeres (Fig. 6); apical blade of interbase narrower

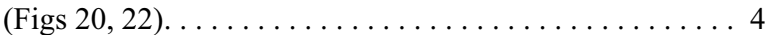

4 Wing broad, about three times as long as broad (cf. Fig. 1); aedeagus long and slender, nearly twice length of narrow vesica (Fig. 20); spermathecae small (Figs 21, 47). . . . . . . . R. (R.) laeta

- Wing narrow, about four times as long as broad (Fig. 2); aedeagus short and broad, subequal in length to rather broad vesica (Fig. 22); spermathecae large (Figs 23, 48). . . . . . . ......................... R. (R.) laetoidea $\mathrm{sp.} \mathrm{n}$

5 Male antenna very long, subequal to or longer than entire body (Fig. 11); palpus long (in both sexes), distinctly exceeding diameter of head; terminal palpomere nearly twice as long as penultimate (Fig. 13); (hirticornis complex).


Male antenna short, reaching at most base of wing (Figs 7-10); palpus short (in both sexes), subequal to diameter of head; terminal palpomere only slightly longer than penultimate (Fig. 14) . . . . . . . . . . . . . . . . . . . . 7

6 Male antenna subequal in length to body; apical blade of interbase generally spoon-shaped (Fig. 40); spermathecae medium-sized, reniform (Figs 42, 54). . . R. (R.) hirticornis Male antenna somewhat longer than body; apical blade of interbase triangular, drawn out into sharp long point at inner margin (Fig. 41); spermathecae larger (Figs 43, 55). . . . . .

$R$. (R.) georgica sp. n.

7 Wing somewhat milky, with narrow darker seams along veins; antenna with distinct pubescence (Fig. 10); $\mathrm{A}_{2}$ ending opposite to origin of Rs (Fig. 3); segment 9 of male terminalia broader than long, with conspicuous triangular lobes dorsally (Fig. 44); inner gonostylus broad, broadly rounded at apex (Fig. 44) . . . . . . . . . . . R . (R.) beckeri

Wing clear, hyaline or infuscated, without any pattern; antenna with pubescence not apparent (Figs 7-9); $A_{2}$ ending before origin of Rs (Fig. 4); segment 9 of male terminalia longer than broad; inner gonostylus tapered distally into obtuse apex (Figs 27, 30, 32-35); (edwardsi complex). . . 8

8 Antenna with pedicel large and flagellum very slender, filiform (Fig. 9); body bicoloured, light grey on thorax, pale brown on abdomen; apodeme of vesica large, broadly fanshaped (Fig. 34); spermathecae two, spherical, with sclerotised parts of ducts about one third of spermathecal diameter (Figs 38, 52) ................... (R.) filata sp. n.

- Antenna of normal structure (Figs 7-8); body colouration darker, mostly single-coloured; apodeme of vesica narrower (Figs 27, 30, 32-33, 35); spermathecae two or three, with sclerotised parts of ducts shorter (Figs 29, 31, 36-37, 39, $50-51,53) \ldots \ldots \ldots \ldots \ldots \ldots \ldots \ldots \ldots \ldots . \ldots \ldots$

$9 \mathrm{R}_{4}$ with numerous macrotrichia, about 20, both dorsally and ventrally; outer gonostylus tapered distally (Fig. 35); vesica narrow (Fig. 35); cercus broad, abruptly upturned before apex (Fig. 39); spermathecae two, very large (Figs 39, 53). . $\ldots \ldots \ldots \ldots \ldots \ldots \ldots \ldots \ldots \ldots . . \ldots \ldots$. $(R$.$) subparva$

- $\mathrm{R}_{4}$ bare or with fewer macrotrichia, mostly dorsally; outer gonostylus more or less parallel-sided; vesica broad, bulbous (Figs 27, 30, 32-33); cercus slender, gently upturned; spermathecae two or three, smaller (Figs 24, 31, 36-37). ... ................................. 10

10 Coxae yellow; outer gonostylus rounded at apex, with apical spine barely distinct or lacking (Fig. 33); apodeme of vesica shorter than vesica (Fig. 33); spermathecae two, mediumsized, short-oval to reniform (Figs 37, 54)........... ....................... R. (R.) eugeni sp.
Coxae from greyish brown to blackish; outer gonostylus with distinct apical spine (Figs 27, 30, 32); apodeme of vesica subequal in length to vesica (Figs 27, 30, 32); spermathecae three, small, spherical (Figs 24, 31, 36, 50). . . 11

$11 \mathrm{R}_{4}$ with about 10 macrotrichia; outer gonostylus evenly arched (Fig. 32); inner gonostylus slender (Fig. 32) . . . . . . $\ldots \ldots \ldots \ldots \ldots \ldots \ldots \ldots . \ldots \ldots$. $(R.) \operatorname{corax} \mathrm{sp} . \mathrm{n}$. $\mathrm{R}_{4}$ bare or with only a few macrotrichia; outer gonostylus straight (Figs 27, 30); inner gonostylus broader (Figs 27, 30).

............................ 12

12 General coloration of pleuron bluish grey; interbase long and slender, with apical blade rather narrow (Fig. 27). . . . . .

R. (R.) edwardsi

- General colouration of pleuron black; interbase shorter and broader, with apical blade broader, rounded (Fig. 30). . . . . . . ........................ R. (R.) crassa sp. n.

\section{Rhabdomastix (Rhabdomastix) japonica Alexander, 1924}

(Figs 1, 5, 17-19, 46)

Rhabdomastix (Sacandaga) japonica Alexander, 1924b: 69 (description).

Rhabdomastix (Sacandaga) japonica: Alexander, 1925b: 4 (faun. record); Alexander, 1940: 51 (note); Alexander, 1954: 302 (faun. record), Fig. 45 (wing); Ishida, 1960: 34 (list); Ishida, 1965: 38 (list); Savchenko \& Krivolutskaya, 1976: 86 (faun. record, key); Savchenko, 1983: 95, 96 (questioned faun. record, key); Savchenko, 1989: 264 (tentative synonymy with laeta, faun. record); Savchenko et al., 1992: 315 (Palaearctic catalogue, tentative synonymy with laeta); Sidorenko, 2001: 63 (key).

Rhabdomastix hilaris Edwards, 1938: 113, 114 (description, key), Text-figs 21f (male antenna), 22a,b (male terminalia), P1. 5, Fig. 10 (wing). - syn. n.

Rhabdomastix hilaris: Tjeder, 1947: 29 (note); Coe, 1950: 53 (key), Figs 23a-c (male terminalia); Falk, 1991: 139 (faun. record); Rotheray \& Robertson, 1993: 4, 17 (faun. record); Howe, 1997: 11 (faun. record).

Rhabdomastix (Sacandaga) hilaris: Savchenko, 1972: 729 (faun. record); Mannheims \& Savchenko, 1973: 257, 265 (faun. record); Noll, 1985: 121 (diagnosis, faun. record, note), Map 60 (distribution).

Gonomyia (Rhabdomastix) laeta: Lackschewitz, 1940: 56 (alternatively as Gonomyia (Sacandaga), faun. record), Text-fig. 1 (wing) [partim, see present revision].

Rhabdomastix laeta: Mannheims, 1964: 7 (faun. record); Mannheims, 1967: 473 (faun. record) [both see present revision].

Rhabdomastix (Sacandaga) laeta: Mendl, 1984a: 7 (faun. record); Mendl, 1986: 278 (faun. record) [both see present revision].

Rhabdomastix cunctans Tjeder, 1955a: 226 (description). - syn. n.

Rhabdomastix cunctans: Tjeder, 1955b: 246 (list).

Rhabdomastix (Sacandaga) cunctans: Mendl, 1978: 373 (list); Savchenko et al., 1992: 315 (Palaearctic catalogue, tentative synonymy with laeta); Reusch \& Oosterbroek, 1997: 132 (list).

Diagnosis. General colouration yellow to pale yellow, sometimes conspicuously patterned with deep dark brown on thorax, including three stripes on prescutum. Antenna short, with very short pubescence on flagellomeres. Wing broad. $\mathrm{A}_{2}$ ending beyond origin of Rs. Legs yellow throughout. Male terminalia with apical blade of interbase 

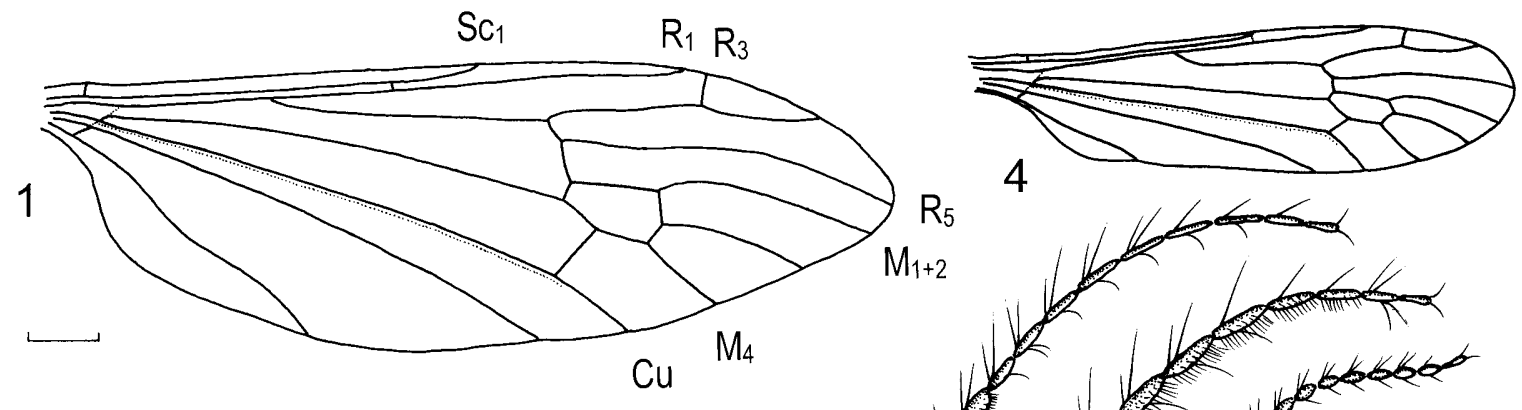

4
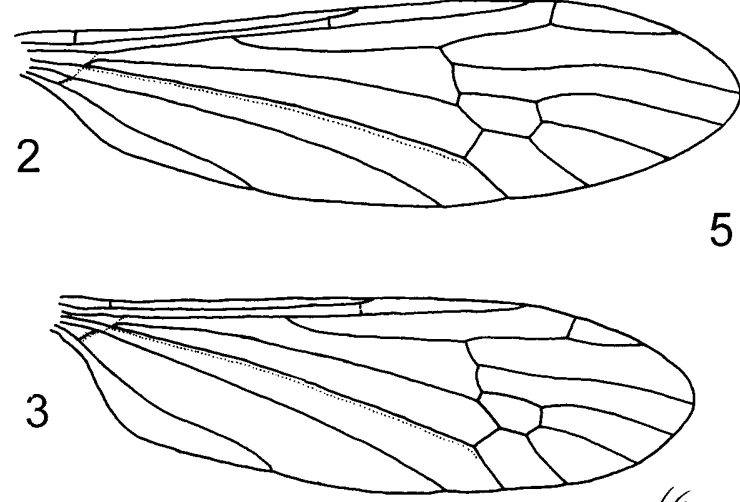

5
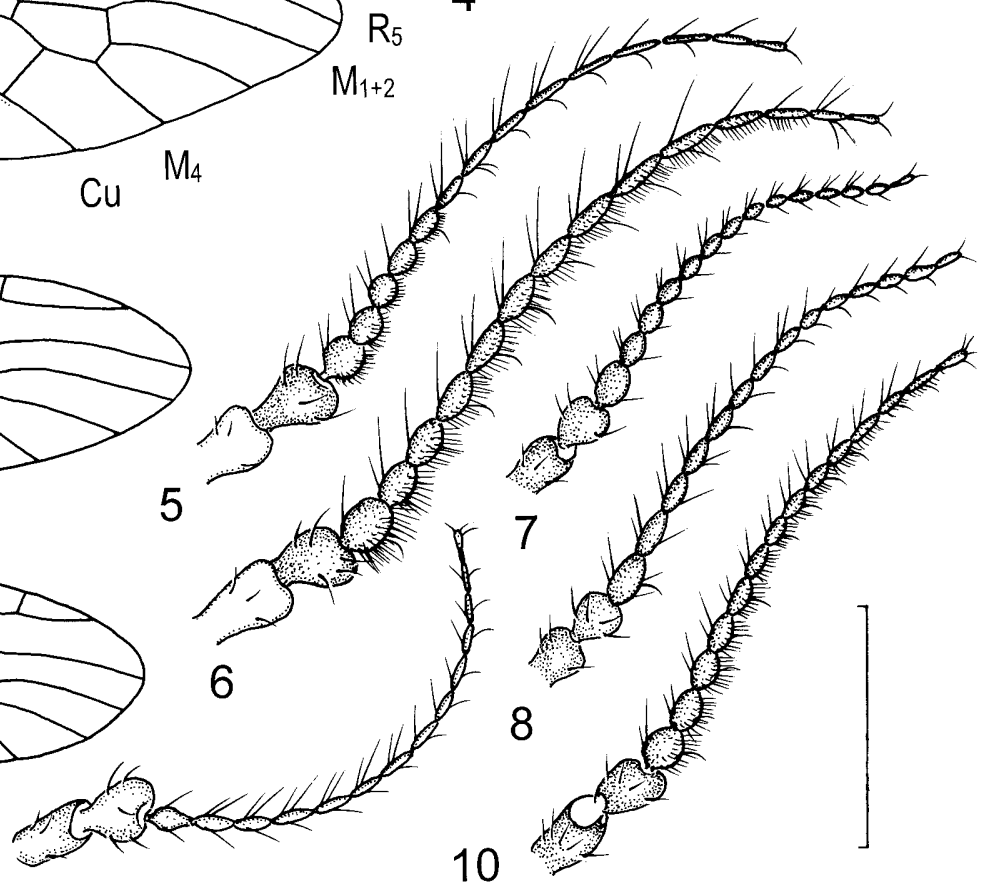

10

Figs 1-10. Male wing. 1 - Rhabdomastix (Rhabdomastix) japonica Alexander, 1924 (Slovakia: Tatranská Kotlina); $2-R$. (R.) laetoidea sp. n. (paratype, Czech Republic: Hrubá Voda nr. Olomouc); $3-R$. (R.) beckeri (Lackschewitz, 1935) (Slovakia: Malé Trakany); $4-R$. (R.) crassa sp. n. (paratype, Czech Republic: Hrubá Voda nr. Olomouc). 5-10. Male antenna. $5-R$. (R.) japonica Alexander, 1924 (Slovakia: Tatranská Kotlina); $6-R$. (R.) laeta (Loew, 1873) (Czech Republic: Velké Losiny); $7-R$. (R.) crassa sp. n. (paratype, Czech Republic: Hrubá Voda nr. Olomouc); $8-R$. (R.) eugeni sp. n. (paratype, Slovakia: Snina); $9-R$. (R.) filata sp. n. (paratype, Lebanon: Bacharré); $10-R$. (R.) beckeri (Lackschewitz, 1935) (Slovakia: Malé Trakany). Scale bars $0.5 \mathrm{~mm}$.

very broad and aedeagus long and slender. Female terminalia with three spherical medium-sized spermathecae.

Redescription. Medium-sized species. Body length 4.5-7.5 mm, wing length 5-9 mm.

Colour. General colouration yellow to pale yellow, subshiny, with darker markings on thorax. Antenna dark brown, scape mostly yellow. Prescutum pale yellow laterally, with three broad darker stripes. Scutum and mediotergite (postscutellum) similarly darker, restrictedly patterned with yellow. Scutellum pale yellow. Pleuron mostly yellow, patterned with sulphur yellow in upper part, darker below, especially on lower portion of katepisternum and meron. Colouration of thorax practically identical in distribution of darker markings with that of two following species (laeta, laetoidea); in contrast to these, however, considerably variable in actual hue of pattern, varying from little-distinct, yellowish brown to sharply pronounced, deep dark brown. Wing tinged with yellowish. Halter pale yellow. Legs yellowish brown to yellow throughout, femora not darkened distally. Abdomen yellowish brown to brown.

Head. Antenna (Fig. 5) comparatively short, not reaching to base of wing. Proximal three flagellomeres nearly spherical, following ones gradually narrowed and lengthened towards apex of antenna. Longest verticils on flagellomeres slightly exceeding length of their respective segments. Pubescence very short, suberect, subequal in length to half breadth of respective segments, or even shorter, distinct only on proximal four or five flagellomeres. Palpus short.

Thorax. Wing (Fig. 1) rather broad, about three times as long as broad, with comparatively short stalk. $\mathrm{Sc}_{1}$ ending before fork of Rs, at about three quarters of Rs length. $\mathrm{Sc}_{2}$ not apparent, or slightly so some distance before tip of $\mathrm{Sc}_{1} . \mathrm{R}_{3}$ about its own length, or less, beyond tip of $R_{1}$. $R_{4}$ varying in number of macrotrichia, but generally with only few. $A_{2}$ considerably sinuous, ending distinctly beyond origin of Rs. Halter moderately long, reaching to about posterior margin of abdominal tergite 2 .

Abdomen. Male terminalia (Fig. 17). Segment 9 broader than long. Gonocoxite comparatively long and slender. Outer gonostylus short, less than half length of gonocoxite, gently and evenly arched, somewhat broadened before apex, with small apical spine. Inner gonostylus generally conical. Aedeagal complex as in Fig. 17. Interbase moderate in length, reaching to about half length of gonocoxite, abruptly expanded distally to form broad triangular, sometimes nearly quadrangular apical blade, microscopically serrate at distal margin. Aedeagus very long and slender, nearly twice length of vesica, the 


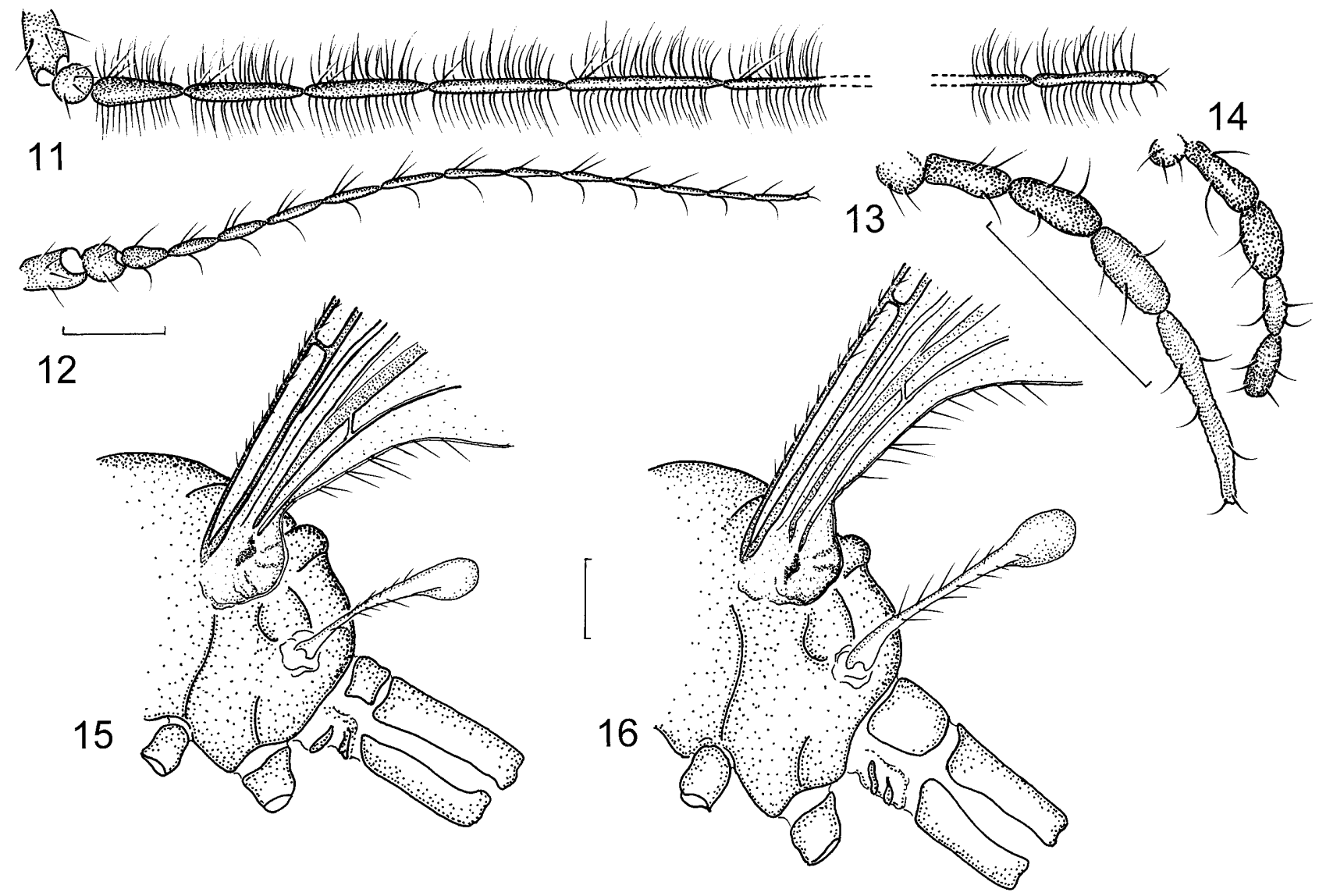

Figs 11-16. 11-12. Rhabdomastix (Rhabdomastix) hirticornis (Lackschewitz, 1940) (Slovakia: Zboj), antenna of male (11) and female (12). 13-14. Palpus. 13 - R. (R.) hirticornis (Lackschewitz, 1940) (Slovakia: Zboj); 14 - R. (R.) crassa sp. n. (paratype, Czech Republic: Hrubá Voda nr. Olomouc). 15-16. Base of wing and halter. $15-R$. (R.) eugeni sp. n. (paratype, Slovakia: Snina); $16-R$. (R.) subparva Starý, 1971 (Czech Republic: Hrubá Voda nr. Olomouc). Scale bars 0.25 mm.

latter comparatively small and narrow. Apodeme of vesica spine-like in dorsal aspect, subequal in length to vesica. Female terminalia (Figs 18-19, 46). Cercus moderately broad, slightly exceeding length of tergite 10 , gently upturned. Vaginal apodeme moderately broad. Spermathecae three, spherical, intermediate in size between those of $R$. (R.) laeta and $R$. (R.) laetoidea sp. n., with sclerotised parts of ducts thin, slightly shorter than spermathecal diameter.

Material examined. Rhabdomastix (Sacandaga) japonica: Holotype + (monotypy): Japan, Honshu, Tokyo, 24.v.1922 (T. Esaki leg.) (USNM), labelled: “Tokyo, Japan May 24, 1922 (Teiso Esaki)" (hand-written), "Holotype Rhabdomastix japonica C.P. Alexander" (partly printed, red). The specimen is glued onto a triangular cardboard point, without right wing, fore and hind right legs and apex of abdomen. The wing mounted on a slide, labelled with the same data, with the inscription "Holotype 2509". Terminalia dissected and placed in a sealed plastic tube with glycerine, pinned with the specimen.

Rhabdomastix hilaris: In the original description, Edwards (1938: 114) did not designate holotype, nor did he specify the number of specimens. According to N. Wyatt (e-mail comm.), four male syntypes are deposited in BMNH. Lectotype $\delta$ (present designation): Great Britain, Scotland, Perth, Rannoch, 14.vii.1917 (J.J.F.X. King leg.) (BMNH), labelled: "Rannoch. 14 Jly-17 J.J F-X King" (partly printed), "Ex Coll. J.J.F.X.
King. B.M. 1936-800" (printed), "Rh. hilaris Edw" (handwritten), "Rhabdomastix laeta (Loew) ô Starý det. 1978" (partly printed), "Syntype" (a green-margined circular label, printed), "Syntype Rhabdomastix hilaris Edwards det. J.E. Chainey, 1996" (partly printed). Accordingly labelled as lectotype ("Lectotype Rhabdomastix hilaris Edwards J. Starý 2003", printed red label) and identified by me as $R$. (R.) japonica. The specimen is micro-pinned on a celluloid slide, with right fore leg attached, all mid and hind legs glued to the specimen at proper places (?) and left fore leg glued onto the celluloid slide; apex of abdomen cut off. Terminalia dissected and preserved in a drop of Canada balsam on another celluloid slide, pinned with the specimen. Lectotype here designated to stabilise the current concept of the name. Paralectotypes: Great Britain, Scotland, Inverness-shire, Aviemore, 27.vi.1903, 10 , 2.vii.1903, 10, Nethy Bridge, 2.vii.1906, $1 \delta^{\star}$ (all J.J.F.X. King) (BMNH), examined by me in 1970's, not labelled as paralectotypes.

Rhabdomastix cunctans: Holotype ô (monotypy): Sweden, Dlr., Mora, Vensnäsudden, 14.viii.1955 (B. Tjeder leg.) (MZLU), labelled: "Dlr. Mora Vensnäsudden 14.VIII.1955 Bo Tjeder" (printed, with hand-written date), "Holotypus Rhabdomastix cunctans ơ Tjeder" (partly printed, red), "Rhabdomastix laeta (Loew) đ̊ Starý det. 1978" (partly printed); identified by me as $R$. (R.) japonica. The specimen, in nearly perfect condition, is glued onto a triangular cardboard point, with only tarsus of left fore leg and apex of abdomen broken off; right fore leg glued onto the point. Terminalia dissected and placed in a corked glass tube with glycerine on a separate pin labelled 

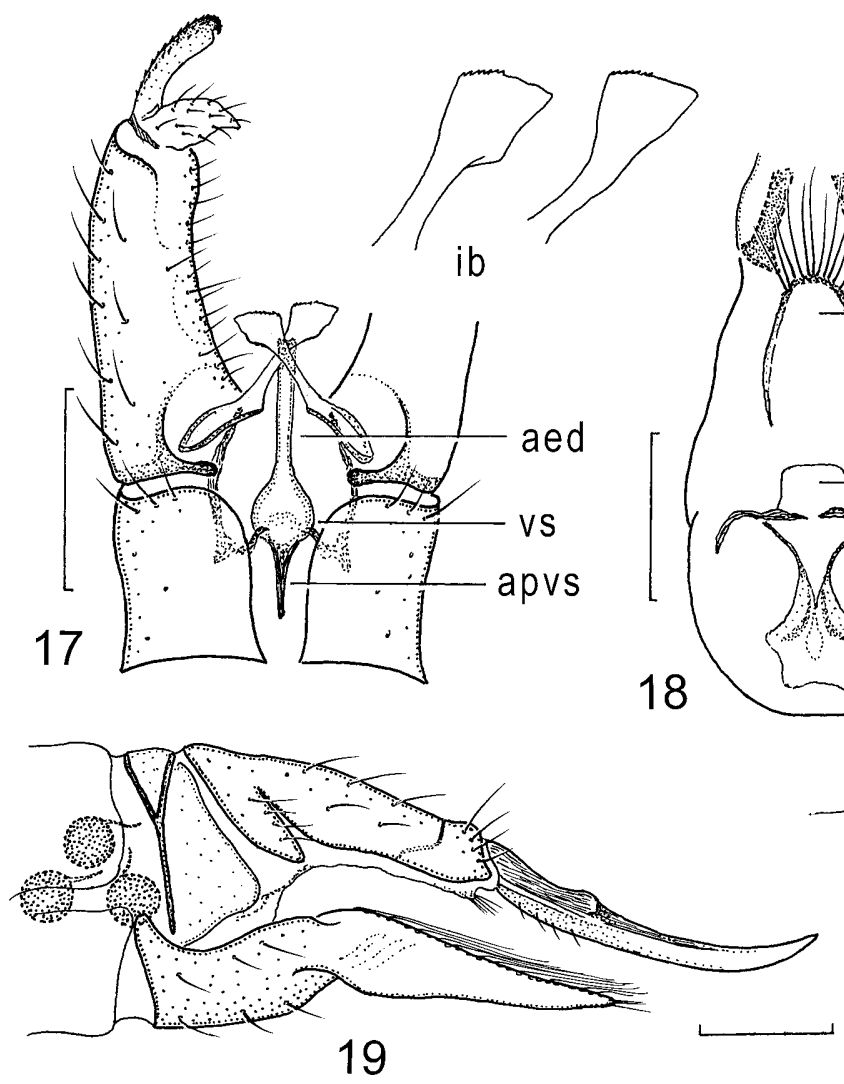

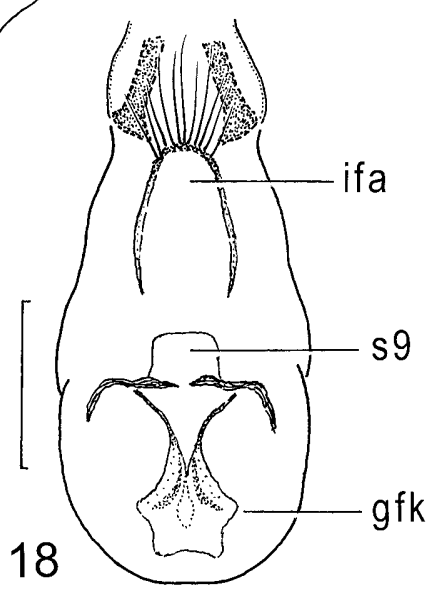

20
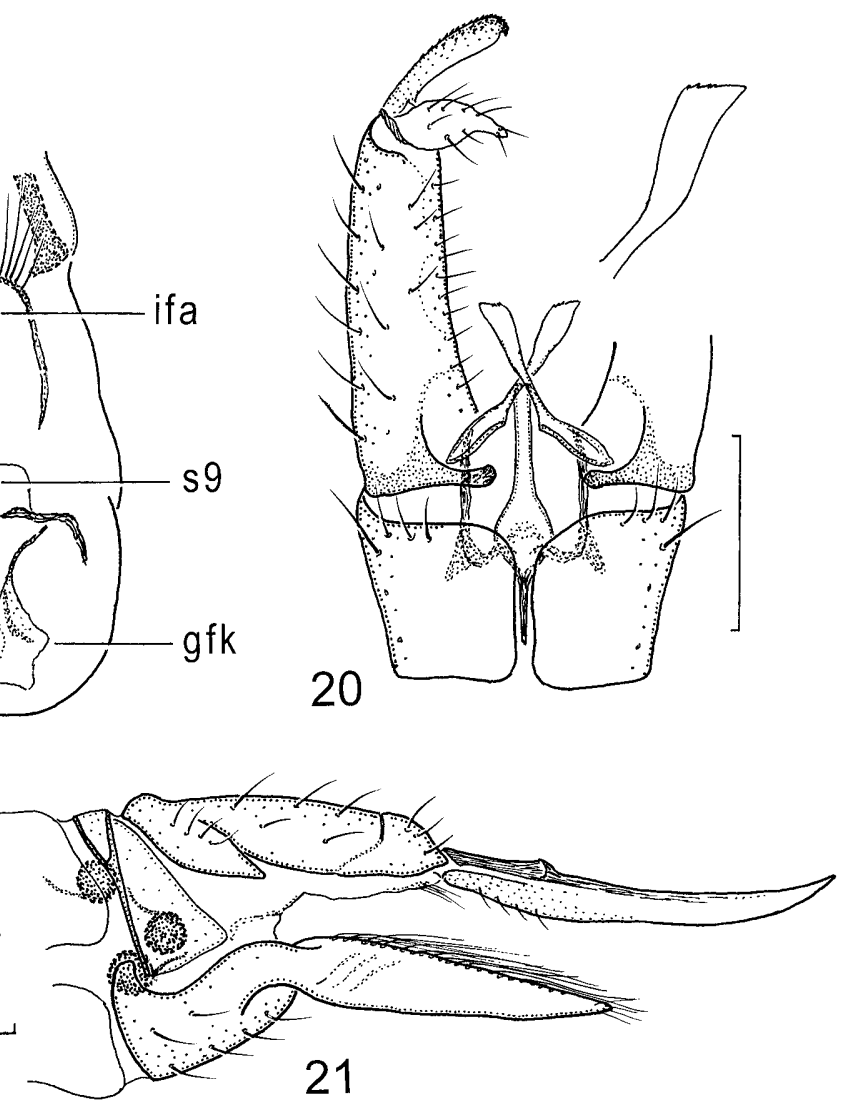

Figs 17-21. 17-19. Rhabdomastix (Rhabdomastix) japonica Alexander, 1924 (Slovakia: Tatranská Kotlina). 17 - male terminalia, general view, dorsal (details show variation in shape of apical blade of interbase); 18-19 - female terminalia, internal structures, ventral (18) and general view, lateral (19). 20-21. R. (R.) laeta (Loew, 1873) (Czech Republic: Velké Losiny). 20 - male terminalia, general view, dorsal; 21 - female terminalia, general view, lateral. Scale bars $0.25 \mathrm{~mm}$. aed - aedeagus; apvs - apodeme of vesica; gfk - genital fork (vaginal apodeme); ib - interbase; ifa - infra-anal (supravaginal) plate; s9 - sternum 9; vs - vesica.

"Rhabdomastix cunctans Tjed. holotype đ̄" (in Tjeder's handwriting).

Other material examined $(56 \hat{\jmath}, 20$ o $)$ : Great Britain: Scotland: Scottish Highlands, Dorbuch Burn, 19.vii.1991, 10 (A.E. Stubbs leg.); Perth, R. Tay nr. Caputh, 8.viii.1977, $3 \sigma^{-}$(A.M. Hutson leg.) (all JSO). Switzerland: Canton Genève: Croix-deRozon, 2.-8.vii.1979, 1ㅇ, 9.-15.vii.1979, 1 đ (Ch. Dufour \& W. Geiger leg.; Malaise light trap); Sézenove, early viii.1980, 1 으 (L. Rezbanyai leg.) (MHNN; in ethanol). Canton Bern: Lauenen (1300 m), 21.vii.1979, 1 đ (V. Puthz leg.) (ZFMK; in ethanol). Canton Ticino: Gudo Demanio $(210 \mathrm{~m})$, middle viii.1981, 10 (L. Rezbanyai \& G. Sobrio leg.; light trap); Loderio (354 m), 19.v.1980, $10^{\star}$ (Ch. Dufour leg.). Canton Valais: Finges, 15.vii.1979, 1 के, 1 ㅇ (Ch. Dufour leg.). Canton Fribourg: Marly, 4.vi.1980, $2 \sigma^{\star}$ (W. Geiger leg.). (All MHNN; in ethanol). Canton Graubünden: Unter-Engadin, San Niclà (1050 m), 12.vii.1961, 1 o (L. \& F. Keiser leg.) [listed as laeta by Mannheims, 1964 and Starý \& Oosterbroek, 1996] (ZFMK);

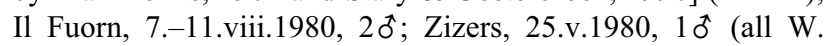
Geiger leg.) (all MHNN; in ethanol). Germany: Bayern: Ochsentobel, Kürnach, 15.vii.1971, 1 우 (H. Mendl leg.); Allgäuer Alpen, Birksau, Ringang im Stillachtal $(900 \mathrm{~m})$, 15.-18.viii.1974, 10, 30.viii.-5.ix.1974, 10, 1 우 (H. Mendl leg.; light trap) (all JSO; in ethanol). Czech Republic: Moravia: Vyšní Lhoty [6376], Morávka shores, 26.vii.1999, 1ठ,





light); Belianske Tatry Mts, Tatranská Kotlina, Belá valley [6788] (750 m), 22.vi.1975, 1ठ, 25.vi.1975, 1ठ, 26.vi.1975,

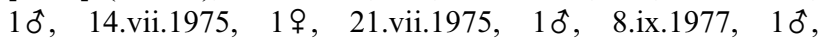
3.vii.1978, 1ठิ, 30.vi.1979, 1ठ; Brzotín [7389], Slaná shores, 13.vi.1982, 10ิ, 17.vi.1982, 10ึ; Gombasek [7488], Slaná shores, 6.vi.1979, 1ठ, 1\%; Snina, Cirocha shores [7099],

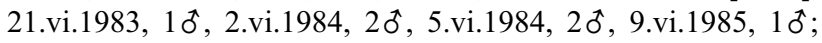
Bukovské Hills, Zboj [6900], Zbojský brook, 19.vi.1991, 1 ठิ (all J. Starý leg.) (all JSO). Austria: Tirol: Achenthal,

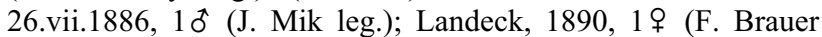
leg.) [both listed as laeta by Lackschewitz, 1940] (both NHMW). Italy: Valle d'Aosta: Entrèves, Mt. de la Saxe (1250-1350 m), 24.vii.1962, $10^{\hat{\sigma}}$ (exc. Amsterdam) (JSO). Macedonia: Gevgelia $(350 \mathrm{~m})$, 6.vii.1976, $1 \hat{\sigma}$ (W. Bestler leg.); River Markova nr. Markov-Monastir, 23.viii.1976, 1 ㅇ (M. Siebert leg.) [both listed as laeta by Mendl, 1984a] (both ZFMK; in ethanol). Albania: Kula Ljums, 7.-14.vi.1918, 2 ㅇ (H. Zerny leg.) [listed as laeta by Lackschewitz, 1940 and Mannheims, 1967] (NHMW). Bulgaria: Kalofer, 21.vi.1982, 10 (W. Krzemiński leg.); Kresna, 1.vi.1976, 1 우 (P. Lauterer leg.; in ethanol); Sandanski, Lebnitsa valley, 10.v.1989, 10 (J. Starý leg) (all JSO); Strandja Mts, Mramor (400 m), 20.vi.1980, 1 ( (H. Malicky leg.) [listed as laeta by Mendl, 1986] (ZFMK; in ethanol). Greece: Platamon, Prov. Katerini, Castle-Camping, 7.-14.vi.1968, 1 ㅇ (B. Mannheims leg.; at light); Peloponnes, Kalávryta $(750 \mathrm{~m}), 26 . v$.-16.vi.1959, 1 ô, 1 우 (H. Noack leg.) (all ZFMK); Ambelos Is. $\left(39^{\circ} 46^{\prime} / 20^{\circ} 57^{\circ}\right)(600 \mathrm{~m})$, 4.vi.1975, 
10 , 19 (H. Malicky leg.) (JSO; in ethanol). Algeria: $34 \mathrm{~km}$ NW Bouïra, Oued Isser (170 m), 19.v.1986, 1 ㅇ (P. Oosterbroek leg.) (ZMAN); Chiffy, "Monkey Valley", 18.iv.1981, 7ðే, 19.iv.1981, $3 \delta^{\widehat{ }}$ (W. Krzemiński leg.) (JSO). Azerbaijan: Diabarskaya [valley], Gasmalyan env., 16.vii.1970, 1 ㅇ (E.N. Savchenko leg.) (JSO). Russia (Asia): Kuriles, Shikotan Is., Kurilsk env., 18.viii.1976, 1 đ (V.M. Ermolenko leg.) (JSO). Japan: Shikoku, Matsuyama, 2.v.1952, 1 ㅇ (T. Ishihara leg.); Hokkaido, Sapporo, vi.1923, 10 (S. Kuwayama leg.) (both USNM). [Both specimens damaged, each with a wing mounted on a slide, added with antenna and hind leg for the specimen from Shikoku; hypopygium of the male missing. Another specimen, a female without head (USNM), with the same data as the above male, could not be identified with certainty.]

Discussion. The crucial point of the species concept of $R$. (R.) japonica, as proposed here, is the synonymy of japonica with the European hilaris and cunctans. This may be demonstrated, above all, by the size of the spermathecae and the structure of the antennae in the female holotype of $R$. japonica, supported by characters in the body colouration.

$R$. (R.) japonica, R. (R.) laeta and $R$. (R.) laetoidea $\mathrm{sp.}$ n. represent a group of closely related and exceedingly similar species. They are identical in distribution of darker markings on the thorax. In the female holotype of $R$. (R.) japonica (and two other specimens from Japan, see Material examined), these markings are dark brown, similar to the condition as described for $R$. cunctans from Europe. Such specimens with distinct dull or shiny markings on the thorax are sporadically represented in the material examined, from Sweden (holotype of cunctans), Switzerland, Germany, Italy and Algeria, and they show identity in structural characters with other specimens, paler in the pattern and more commonly collected, sometimes even at the same localities. This suggests that the variation is individual, independent of geographical distribution or ecological factors. This variation has not been observed in $R$. (R.) laeta and $R$. (R.) laetoidea sp. n., although this cannot be excluded (see note under laetoi$d e a)$. A certain type of geographical variation may also be involved in $R$. (R.) japonica. British specimens (identified as hilaris) usually have a medium-dark pattern, with the markings somewhat diffuse, suffused with grey pruinosity, whereas members of Central European populations are mostly pale, with the pattern only slightly indicated. More material would be necessary from the eastern Palaearctic to decide whether specimens with the distinct pattern on the thorax are more frequent there than they are in Europe. In any case, a male from the Kuriles (see Material examined) has the pattern considerably paler than the Japanese specimens, as much as in Central European material. Wings are described as being broad in $R$. (R.) japonica (as they are in laeta); this, however, is also subject to a certain variation. First, females always have somewhat narrower wings than males, and, second, the smaller a specimen is, the narrower wings it has relative to its own wing length.

$R$. (R.) japonica is on average the largest of the species treated here. In general appearance, if not distinguished by a dark pattern on the thorax, specimens of $R$. (R.) japonica are exceedingly similar to $R$. (R.) laeta and $R$. $(R$.) laetoidea $\mathrm{sp} . \mathrm{n}$. The latter species is distinctive by a comparatively short aedeagus and broad vesica in males and large spermathecae in females, supported by markedly narrower wings in both sexes. The differences between $R$. (R.) japonica and $R$. ( $R$.) laeta are best noticeable in the structure of the antennae, especially those of males (cf. Figs 5 and 6). In $R$. (R.) japonica, these are distinctly shorter, with the proximal flagellomeres more spherical, and the pubescence very short, subequal in length to at most half the breadth of the respective segments, distinct only on the proximal four or five flagellomeres. In $R$. ( $R$.) laeta, the antennae are longer, with the proximal flagellomeres rather oval, and the pubescence is long, subequal in length to the entire breadth of the respective segments, distinct on almost all flagellomeres. This character, together with a slightly different shape of the interbases, had been indicated by Edwards (1938: 114 , Text-figs 22e, f) as distinguishing his $R$. hilaris from $R$. laeta. Females of all the three species (japonica, laeta, laetoidea) differ in the size of the spermathecae (cf. Figs 19, 21, 23, 46-48).

Distribution. The species was reported from Japan (Hokkaido, Honshu, Shikoku, Kyushu), North Korea and the Russian Far East (Savchenko et al., 1992). There are probably no authentic literature records for Kyushu and North Korea. The synonymy with hilaris and cunctans, proposed here, extends its distribution into Europe (Great Britain, Sweden, cf. Savchenko et al., 1992) where it may also be among some records of $R$. $(R$.) laeta. Based on the material examined, the species is now recorded from Great Britain, Switzerland, Germany, Czech Republic, Slovakia, Austria, Italy, Macedonia, Albania, Bulgaria, Greece, Algeria, Azerbaijan, Russian Far East and Japan.

\section{Rhabdomastix (Rhabdomastix) laeta (Loew, 1873)}

(Figs 6, 20-21, 47)

Gonomyia laeta Loew, 1873: 60 (description).

Gonomyia laeta: Osten Sacken, 1888: 201 (faun. record); Strobl, 1901: 187 (faun. record); Strobl, 1910: 277 (faun. record); Kertész, 1903: 300 (Palaearctic catalogue); Kuntze, 1914: 371 (faun. record, key), Fig. 23 (wing); Riedel, 1918: 138 (faun. record); Riedel, 1919: 22 (faun. record); Goetghebuer \& Tonnoir, 1920: 143, 144 (faun. record, key); de Meijere, 1920: 84 (diagnosis), Tab. 10, Fig. 85 (male terminalia) [misinterpretation of figure, see lurida in Part 1]; Pierre, 1924: 107, 108 (diagnosis, key), Fig. 412 (male terminalia) [misinterpretation of figure, see lurida in Part 1]; Lackschewitz, 1927: 8 (list); Simova, 1959: 133 (faun. record).

Rhabdomastix (Sacandaga) laeta: Edwards, 1921: 209 (note); Edwards, 1926: 32 (faun. record); Starý, 1970: 44 (list); Theowald, 1971: 226 (list) [misspelling of subgenus name, see below]; Mendl, 1975: 197 (faun. record); Savchenko, 1976: 564 (faun. record); Mendl, 1977: 116 (faun. record); Mendl, 1978: 373 (list); Mendl, 1979a: 355 (faun. record); Savchenko, 1982: 276, 279 (redescription, synonymy with hilaris, faun. record, key), Figs 130/3 (wing), 131/1 (female terminalia), 135/2 (male terminalia) [misspelling of species name, see below]; Savchenko, 1983: 95 (faun. record, key); Krzemiński, 1984b: 462 (diagnosis, faun. record), Figs 53 (wing), 54-55 (male terminalia); Mendl, 1984a: 7 (faun. record) [japonica, see present revision]; Starý, 1984: 33 (faun. record); Noll, 1985: 123 (faun. record); Erhan-Dinca \& Ceianu, 1986: 89 (faun. record in list); Mendl, 1986: 278 
(faun. record) [japonica, see present revision]; Wiedeńska, 1986: 104 (faun. record); Dienske, 1987: 37 (figure only), Fig. 134 (wing); Starý, 1987: 20 (list); Reusch, 1988: 187 (faun. record); Franz, 1989: 253 (faun. record); Krzemiński \& Starý, 1989: 263 (faun. record); Mendl \& Reusch, 1989: 434, 445 (list); Reusch, 1989: 460 (faun. record); Savchenko, 1989: 266 (synonymy with hilaris, faun. record), Figs 131/2 (female terminalia), 132/2 (wing), 133/2 (male terminalia); Krzemiński, 1991: 80 (list); Wiedeńska, 1991: 57 (faun. record); Podenas, 1992: 153 (list); Savchenko et al., 1992: 315 (Palaearctic catalogue, synonymy with hilaris, tentative synonymy with cunctans and japonica); Starý \& Oosterbroek, 1996: 72 (note); Reusch \& Oosterbroek, 1997: 132 (list), Figs 97 (male terminalia), 102 (wing); Starý, 1997: 13 (list); Stubbs, 1998: 5 (synonymy with hilaris, list); Reusch, 1999: 58 (list); Pakalniškis et al., 2000: 6 (list); Reusch \& Oosterbroek, 2000: 160 (list); Podeniene, 2001: 385 (description of larva), Figs 1-4 (larva); Sidorenko, 2001: 63 (synonymy with hilaris, key).

Gonomyia (Rhabdomastix) laeta: Nielsen, 1925: 59 (diagnosis, faun. record, key); Lackschewitz, 1940: 56 [alternatively as Gonomyia (Sacandaga), faun. record], Text-fig. 1 (wing) [japonica, laeta; see present revision]; Stackelberg, 1951: 721 (faun. record).

Rhabdomastix laeta: de Meijere, 1935: 202 (faun. record); Tjeder, 1936: 135 (note); Edwards, 1938: 113, 114 (key, note), Text-figs 22c (male terminalia), 22e (male antenna); Bangerter, 1939: 485 (faun. record); Bangerter, 1946: 192 (faun. record); Tjeder, 1947: 29 (faun. record, note); Tjeder, 1948: 221 (note); Tjeder, 1955a: 227 (note); Tjeder, 1955b: 238 (list); Mannheims, 1964: 7 (faun. record); Mannheims, 1967: 473 (faun. record) [both japonica, see present revision]; Starý \& Rozkošný, 1970: 115 (faun. record); Hackman, 1980: 20 (list); Starý \& Geiger, 1998: 73 (list); Petersen \& de Jong, 2001: 151 (list).

Sacandaga laeta: Lackschewitz, 1936: 116 (note), Figs 4d, e (male terminalia).

Rhabdomastix (Secandaga) laeta: Theowald, 1971: 226 [misspelling of subgenus name, see above].

Rhabdomastix (Sacandaga) lacta: Savchenko, 1982: 279 [misspelling of species name, see above].

Diagnosis. General colouration yellow to pale yellow, with faintly indicated markings on thorax, including three stripes on prescutum. Antenna moderately long, with pubescence on flagellomeres subequal in length to breadth of respective segments. Wing broad. $A_{2}$ ending beyond origin of Rs. Legs yellow throughout. Male terminalia with apical blade of interbase rather slender and aedeagus long and slender. Female terminalia with three spherical, small spermathecae.

Redescription. Medium-sized species. Body length 5-6.5 mm, wing length 5.5-7.5 mm.

Colour. General colouration yellow to pale yellow, subshiny, with faintly indicated markings on thorax. Antenna dark brown, scape yellow. Prescutum pale yellow laterally, with indications of three broad darker stripes. Scutum and mediotergite (postscutellum) similarly darker, restrictedly patterned with yellow. Scutellum pale yellow. Pleuron mostly yellow, patterned with sulphur yellow in upper part, darker below, especially on lower portion of katepisternum and meron. Pattern on thorax generally pale, little-distinct, not varying to dark condition as in R. japonica. Wing tinged with yellowish. Halter pale yellow. Legs yellow throughout. Abdomen yellow to yellowish brown.

Head. Antenna (Fig. 6) moderately long, reaching to base of wing. Flagellomeres oval proximally, gradually narrowed and lengthened towards apex of antenna. Longest verticils on flagellomeres slightly exceeding length of their respective segments. Pubescence long, suberect, subequal in length to breadth of respective segments, distinct on almost all flagellomeres. Palpus short.

Thorax. Wing rather broad, about three times as long as broad, with comparatively short stalk. $\mathrm{Sc}_{1}$ ending before fork of Rs, at about three quarters of length of the latter. $\mathrm{Sc}_{2}$ not apparent or slightly so some distance before tip of $\mathrm{Sc}_{1} . \mathrm{R}_{3}$ about its own length or less beyond tip of $\mathrm{R}_{1} . \mathrm{R}_{4}$ with variable number of macrotrichia, but mostly with only few. $\mathrm{A}_{2}$ considerably sinuous, ending distinctly beyond origin of Rs. Halter moderately long, reaching to about posterior margin of abdominal tergite 2 .

Abdomen. Male terminalia (Fig. 20). Segment 9 broader than long. Gonocoxite comparatively long and slender. Outer gonostylus short, less than half length of gonocoxite, gently and evenly arched, somewhat broadened before apex, with small, sometimes barely distinct apical spine. Inner gonostylus generally conical. Aedeagal complex as in Fig. 20. Interbase longer and much more slender than in $R$.(R.) japonica, slightly extending beyond half length of gonocoxite, moderately expanded distally to form roughly triangular apical blade with a few microscopic teeth at distal margin. Aedeagus very long and slender, yet not as long as in $R$. (R.) japonica. Vesica comparatively small and narrow. Apodeme of vesica spine-like in dorsal aspect, subequal in length to vesica. Female terminalia (Figs 21, 47). Cercus moderately broad, slightly exceeding length of tergite 10, gently upturned. Vaginal apodeme moderately broad (much as in japonica). Spermathecae three, spherical, small, with sclerotised parts of ducts thin, subequal in length to spermathecal diameter.

Material examined. Although it seems most probable that a single specimen was dealt with in the original description (Loew, 1873: 60-62; cf. the single sex and the single size measurement), there is no statement about the number of specimens there. Hence, the type specimen examined is designated here as the lectotype to maintain the current usage of the name in case that additional specimens may be found to exist (cf. Recommendation 73F of ICZN, 1999). Lectotype $\widetilde{o}$ (present designation): Germany, Bayern, Bad Reichenhall, viii. (H. Loew leg.) (ZMHB) ["Reichenhall, wo ich sie im August fing." (Loew, 1873: 61)], labelled: "Reichh." (hand-written), "Coll. H. Loew" (printed), "8997” (printed), "Typus" (printed, red/orange), "laeta Lw." (hand-written), "Zool. Mus. Berlin" (printed, yellow). Accordingly labelled as lectotype ["Lectotype Rhabdomastix (s. str.) laeta (Loew) đิ J. Starý 2003”; printed red label]. The specimen is pinned, somewhat damaged, with left wing torn and glued to the pin; three legs present, glued; apices of left antenna and abdomen broken off. Terminalia dissected and placed in a sealed plastic tube with glycerine, pinned with the specimen.

Other material examined (114 $\widehat{\jmath}, 99+1$ specimen): Without data, 1 specimen (ơ?) ("coll. Winthem") (NHMW). Sweden: Boh.: Ljung, Anfasteröd, 26.vi.1946, 10 (B. Tjeder leg.) (JSO). Finland: EP: Kauhajoki, 2.-16.vii.2000, 1ठ, 
16.-30.vii.2000, 1 §ิ, Kauhajoki, Järvioja, 15.viii.2001, 1 đิ (J. Salmela leg.; Malaise trap) (JSJ; slides). Andorra: Vella (1000 m), 13.vi.1967, 10 (Br. Theowald leg.) (JSO). Netherlands: Gelderland: Laag Soeren, 18.-20.vi.1926, $10^{\hat{0}}$ (J. de Meijere leg.). Limburg: Houthem, 30.vii.1907, 1 t; Gulpen, 28.vii.1907, 1 ; Epen, 9.-10.vi.1904, 1 \% (all J. de Meijere leg.); Vaals, 20.vi.1960, 20ิ; Mechelen, 20.vi.1960, 1 ơ (all Br. Arnoud leg.). (All ZMAN). Switzerland: Canton Genève: Croix-de-Rozon, 9.-15.vii.1979, 10ิ, 6.-12.viii.1979, 1 우 (Ch. Dufour \& W. Geiger leg.; Malaise light trap). Canton Ticino: Cadenazzo (203 m), 25.vi.-15.vii.1979, 2 đ (Ch. Dufour \& W. Geiger leg.; Malaise light trap); Gordevio, early vii.- early viii.1980, 4 우 (L. Rezbanyai leg.; Malaise light trap); Gudo Demanio (210 m), middle viii.1980, 19 (L. Rezbanyai \& G. Sobrio leg.; light trap). Canton Valais: Dixence, 30.vii.1979, $1 \hat{\sigma}^{\hat{\sigma}}$ (collector unknown; light trap). (All MHNN; in ethanol). Germany: Hessen: Breitenbach nr. Schlitz, 17.vi.-29.vii.1970, 20, 6우 (J. Illies leg.); Schlitz, 12.vi.-23.vii.1971, 1 ô, 3 ㅇ (V. Puthz leg.); Schlitz, Rohrwiesenbach, 19.vi.1970, 10, 19.vi.-8.viii.1970, $5 \hat{\jmath}, 79$ (J. Illies leg.), 2.vi.-2.viii.1971, 60, 2 우 (Sandrock leg.), 10.vi.-29.vii.1971, 19ð, 15 ㅇ (J. Illies leg.) (all JSO; in ethanol); Sengelbach nr. Schlitz, 25.vi.-17.viii.1973, 3 đే, 3 우 (J. Illies leg.) (ZFMK; in ethanol). Bayern: Kreuzthal, Kreuzbach, 30.vi.-18.viii.1971, 60, 5 $q$, 12.vii.-24.viii.1972, $13 \%$ (light

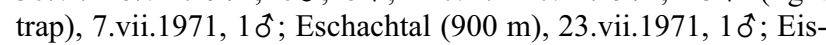
tobel nr. Ebratshofen, 9.viii.1971, 1ठ; Obergünzburg, 29.-31.vii.1974, 1 ㅇ (at light); Kempten (shop window), 13.vii.1971, 1 9 ; Allgäuer Alpen, Birksau, Ringang im Stillachtal $(900 \mathrm{~m}), 6 .-9.1 x .1973,10$ (light trap) (all H. Mendl leg.). (All JSO; in ethanol). Czech Republic: Bohemia: Klášterec nr. Vimperk [6948], Arnoštský brook, 6.vii.2003, 20, 1 (J. Starý leg.) (JSO). Moravia: Velké Losiny [5968], 13.vii.1977, 220ิ, 8\%; 25.vii.1978, 2\%; Libavá env., Údolná [6371], Odra valley, 31.vii.1996, 1\%; Hostýnské Hills, "Valaška" [6672] (500-600 m), 23.vii.1992, 10े, 1 ㅇ (all J. Starý leg.) (all JSO). Slovakia: Šaštín [7368] (distr. Senica), 23.vi.1979, 10ิ,1 1 ; Trstená [6683], “Jelešňa”, 10.vii.1988, 1 đ; Beňadovo [6582], Mútňanka shores, 7.vii.1988, 20ิ; Chočské Hills, Kvačianska valley [6783], 23.vii.1998, 20ิ, 2क; Západné Tatry Mts, Oravice, Tichá dolina [valley] [6784] $(800 \mathrm{~m})$, 17.viii.1999, 1ठ; Belianske Tatry Mts, Tatranská Kotlina, Belá valley [6788] (750 m), 5.ix.1977, 1q; Hranovnica [7087], Hornád shores, 1.vii.1979, 40ิ, 1\%; Pol'ana Mts, Kyslinky [7382], Hučava valley $(750 \mathrm{~m}), 20 . v i .2003,10$; Pol'ana Mts, Čierny Potok, [7383] (700 m), 3.vii.2000, 20, 2ㅇ, 4.vii.2000, 2ㅇ, 6.vii.2000, $2 \hat{0}, 7 . v i i .2000,1 \hat{0}, 4$ \% , 8.vii.2000, 2 우 (all at light); Pol'ana Mts, "Hronček ponds" [7383] (650 m), 10.vi.1999, 1 ô, 6.ix.2001, 10; Gombasek [7488], Slaná shores, 5.vi.1979, 1ठ, 6.vi.1979, 1ठ; Snina, Cirocha shores [7099], 8.vi.1985, 1 \%; Stakčín, Chotinka valley [6999], 22.vi.1983, 1 đే; Bukovské Hills, Nová Sedlica env. [6901], 9.vii.1993, 1 ơ (all J. Starý leg.) (all JSO). Austria: Niederösterreich: Wienerwald, $1 \delta^{\widehat{T}}$ (J. Bischof leg.). Kärnten: Dobratsch [Döbriach], vii.1874, 1 ㅇ (Bergenstamm leg.). (All NHMW). Italy: Piemonte: Carmagnola, Gerbasso, Greto F. Po (232 m), 15.ix.2000, 1 ㅇ (G.B. Delmastro leg.) (JSO; dried from ethanol). Slovenia: Kamniska Bistrica (600 m), 30.vi.1968, 1 ㅇ (F. Hartig leg.) (ZFMK). Bulgaria: Kalofer, 21.vi.1982, 10 (W. Krzemiński leg.); Sandanski, 14.vi.1984, 1 đ̊ (W. Krzemiński leg.); Sandanski, Lebnitsa valley, 6.v.1989, 1 ơ, 10.v.1989, 1 ㅇ (J. Starý leg.) (all JSO). Ukraine: Zakarpatskaya oblast: Svidovetskiy [mountain ridge], Chernotisskoe [forest area], 1.vii.1975, 10, 2 우 (E.N. Savchenko leg.) (JSO).

Discussion. No conspicuous variation was observed in $R$. (R.) laeta, except that the size of specimens varies extensively, both locally and geographically (specimens from North Europe appear to be generally smaller).

$R$. (R.) laeta is very similar to pale specimens of $R$. (R.) japonica, differing in the structure of the antennae and the male and female terminalia. For details, see Figs 5-6, 17, 19-21, 46-47 and the discussion of $R$. (R.) japonica.

Distribution. As one of those most commonly treated in the literature, the species was recorded from many European countries, also from West Siberia (Altai) and Mongolia (Savchenko et al., 1992). Although it most probably does occur throughout Europe, the actual records are unreliable because it could have been confused with $R$. (R.) japonica or $R$. (R.) laetoidea $\mathrm{sp} . \mathrm{n}$. Based on the material examined, the species is confirmed in Europe for Sweden, Finland, Netherlands, Switzerland, Germany, Czech Republic, Slovakia, Austria, Slovenia, Bulgaria and Ukraine, and newly recorded for Andorra and Italy. [The record from Italy by Mannheims (1964), originally accepted by Savchenko et al. (1992), refers to a Swiss locality (cf. Starý \& Oosterbroek, 1996) and represents japonica (cf. present revision)]. Not confirmed from Great Britain (see japonica), Belgium, France, Denmark, Poland, Lithuania, Latvia, Estonia, Bosnia and Hercegovina, Macedonia, Albania, Romania and European Russia.

\section{Rhabdomastix (Rhabdomastix) laetoidea sp. $\mathbf{n}$.}

(Figs 2, 22-23, 48)

Rhabdomastix (Sacandaga) sp. cf. laeta: Savchenko, 1982: 276, 280 (diagnosis, tentative synonymy with japonica, faun. record, key), Fig. 130/4 (wing); Savchenko, 1989: 266 (tentative synonymy with japonica, faun. record, note), Fig. 232/3 (wing).

Diagnosis. General colouration yellow to pale yellow, with faintly indicated markings on thorax, including three stripes on prescutum. Antenna moderately long, with pubescence on flagellomeres subequal in length to breadth of respective segments. Wing narrow. $\mathrm{A}_{2}$ ending shortly beyond origin of Rs. Legs yellow throughout. Male terminalia with apical blade of interbase lanceolate and aedeagus short and broad. Female terminalia with three spherical, large spermathecae.

Description. Medium-sized to small species. Body length 4-7 mm, wing length 4.5-7.5 $\mathrm{mm}$.

Colour. General colouration yellow to pale yellow, subshiny, with less distinct markings on thorax, compared to $R$. japonica and $R$. laeta, however, practically identical to the latter species in distribution of pattern. Antenna dark brown, scape yellow. Wing tinged with yellowish. Halter pale yellow. Legs yellow throughout. Abdomen yellow.

Head. Antenna moderately long, reaching to base of wing. Flagellomeres oval proximally, gradually narrowed and lengthened towards apex of antenna. Longest verticils on flagellomeres slightly exceeding length of their respective segments. Pubescence long, suberect, subequal in length to breadth of respective segments, distinct on almost all flagellomeres. Palpus short.

Thorax. Wing (Fig. 2) narrow, compared to both $R$. japonica and $R$. laeta, about four times as long as broad, with stalk longer than in two latter species. $\mathrm{Sc}_{1}$ ending just beyond mid-length of Rs. $\mathrm{Sc}_{2}$ slightly apparent, shortly before tip of $\mathrm{Sc}_{1} . \mathrm{R}_{3}$ about its own length beyond tip of $R_{1}$. $R_{4}$ with numerous macrotrichia both dorsally 
and ventrally. $\mathrm{A}_{2}$ slightly sinuous, ending shortly beyond origin of Rs. Halter moderately long, reaching to about posterior margin of abdominal tergite 2 .

Abdomen. Male terminalia (Fig. 22). Segment 9 broader than long. Gonocoxite not as long as in $R$. $(R$. japonica and $R$. (R.) laeta. Outer gonostylus short, less than half length of gonocoxite, gently and evenly arched, somewhat broadened before apex, with small, sometimes barely distinct apical spine. Inner gonostylus generally conical. Aedeagal complex as in Fig. 22. Interbase subequal to half length of gonocoxite, with apical blade more or less lanceolate, more slender than in $R$. (R.) laeta. Aedeagus comparatively short and broad, subequal in length to vesica, the latter rather broad. Apodeme of vesica spine-like in dorsal aspect, shorter than vesica. Female terminalia (Figs 23, 48). Cercus moderately broad, slightly exceeding length of tergite 10 , gently upturned. Vaginal apodeme narrow, compared to $R$. $(R$.) japonica and $R$. (R.) laeta. Spermathecae three, spherical, larger and paler than those of latter two species, with sclerotised parts of ducts thin, subequal in length to spermathecal diameter.

Material examined. Holotype $\delta$ : Czech Republic, Moravia, Hrubá Voda nr. Olomouc [6370], 14.vi.1977 (J. Starý leg.) (SMOC). The specimen is glued onto a triangular cardboard point, without both hind legs and apex of abdomen. Terminalia dissected and placed in a sealed plastic tube with glycerine, pinned with the specimen. Paratypes $(163 \hat{\sigma}, 40 \%)$ : Czech Republic: Bohemia: Malenice [6849] (distr. Strakonice), Volyňka shores, 5.viii.1993, 1우, 6.viii.1994, 1 đ, 20.viii.1996, 20ิ, 5.vii.2003, $2 \widehat{0}$ (J. Starý leg.) (JSO). Moravia: Jeseníky Mts, Branná [5868] (700 m), 17.vii.1973, 50ิ, 1 ㅇ (J. Starý leg.); Bělá - Domašov [5869], Bělá valley, 15.vii.1975, 5 ơ (J. Martinovský leg.); Malá Morávka [5969], Moravice shores, 28.viii.1997, 20; Velké Losiny [5968], 10.viii.1977, 10, 13.vii.1977, 1 ㅇ (all J. Starý leg.); Valšov [6070], Moravice valley, 21.vi.1970, 3ठิ, 27.vi.1970, 1ठ (J. Martinovský leg.), 7.vii.1982, 60ิ, 4.viii.1982, 10ิ, 1우, 1.vi.1983, 10ิ, 3.vii.1984,

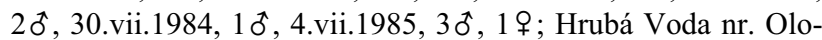
mouc [6370], 27.vi.1970, 10ðే, 30.vi.1970, 4ठ, 1우, 8.vi.1971,

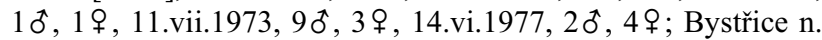
O. [6378], Olše shores, 26.vi.1997, 60, 11.vi.1998, 2 đે; Vyšní Lhoty [6376], Morávka shores, 6.vi.1997, 19, 3.vi.1998, 20, 10.vi.1998, 1 q (all J. Starý leg.) (all JSO). Slovakia: Beňadovo [6582], Mútňanka shores, 7.vii.1988, 20ิ, 1 \%; Západné Tatry Mts, Oravice, Tichá dolina [valley] [6784] $(800-850 \mathrm{~m})$, 17.viii.1999, 10ત, 15.vi.2000, 3 đ̊ (all J. Starý leg.); Belianske Tatry Mts, Tatranská Kotlina [6788] (750 m), Belá valley,

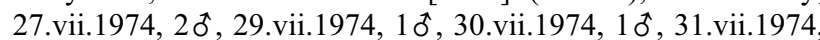
5ठ, 1 ㅇ (J. Starý leg., 1 đ J. Martinovský leg.), 21.vi.1975, 7 ठૈ, 22.vi.1975, 1 ठิ (J. Starý leg.), 23.vi.1975, 2 ठิ (J. Martinovský

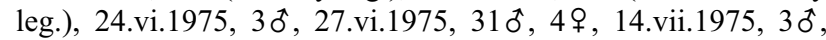
15.vii.1975, 1ㅇ, 22.vii.1975, 1ㅇ, 18.vi.1977, 10, 5.viii.1999, 10ิ; Hranovnica [7087], Hornád shores, 1.vii.1979, 10ิ, 19 ; Očová nr. Zvolen [7381], Hučava valley, 17.vi.2003, 10, 2q; Pol'ana Mts, Kyslinky [7382], Hučava valley $(750 \mathrm{~m})$, 16.vi.2003, 8ठิ 20.vi.2003, $2 \widehat{0}, 1$ \% ; Pol'ana Mts., Čierny Potok [7383] $(700 \mathrm{~m})$, 8.vii.2000, 1ठ; Pol'ana Mts, Hronček valley [7383] (700 m), 12.vi.1999, 10 ; Pol'ana Mts, "Hronček ponds" [7383] (650 m), 10.vi.1999, 1 \% , 7.vii.2000, 1 \%; Snina, Cirocha shores [7099], 19.vi.1983, 19; Stakčín, Chotinka valley [6999], 22.vi.1983, 1ठิ , 6.vi.1985, 10ิ, 1\%; Bukovské Hills, Ruský Potok [6900], 10.vi.1985, 1\%; Bukovské Hills, Krivé [7000],
Zbojský brook, 17.vi.1991, 20ิ, 2क; Bukovské Hills, Ubl’a [7100], Stežná shores, 23.vi.1983, 1ठ, Kosmatec, 23.vi.1983, 20 (all J. Starý leg.) (all JSO, SMOC). Bulgaria: Rodopi Mts, Bachkovo, 20.vi.1982, $1 \delta^{\Uparrow}$ (W. Krzemiński leg.); Yavorov nr. Kresna, 14.vi.1990, 2 \%; Sandanski, Lebnitsa valley, 12.vi.1990, 10; Pirin Mts, Lilianovo nr. Sandanski, 15.vi.1990, 10, 1 \% 17.vi.1990, 1\%; Pirin Mts, Bansko env., 23.vii.1987, 20 , 1 ㅇ (all J. Starý leg.) (all JSO). Ukraine: Zakarpatskaya oblast: Svidovetskiy [mountain ridge], Chernotisskoe [forest area], 1.vii.1975, 1 ơ (E.N. Savchenko leg.) (JSO).

Etymology. The name of the new species, laetoidea, indicates its close relationship to $R$. (R.) laeta. An adjective in nominative singular.

Discussion. The new species differs from both $R$. $(R$.) japonica and $R$. (R.) laeta by its generally smaller size and distinctly narrower wings in both sexes. The latter character is correlated with the venation in that the veins run closer to each other and $\mathrm{A}_{2}$ is less sinuous, ending only shortly beyond the origin of Rs (Fig. 2). In $R$. (R.) laetoidea sp. n., the male terminalia are especially distinctive by having a comparatively short and broad aedeagus and a broad vesica (Fig. 22) (long and slender in japonica and laeta, cf. Figs 17, 20). The female terminalia are characterised by large spermathecae (Figs 23, 48) (smaller in japonica and laeta, cf. Figs 19, 21, 46-47).

Distribution. Czech Republic, Slovakia, Bulgaria, Ukraine.

Note. This may be Rhabdomastix (Sacandaga) shardiana Alexander, 1957 described from a single male from Pakistan (Alexander, 1957: 292) [holotype ơ: North West Frontier Province, Shardi, 1.-10.viii.1953, altitude 6,130 feet, (F. Schmid leg.) (USNM)], a species with a rather distinct pattern on the thorax, generally conforming the condition in the laeta complex. Due to distortion of the male terminalia mounted on a slide, absence of the antennae in the holotype, and considering the disjunct occurrences of $R$. (R.) laetoidea $\mathrm{sp}$. n. and R. shardiana, a clear decision on the conspecifity of the two forms could not be reached. Therefore, it is preferred to describe here $R$. (R.) laetoidea sp. n., a species fairly common in Central and South Europe, until more material, including females, is available from the area relevant to $R$. shardiana.

\section{Rhabdomastix (Rhabdomastix) borealis Alexander, 1924}

(Figs 24-26, 49)

Rhabdomastix (Sacandaga) borealis Alexander, 1924a: 9 (description).

Rhabdomastix (Sacandaga) borealis: Alexander, 1965: 77 (Nearctic catalogue)

Rhabdomastix (Sacandaga) sp. (? borealis): Savchenko, 1978a: 66 (faun. record).

Rhabdomastix lapponica Tjeder, 1936: 133 (description), Figs 2 (wing), 3a-e (male terminalia). - syn. n.

Rhabdomastix lapponica: Edwards, 1938: 113 (synonymy with infuscata, key), Text-fig. 22d (male terminalia); Tjeder, 1955b: 238 (list).

Rhabdomastix (Sacandaga) lapponica: Mendl, 1978: 373 (list); Mendl, 1979b: 23 (faun. record); Savchenko \& Parkhomenko, 1980: 104, 106 (tentative synonymy with borealis, faun. record); Mendl, 1984b: 14 (faun. record); Lantsov \& Chernov, 1987: 33 (faun. record); Savchenko, 1989: 266 (tentative synonymy with borealis, faun. record); Savchenko et al., 1992: 315 (Palaearctic catalogue, synonymy with infuscata, tentative synonymy with borealis); Reusch \& Ooster- 
broek, 1997: 132 (list), Fig. 96 (male terminalia); Sidorenko, 2001: 63 (note).

Sacandaga infuscata Lackschewitz, 1936: 116 (description), Figs $4 a-c$ (male terminalia).

Diagnosis. General colouration yellowish brown, patterned with dark brown and pale yellow on thorax. Antenna moderately long, with pubescence on flagellomeres very short. Wing moderately broad. $\mathrm{A}_{2}$ ending beyond origin of Rs. Legs with femora considerably darkened distally. Male terminalia with apical blade of interbase triangular provided with tooth at outer margin, and aedeagus long. Female terminalia with three spherical spermathecae, somewhat smaller than those of $R$. (R.) laetoidea sp. $\mathrm{n}$.

Redescription. Medium-sized species. Body length 4-7.5 mm, wing length 5-8 mm.

Colour. General colouration yellowish brown, with slight greyish pruinosity, patterned with dark brown and pale yellow on thorax. Antenna dark brown, scape yellowish brown. Prescutum dark brown, yellowed laterally. Sometimes two yellow longitudinal lines apparent, demarcating three broad dark brown stripes; yellow patch near posterior margin of prescutum. Scutum dark brown, patterned with yellow medially. Scutellum mostly yellow. Mediotergite (postscutellum) yellow anteriorly, dark brown in posterior half. Pleuron yellowish brown to brown, with slight greyish pruinosity, patterned with pale yellow in upper part, darkened on lower portions of katepisternum and meron. Wing tinged with brownish. Coxae yellowish brown. Trochanters and bases of femora yellow, the latter considerably darkened distally. Rest of legs yellowish brown. Halter pale yellow. Abdomen greyish brown.

Head. Antenna moderate in length, reaching to about base of wing. Proximal three or four flagellomeres shortoval to nearly spherical, following ones gradually narrowed and lengthened towards apex of antenna. Longest verticils on flagellomeres slightly exceeding length of their respective segments. Pubescence very short, suberect, distinct only on proximal four or five flagellomeres (much as in japonica). Palpus short.

Thorax. Wing moderately broad, more than three times as long as broad, with stalk comparatively short. $\mathrm{Sc}_{1}$ ending before fork of Rs, at about three quarters of length of the latter. $\mathrm{Sc}_{2}$, if apparent, considerably retracted from tip of $\mathrm{Sc}_{1}$, approximately opposite half length of $\mathrm{Rs}$ (much as in japonica). $\mathrm{R}_{3}$ less than its own length beyond tip of $R_{1}$. $R_{4}$ with a few macrotrichia both dorsally and ventrally. $A_{2}$ considerably sinuous, ending distinctly beyond origin of Rs. Halter moderately long, reaching to about posterior margin of abdominal tergite 2 .

Abdomen. Male terminalia (Fig. 24). Segment 9 broader than long. Gonocoxite comparatively long and slender. Outer gonostylus short, less than half length of gonocoxite, gently and evenly arched, parallel-sided, with small apical spine. Inner gonostylus generally conical, slender distally. Aedeagal complex as in Fig. 24. Interbase very long, considerably extending beyond half length of gonocoxite and expanded before apex to form roughly triangular apical blade terminating in large acute tooth at outer margin (at margin closer to long axis of hypopygium for crossing interbases). Aedeagus long (not as slender as in japonica and laeta), nearly twice length of vesica or less, the latter comparatively small and narrow. Apodeme of vesica spine-like in dorsal aspect, short, about half length of vesica. Female terminalia (Figs 25-26, 49). Cercus moderately broad, slightly exceeding length of tergite 10, gently upturned. Vaginal apodeme abruptly expanded into very broad, transversally oblong or semicircular distal (caudal) portion. Spermathecae three, spherical, somewhat smaller than those of $R$. (R.) laetoidea sp. n., with sclerotised parts of ducts thin, shorter than spermathecal diameter.

Material examined. Rhabdomastix (Sacandaga) borealis: Holotype ơ (monotypy): USA, Alaska, Hurricane, 15.vii.1921 (J.M. Aldrich leg.) (USNM), labelled: "Hurricane Alaska VII-15.21" (partly printed), "JMAldrich coll." (printed), "Holotype Rhabdomastix borealis C.P. Alexander" (partly printed, red). The specimen is pinned, without left wing, abdomen, fore left and both hind legs. The wing mounted on a slide, labelled with the same data, with the inscription "Holotype 2290". Terminalia dissected and placed in a sealed plastic tube with glycerine, pinned with the specimen.

Rhabdomastix lapponica: In the original description (Tjeder, 1936: 135), the male holotype and an unspecified number of paratypes are mentioned. At present, 4 paratypes are deposited in MZLU; holotype could not be located (R. Danielsson, e-mail comm.). However, there is no doubt about the conspecifity of the type series, and an examination of a paratype appears sufficient. Paratype đ: Sweden, Lappland, Abisko, 29.vii.1918 (O. Ringdahl leg.) (MZLU), labelled: “Abisko 29.7.-18” (partly printed), "Rhabdomastix lapponica Tjed. Paratypus $\boldsymbol{\delta}^{\star} "$ (handwritten) and "Paratypus" (printed, red). The specimen, in relatively good condition, is micro-pinned on a celluloid slide, with both fore legs and right hind leg attached, another leg glued onto the celluloid slide; apex of abdomen cut off. Terminalia dissected and placed in a plastic tube with glycerine, pinned with the specimen.

Sacandaga infuscata: Holotype ơ (monotypy): Sweden, Lappmark, Abiskojokk, 26.vii.1926 (O. Ringdahl leg.) (MZLU), labelled: "Abiskoj. 26.7-26" (partly printed, some hand-written numerals smeared), "Sac. infuscata nov. sp. det. Lacksch." (printed), a small blank red paper square and "Rhabdomastix lapponica Tjed. det. Bo Tjeder (pencil, in Tjeder's hand). Accordingly labelled as holotype ("Holotype Sacandaga infuscata Lackschewitz o J. Starý 2003", printed, red label). The specimen is pinned, with only femur of right fore leg attached; apices of left wing and abdomen broken off. Terminalia dissected and preserved in Canada balsam between celluloid slides, pinned with the specimen. Interbases are somewhat mis-shapen in this preparation, as shown in the original description (Lackschewitz, 1936, Figs 4a,b,c), they, nevertheless, are exactly as in Fig. 24.

Other material examined $(22 \hat{\sigma}, 7 q)$ : Norway: Nordvaranger, Skonsvikelv nr. Berlevåg, 25.vii.1976, 19ð, $5 q$ (W. Tobias leg.) (2犬, 19 in JSO; rest in ZFMK; all in ethanol). Sweden: Torneträsk nr. Abisko, 3.viii.1975, 2 ㅇ (H. Mendl leg.) (JSO, ZFMK; in ethanol). Russia (Asia): Chukotka, Beringovskiy, 25.vii.1978, 20 (S.I. Parkhomenko leg.); Kuriles, Paramushir Is., Severo-Kurilsk, 27.viii.1976, 10 (V. M. Ermolenko leg.) (all JSO). Canada: [a slide, with two wings, identi- 
fied by Alexander as borealis, labelled “... Canad. N.W. Ter. / Aklavik / July 20, 1931 / (O. Bryant ...)”(USNM)].

Discussion. The shape of the vaginal apodeme and the size of the spermathecae in the female holotype of $R$. borealis, supported by external characters, prove unambiguously the synonymy of borealis and lapponica.

Although clearly belonging to the species complex comprising the three species above (japonica, laeta, laetoidea), $R$. ( $R$.) borealis is very distinctive in both general appearance and the structure of the male terminalia. Its general colouration is distinctly darker, yellowish brown, with greyish pruinosity, patterned with dark brown on the thorax, extensively so dorsally. In contrast to the species above, the femora are considerably darkened distally in $R$. $(R$.) borealis (yellow throughout in japonica, laeta and laetoidea). Within the species treated here, the male terminalia of $R$. (R.) borealis are unique in the shape of the interbases (Fig. 24). The female terminalia are similar to those of the related species, with the spermathecae somewhat smaller than in $R$. (R.) laetoidea sp. n., although they are well characterised by a very broad vaginal apodeme (Fig. 25).

Distribution. In the new concept presented here, the species appears to be Holarctic in distribution, and was recorded from the USA (Alaska) (Alexander, 1965), Norway, Sweden and the Russian Far East (Savchenko et al., 1992). Herewith confirmed for all the countries. Distribution in Canada is practically beyond any doubt, but not proved by the two wings on the slide tentatively listed here. The identification by Alexander, who must have had the rest of the specimen, is reliable insofar as made possible by a comparison of external characters. In any case, an authentic record for Canada is needed. A short diagnosis of Gonomyia schistacea from Finland by Lundström (1907: 21), added with a figure of the wing showing $R_{3}$ less than its own length beyond the tip of $\mathrm{R}_{1}$ (cf. Lundström, 1907, Fig. 25 ), suggests that a species of the laeta complex is involved, most probably $R$. (R.) borealis. This, however, should also be confirmed.

\section{Rhabdomastix (Rhabdomastix) edwardsi Tjeder, 1967}

(Figs 27-29, 50)

Rhabdomastix parva: Edwards, 1938: 113, 115 (diagnosis, conspecific with schistacea sensu Loew, Verral nec Schummel, faun. record, key), Text-figs $21 \mathrm{~b}-\mathrm{d}$ (wing), 22e (male terminalia) [misinterpretation, see Tjeder, 1964: 146, 1967: 225]; Coe 1950: 52 (key), Fig. 23c (male terminalia) [misinterpretation]; Rotheray \& Robertson, 1993: 17 (faun. record) [misinterpretation].

Gonomyia (Rhabdomastix) schistacea: Lackschewitz, 1940: 56 [alternatively as Gonomyia (Sacandaga), faun. record] [partim, see present revision].

Rhabdomastix schistacea: Mannheims, 1967: 473 (faun. record) [see present revision].

Rhabdomastix edwardsi Tjeder, 1967: 225 (description, conspecific with parva sensu Edwards nec Siebke), Figs 1 (wing), 2-6 (male terminalia), 7-10 (female terminalia).

Rhabdomastix edwardsi: Hutson \& Vane-Wright, 1969: 248 (conspecific with parva auctt nec Siebke, schistacea auctt nec Schummel); Godfrey, 2001: 21, 23 (faun. record).

Rhabdomastix (Sacandaga) edwardsi: Mendl, 1973b: 3 (note); Mendl, 1978: 373 (list); Dienske 1987: 36 (figure only), Fig. 130 (male terminalia); Starý, 1987: 20 (list) [deleted; see Starý, 1993: 123, 1996: 119]; Savchenko et al., 1992: 315
(Palaearctic catalogue); Stubbs, 1998: 5 (conspecific with parva sensu British authors nec Siebke, list).

Rhabdomastix (Sacandaga) subparva: Mendl, 1984a: 7 (faun. record) [partim, see present revision].

Diagnosis. General colouration dark greyish brown, with bluish pruinosity on pleuron. Antenna short. Wing narrow, infuscated. $\mathrm{A}_{2}$ ending before origin of Rs. Legs brown with coxae greyish brown. Male terminalia with outer gonostylus generally straight, with distinct apical spine, and apical blade of interbase spoon-shaped. Female terminalia with three spherical, small spermathecae.

Redescription. Small species. Body length $4-6 \mathrm{~mm}$, wing length 4-6.5 mm.

Colour. General colouration dark greyish brown with bluish tinge, dull, without conspicuous markings on thorax, more brownish in middle of prescutum. Antenna dark brown throughout. Pleuron heavily suffused with dark bluish grey pruinosity, somewhat variable in extent and bluish hue. Wing infuscated. Halter whitish. Coxae generally dark, brown to greyish brown. Trochanters and bases of femora yellowish brown, the latter darkened distally. Rest of legs generally brown. Abdomen dark greyish brown.

Head. Antenna short, not reaching to base of wing. Flagellomeres short-oval. Longest verticils on flagellomeres slightly exceeding length of their respective segments. Pubescence indistinct. Palpus short.

Thorax. Wing rather narrow, about four times as long as broad, with stalk comparatively short. $\mathrm{Sc}_{1}$ ending before half length of $\mathrm{Rs}$. $\mathrm{Sc}_{2}$ lacking. $\mathrm{R}_{3}$ more than its own length beyond tip of $\mathrm{R}_{1} . \mathrm{R}_{4}$ bare or with at most a few macrotrichia dorsally. $A_{2}$ sinuous, ending before origin of Rs. Halter comparatively short, not reaching to posterior margin of abdominal tergite 2 .

Abdomen. Male terminalia (Fig. 27). Segment 9 longer than broad. Gonocoxite sometimes rather stout, broad. Outer gonostylus comparatively short, about half length of gonocoxite, bent only at base, straight distally, generally parallel-sided, with distinct apical spine. Inner gonostylus generally conical. Aedeagal complex as in Fig. 27. Interbase moderate in length, reaching to about half length of gonocoxite, very slender near mid-length, at most very slightly bent distally to form spoon-shaped apical blade, mostly rounded at apex (pointed in some cases, cf. Fig. 27). Aedeagus slender, subequal in length to vesica, the latter broad, bulbous, with long apodeme, narrowly fan-shaped in dorsal aspect, about same length as vesica. Female terminalia (Figs 28-29, 50). Cercus comparatively slender and rather long, longer than tergite 10 , gently upturned. Spermathecae three, small, spherical, with sclerotised parts of ducts very short. One spermatheca sometimes smaller than other two.

Material examined. Holotype $\$$ (original designation): Great Britain, England, South Devon, Sidmouth, 10.v.1936 (F.W. Edwards leg.) (BMNH), labelled "S. Devon: Sidmouth. 10.V.1936. F.W. Edwards. B.M. 1936-366" (printed), "Holotype" (a red-margined circular label, printed), "Holotypus $q$ Rhabdomastix edwardsi Tjed. Bo Tjeder 1966" ("Holotypus" printed, the rest in Tjeder's hand, red label). The specimen is micro-pinned on a celluloid slide, with only left fore and hind 


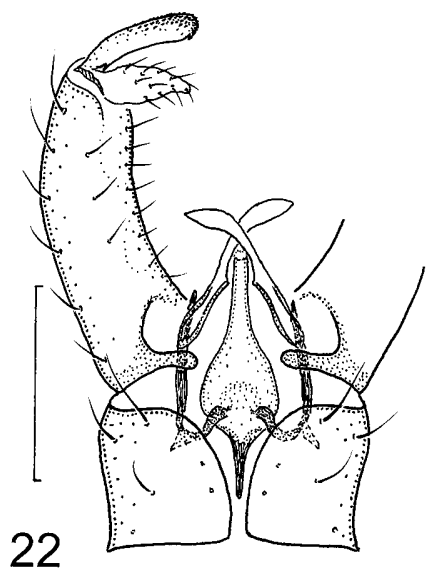

22

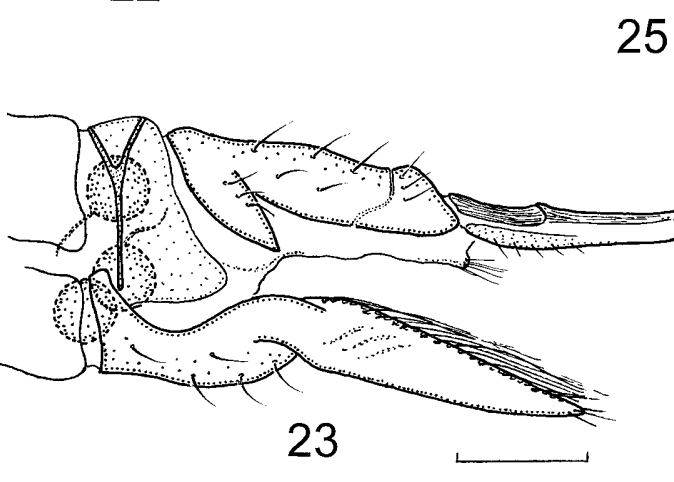

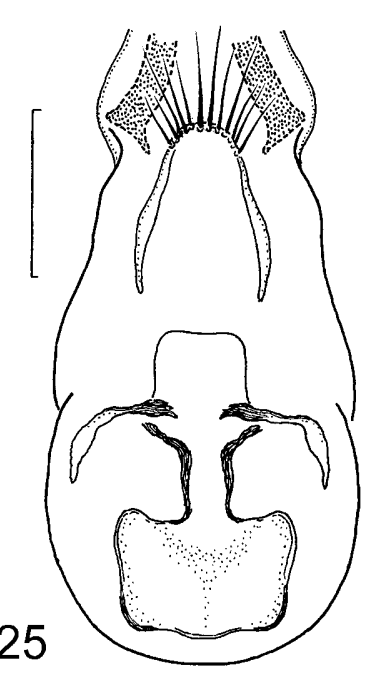
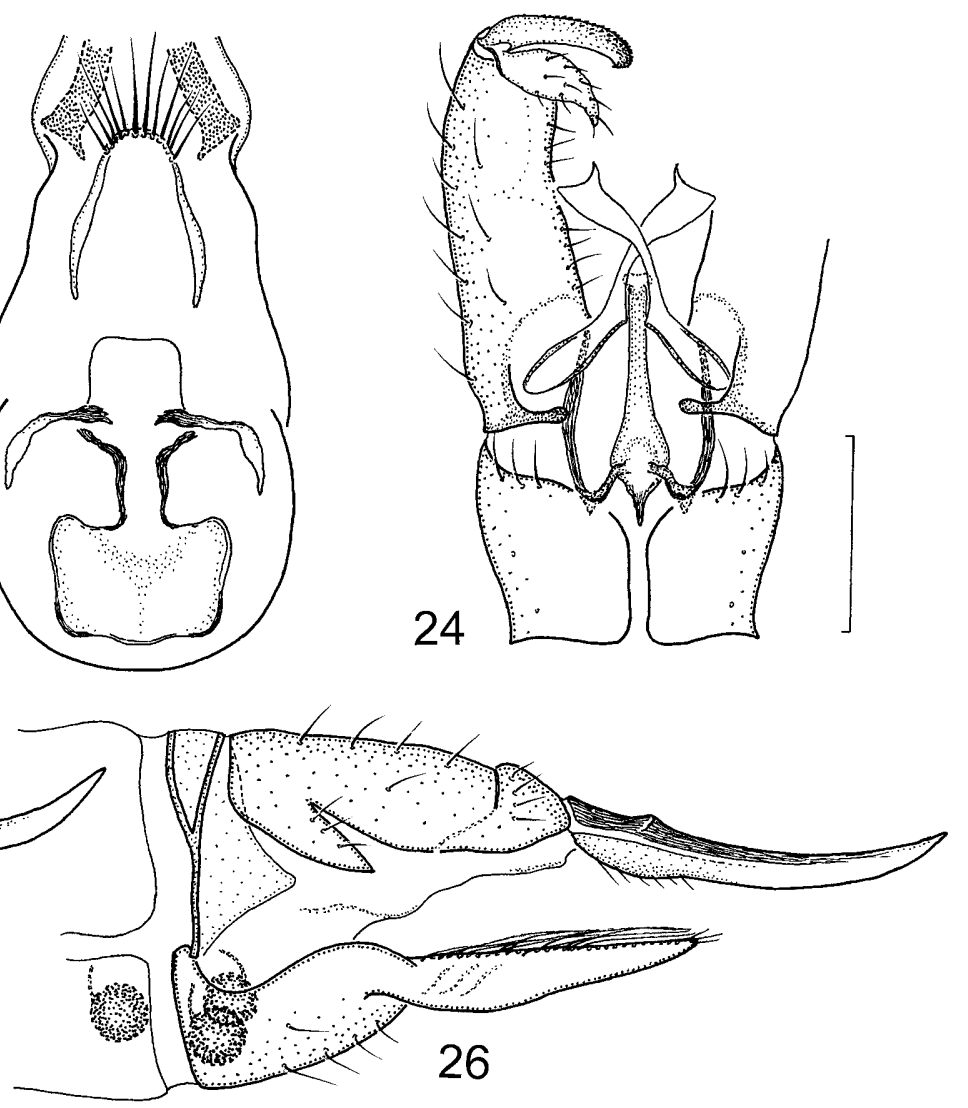

Figs 22-26. 22-23. Rhabdomastix (Rhabdomastix) laetoidea sp. n. (ơ: holotype; \$: paratype, Czech Republic: Hrubá Voda nr. Olomouc). 22 - male terminalia, general view, dorsal; 23 - female terminalia, general view, lateral. 24-26. $R$. (R.) borealis Alexander, 1924 (Norway: Nordvaranger). 24 - male terminalia, general view, dorsal; 25-26 - female terminalia, internal structures, ventral (25) and general view, lateral (26). Scale bars $0.25 \mathrm{~mm}$.

legs missing; right wing and apex of abdomen broken off, the former glued onto the celluloid slide. Terminalia dissected and preserved in a hyaline medium between plastic slides, pinned with the specimen. Paratypes: Great Britain: Scotland: Perthshire, Killin distr., Ben Chalum $(800-2500 \mathrm{ft})$, 9.-10.vi.1932, 10; Perthshire, Glen Lyon, undated, 19 (both F.W. Edwards leg.) (both MZLU); Dunbartonshire, Luss, 3.vi.1911, 1 ㅇ (J.J.F.X. King leg.) (BMNH). England: Yorkshire, Coverham, 23.vi.1924, 10, 19 (F.W. Edwards leg.); Herefordshire, Cusop Dingle, 29.vi.1899, 1 đ (J.H. Wood leg.) (all BMNH). All paratypes examined by me in 1970's.

Other material examined $(231 \delta, 103 q)$ : Great Britain: Scotland: Inverness-shire, river through Uruqubart Wood, 14.vii.1991, 10 (A.E. Stubbs leg.); Perthshire, Angus, R. Isla, Den of Airlie, 4.vii.1977, $10^{\text {A }}$ (A.M. Hutson leg.) (both JSO); Aberdeenshire, Braemar, Mar Lodge Estate, Upper Quoich, 7.vii.2000, 9ठ, 5 (pitfall \& water traps); Braemar, River Dee downstream of White Badge, 28.vi.2000, $5 \hat{\delta}$ (all A. Godfrey leg.) (1 $\hat{\delta}, 2+$ dried from ethanol, JSO; rest in ethanol, AGB). Wales: Brecknockshire, Brecon, Cwm Duff, 3.vi.1970, 1 우 (A. E. Stubbs leg.) (JSO). England: Shropshire, Chelcott Coppice, 24.v.2003, 91 ơ, 27 ? (A. Godfrey leg.) (JSO; in ethanol); Yorkshire, Littlebeck Wood nr. Whitby, 7.vi.2002, 10َ; Grass Woods nr. Grassington, 25.vi.2002, 1 (both R. Crossley leg.) (both JSO). Spain: Tributary of Rio Ter nr. Mollo, (1000 m, $\left.2^{\circ} 24^{\prime} / 42^{\circ} 21^{\prime}\right)$, 17.v.1975, $10^{\star}$ (G. Theischinger leg.); Riera de Cattlas nr. Setcasas, 13.vii.1976, 40, 1 우 (W. Tobias leg.) (all JSO; in ethanol); Sierra de Gredos Mts, nr. Parador (1500 m), 27.v.1961, $1 \delta^{\text {t }}$ (B. Mannheims leg.) (ZFMK). France: Dept.
Haute-Garonne: Hospice de France, 25.vi.1950, 10 (F. Schmid leg.) (MHNN). Dept. Gard: $1.5 \mathrm{~km}$ E Pompignan (Mirabel) (210-240 m), 9.iv.1995, 10, 1\%; $1.5 \mathrm{~km}$ SW Claret, Lauret, 22.v.1993, $10,1+$ (all J.-P. Haenni leg.) (1 dried $q$ JSO; 20 , 1 \% MHNN, in ethanol). Germany: Bayern: Allgäu, Eschachtal (900 m), 23.vii.1971, 1 0 , 1 ㅇ (H. Mendl leg.) (ZFMK; in ethanol); Kemptener Wald, 15.ix.1970, 1 đo (H. Mendl leg.) (JSO; in ethanol); Allgäuer Alpen, Birksau, Ringang im Stillachtal (900 m), 1.vii.1975, 1 đ (J. Starý leg.) (JSO); Allgäuer Alpen, Diet-

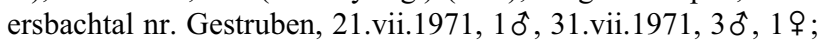
Traufbachtal (1200-1300 m), 7.ix.1970, 10, 18.viii.1974, 30, 6 ㅇ (all H. Mendl leg.) (all JSO; in ethanol); Traufbachtal (1400 m), 5.vii.1983, 60ิ, 2 (H. Mendl leg.) (ZFMK; in ethanol); Älpele (1500-1600 m), 31.vii.1971, 40, 3 ㅇ (H. Mendl leg.) (JSO; in ethanol). Czech Republic: Moravia: Vyšní Lhoty [6376], Morávka shores, 8.vi.1995, 3ठ, 3ㅇ, 13.vii.1995, 3 đ, 17.v.2001, 7ô, 8 ㅇ (J. Starý leg.) (JSO). Slovakia: Západné Tatry Mts, Oravice, Tichá dolina [valley] [6784] (800-850 m), 12.vi.2000, 1 ơ, 1 \%, 14.vi.2000, 1 \%; Západné Tatry, Roháčska dolina [valley] [6784] $(1050 \mathrm{~m})$, Zverovka [chalet] env., 27.vi.1998, 10; Belianske Tatry Mts, Tatranská Kotlina, Belá valley [6788] $(750 \mathrm{~m})$, 26.vii.1974, 1ठ, 27.vii.1974, 1ठ, 31.vii.1974, 1 ô, 22.vi.1975, 3 ô, 1 우 (1 0 J. Martinovský leg.),

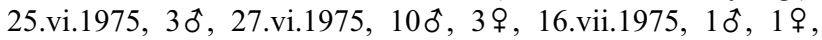
18.vii.1975, 1ठิ, 1, 19.vii.1975, 2ठิ, 1ㅇ, 22.vii.1975, 1우, 25.v.1976, 1ठ, 29.v.1976, 20ิ, 2ㅇ, 30.v.1976, 10, 2ㅇ, 18.vi.1977, 20ิ, 6우, 20.vi.1977, 1ठ, 23.vi.1977, 1ठ, 1.vii.1978, 1ठิ, 2ㅇ, 3.vii.1978, 1ठ, 4.vii.1979, 3ठิ, 5.vii.1979, 1ठึ; Lendak [6788], Belá shores, 29.v.1976, 1q; Hostovice 
[6898], Udava shores, 16.vi.1986, 1 ㅇ, 19.v.1987, 10; Snina, Cirocha shores [7099], 21.vi.1983, 19, 22.vi.1983, 10, 2.vi.1984, 1 ㅇ, 1.vi.1985, 1ठ, 8.vi.1985, 1ठ; Bukovské Hills, Ruské [6800], Cirocha shores, 3.vi.1985, 3 우 (all J. Starý leg.) (all JSO). Austria: Tirol, Obladis, 7.7.1889, 10 (J. Mik leg.) [listed as schistacea by Lackschewitz, 1940] (NHMW); Obertillach, undated, $2 \hat{o}$ (R. Frey leg.) (ZFMK). Oberösterreich: Mitterweissenbach, 10.vii.1977, 20, 19 (G. Theischinger leg.). Steiermark: Leoben $(830 \mathrm{~m}), 23 . v i .1976,10^{\dagger}$ (R. Wagner leg.). Kärnten: Leobengraben (1200 m), 26.vii.1981, 1 के (R. Wagner leg.). (All JSO; in ethanol). Italy: Liguria: Bromida di Pallave, 14.v.1980, 10 (P. Zwick leg.) (JSO; in ethanol). Lombardia: Staffora nr. Molino di Pietro above Varzi, 11.v.1980, 60, 1 ㅇ (P. Zwick leg.) (JSO; in ethanol). Trentino-Alto Adige: Val d'Ampola, 3.vi.1971, 100ิ, 4\% (H. Mendl leg.) (JSO; in ethanol). Fruili-Venezia Guilia: Cave del Predil [Raibl], 1889 , 1 ㅇ (Mann leg.) [listed as schistacea by Lackschewitz, 1940] (NHMW). Marche: Mti Sibillini, Madonna dell'Ambro, 24.v.1977, 1 ㅇ (P. Zwick leg.) (JSO; in ethanol). Campania: Mti della Laga, Padula, 23.v.1977, $1 \delta^{\star}$ (H. Mendl leg.) (JSO; in ethanol). Slovenia: Podnart nr. Kranj, 7.v.1977, 10 (I. Sivec leg.) [listed as subparva by Mendl, 1984a] (ZFMK; in ethanol). Bosnia and Hercegovina: Sarajevo, 16.vii.1929, $10^{\star}$ (H. Zerny leg.) [listed as schistacea by Lackschewitz, 1940] (NHMW). Albania: Skutari, 1917, 1 9 (Karny leg.) [listed as schistacea by Lackschewitz, 1940 and Mannheims, 1967] (NHMW). Bulgaria: Stara Kresna, 8.v.1989, 5 ô, 4 \%; Melnik, 10.v.1989, 5 ô (all J. Starý leg.) (all JSO).

Discussion. There is a certain variation in the body size and colouration. Specimens from Great Britain and South Europe are, on the average, smaller, somewhat more robust, and darker, rather dark greyish brown, with the wings strongly infuscated and with the bluish pruinosity limited to the pleuron. Members of Central European populations are larger, more slender, generally somewhat paler, with a very distinct bluish suffusion that passes from the pleuron onto the prescutum and other dorsal parts of the thorax.

The species concept of $R$. (R.) edwardsi has been one of the controversies of this revision, since specimens from various regions differ in various aspects (see above). Although the species had been described and illustrated adequately (cf. Tjeder, 1967: 225, Figs 1-10), it does not seem to have been well recognised, and it only was accepted as occurring in Great Britain. It has never been reported outside that country, except for records from the Czech Republic and Slovakia (Starý, 1987), later doubted (see Distribution). From the beginning of my studies on Rhabdomastix, the sympatric material of two forms was available to me from the former Czechoslovakia, differing considerably in the body colouration from both $R$. (R.) subparva, the most common regional species, and from each other. The one form was distinctive by a bluish pruinosity on the pleuron (these specimens may occur in various collections labelled by me as "caesia"), whereas the other form was entirely black. The sympatric occurrence of these forms supported the view that they represent valid species. The solution reached after a thorough comparison, repeated many times, is now believed to be a correct one: form No. 1 is $R$. (R.) edwardsi and form No. 2 is a new species described below as $R$. (R.) crassa sp. n.
The bluish pruinosity, rather dark and intensive, differentiates $R$. (R.) edwardsi from all species treated here, except perhaps $R$. $(R$.) hirticornis, which, however, is sufficiently distinctive by its very long male antennae. In the structure of the male terminalia, $R$. (R.) edwardsi appears to be most closely related to $R$. $(R$.) crassa $\mathrm{sp}$. n. and $R$. $(R$.) corax sp. n., both entirely black species. $R$. (R.) edwardsi differs from these species in having a generally straight outer gonostylus (gently and evenly arched in corax) and rather long, slender interbases (shorter and broader in crassa, more rounded at apex). Some other external and male genital features differentiating the three species are specified in the discussions of the two latter. The female terminalia of the three species are very similar to each other, having the spermathecae of approximately the same size. $R$. (R.) edwardsi has the cerci slightly longer and more slender than the other two.

Distribution. So far the species has been known from Great Britain only. Records from the Czech Republic and Slovakia (Starý, 1987), based on unpublished material, were later withdrawn (Starý, 1993, 1996). Records are presented here for Great Britain, Spain, France, Germany, Czech Republic, Slovakia, Austria, Italy, Slovenia, Bosnia and Hercegovina, Albania and Bulgaria.

\section{Rhabdomastix (Rhabdomastix) crassa sp. $\mathbf{n}$.}

(Figs 4, 7, 14, 30-31)

Gonomyia (Rhabdomastix) schistacea: Lackschewitz, 1940: 56 (alternatively as Gonomyia (Sacandaga), faun. record) [partim, see present revision].

Diagnosis. General colouration black throughout. Antenna short. Wing narrow, strongly infuscated. $\mathrm{A}_{2}$ ending far before origin of Rs. Legs dark brown, including coxae. Male terminalia with outer gonostylus generally straight, with distinct apical spine, and apical blade of interbase spoon-shaped. Female terminalia with three spherical, small spermathecae.

Description. Very small species, plump in general appearance, with all body appendages (antennae, palpi, wings, legs) slightly shorter, compared to other species. Body length 3-6 mm, wing length 3-5 mm.

Colour. General colouration black, dull (deep dark brown in faded dried specimens), without conspicuous markings on thorax. Antenna almost black throughout. Pleuron heavily suffused with dark greyish black pruinosity. Wing strongly tinged with blackish. Halter infuscated, especially on stem. Coxae deep dark greyish brown. Trochanters and bases of femora brown, the latter darkened distally, deep dark brown. Rest of legs dark brown. Abdomen almost black, somewhat shiny.

Male. Head. Antenna (Fig. 7) comparatively short, not reaching to base of wing. Flagellomeres short-oval. Longest verticils on flagellomeres subequal in length to their respective segments. Pubescence indistinct. Palpus short (Fig. 14).

Thorax. Wing (Fig. 4) rather narrow, about four times as long as broad, with stalk very short. $\mathrm{Sc}_{1}$ ending at about half length of Rs or slightly before it. $\mathrm{Sc}_{2}$ littledistinct at tip of $\mathrm{Sc}_{1} . \mathrm{R}_{3}$ more than its own length beyond tip of $R_{1}$. $R_{4}$ bare or with at most a few macrotrichia dor- 

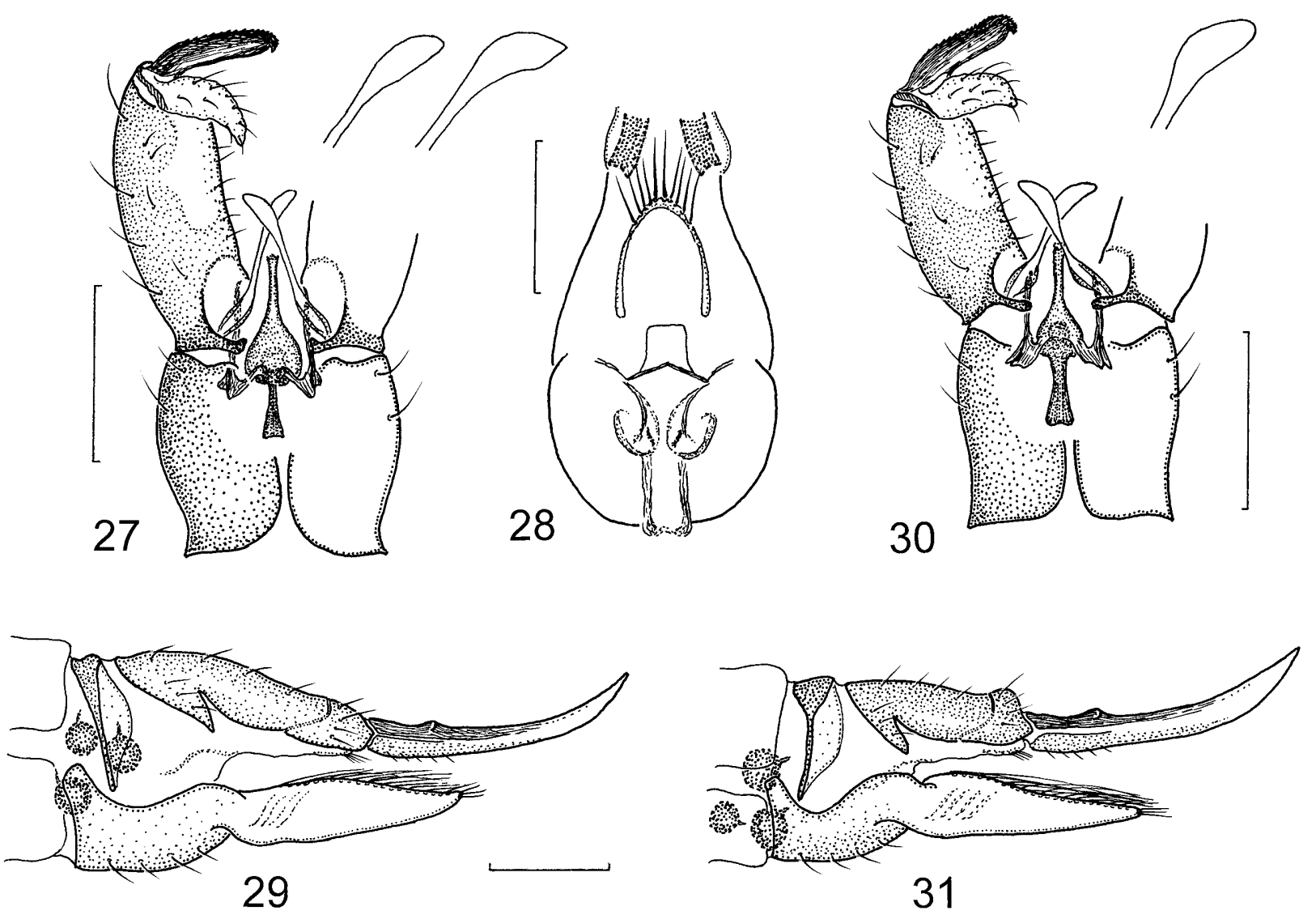

Figs 27-31. 27-29. Rhabdomastix (Rhabdomastix) edwardsi Tjeder, 1967 (Scotland: Braemar). 27 - male terminalia, general view, dorsal (details show variation in shape of apical blade of interbase); 28-29 - female terminalia, internal structures ventral (28) and general view, lateral (29). 30-31. R. (R.) crassa sp. n. (paratypes, Czech Republic: Hrubá Voda nr. Olomouc). 30 - male terminalia, general view, dorsal; 31 - female terminalia, general view, lateral. Scale bars $0.25 \mathrm{~mm}$.

sally. A $A_{2}$ slightly sinuous, ending far before origin of Rs. Halter comparatively short, not reaching to posterior margin of abdominal tergite 2. Legs rather thick and short, compared to other species.

Abdomen. Male terminalia (Fig. 30). Segment 9 longer than broad. Gonocoxite stout, broad. Outer gonostylus comparatively short, about half length of gonocoxite, bent only at base, straight distally, generally parallel-sided, with distinct apical spine. Inner gonostylus generally conical. Aedeagal complex as in Fig. 30. Interbase shorter than in $R$. (R.) edwardsi, reaching to about half length of gonocoxite (this likewise shorter than in edwardsi), not as slender as in the latter species, slightly bent distally, with apical blade spoon-shaped, distinctly larger, rounded at apex. Aedeagus slender, subequal in length to vesica, the latter broad, bulbous, with apodeme narrowly fan-shaped in dorsal aspect, about same length as vesica. Female terminalia (Fig. 31). Cercus comparatively slender and long, longer than tergite 10 , yet somewhat broader and shorter than that of $R$. (R.) edwardsi, gently upturned. Spermathecae three, small, spherical, subequal in size to $R$. (R.) edwardsi, with sclerotised parts of ducts very short. One spermatheca sometimes smaller than other two.

Material examined. Holotype đ̊ : Czech Republic, Moravia, Hrubá Voda nr. Olomouc [6370], 16.v.1975 (J. Starý leg.) (SMOC). The specimen is glued onto a triangular cardboard point, with only left hind leg and apex of abdomen missing. Terminalia dissected and placed in a sealed plastic tube with glycerine, pinned with the specimen. Paratypes $\left(2260^{\star}, 116 \%\right)$ : France: Eastern Pyrenées, Vernet-les-Bains, 11.-18.vi.1924, 2 (H. Zerny leg.) [listed as schistacea by Lackschewitz, 1940] (NHMW). Czech Republic: Bohemia: Malenice [6849] (distr. Strakonice), Volyňka shores, 12.v.2003, 12 đ, 2 우 (J. Starý leg.) (JSO). Moravia: Jívová nr. Olomouc [6270], 22.v.1975, 10ิ, 28.v.1975, 60ิ, 1ㅇ, 19.v.1976, 40ิ, 8ㅇ, 20.v.1992, 10ิ, 8.v.1999, 4ठิ, 1 우, 5.v.2000, 1 ऊे; Smilov nr. Olomouc [6370], 18.vi.1972, 1ठ, 19.v.1976, 14ðิ, 8ㅇ, 18.v.1978, 1ठ; Hrubá Voda nr. Olomouc [6370], 18.vi.1970, 15 0 , 3ㅇ, 19.vi.1970,

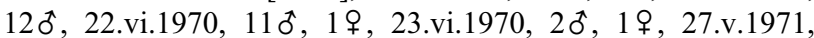

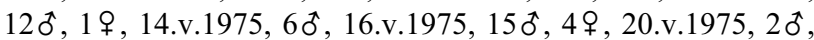

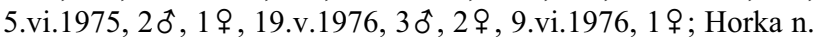
M. [6369], Morava shores, 29.v.1995, 9ð, 6 $9,31 . v .1996,4 \hat{\text {, }}$ 4ㅇ, 5.vi.1996, 3ㅇ, 26.v.1997, 30ิ, 3ㅇ, 29.v.1998, 10ิ, 39 , 3.v.1999, 1ठ , 11.vii.1999, 2đ, 2q; Nové Oldřůvky [6271], Odra valley, 2.vi.1993, $5 \hat{\delta}, 3$ के, 22.vi.1993, 10ิ, 11.vi.1997, 10, 1 ; ; Suchdol n. O. [6373], Odra shores, 4.vi.1980, 18 के, $23+(20,12$ \% ZFMK; in ethanol), 12.vi.1980, 10, 7.v.1981,

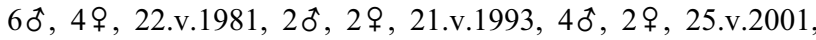
20ิ, 19; Lazníky nr. Přerov [6470], 22.v.1979, 20ิ, 19 , 16.v.1985, 1, 18.v.1985, 1 \% , 7.v.1986, 20; Kašava [6772], Dřevnice valley, 14.v.1985, 50 , 1 \%; Vlčovice nr. Kopřivnice [6475], Tichávka shores, 2.v.2002, 10, 1\%; Radějov [7170], Radějovka valley, 14.v.1983, 2 đ (all J. Starý leg.) (except as stated all JSO, SMOC). Slovakia: Očová nr. Zvolen [7381], Hučava valley, 17.vi.2003, 2ð, 6, 19.vi.2003, 1ð, 1\%; Krup- 
inská Upland, Litava valley nr. Cerovo [7780], 13.v.1993, 1 đ 1, 2.vi.1997, 50ิ, 4; Hranovnica [7087], Hornád shores, 1.vii.1979, 1 đે, 1 ㅇ; Slavec [7488], Slaná shores, 20.v.1980, 2 đ, 1 , 23.v.1980, 9ठ̊; Hostovice [6898], Udava shores, 19.v.1987, 1o; Snina, Cirocha shores [7099], 2.vi.1984, 1\%; Stakčín, Chotinka valley [6999], 3.vi.1984, 20, 1\%, 2.vi.1985, 1 , 6.vi.1985, 10ิ; Bukovské Hills, Ruské [6800], Cirocha shores, 7.vi.1985, 10, 20.v.1987, 3 ô, 1 q (all J. Starý leg.) (all JSO).

Etymology. The name of the new species, crassa (= thick, stout), refers to its somewhat plump general appearance, with all body appendages slightly shorter than in the other species. An adjective in nominative singular.

Discussion. $R$. (R.) crassa sp. n. is, on the average, the smallest of the species treated here, long known from numerous localities in the Czech Republic and Slovakia. It is distinctive by its generally plump appearance, short verticils on antennae and the black body colouration. Within European species, the latter character is only shared by $R$. (R.) corax sp. n., which differs from $R$. $(R$.) crassa sp. n. in having a light grey pruinosity on the pleuron and more macrotrichia on $\mathrm{R}_{4}$. In the structure of the male terminalia, $R$. (R.) crassa sp. n. is very similar to $R$. (R.) edwardsi and $R$. (R.) corax sp. n., differing from either or both in having the outer gonostylus generally straight (gently and evenly arched in corax), the inner gonostylus moderately broad (more slender in corax), the interbase short and comparatively broad (longer and more slender in both edwardsi and corax), and the apodeme of the vesica narrowly fan-shaped (more slender in corax, rod-like or spine-like). The female terminalia of the three species are not well distinguished having the spermathecae of approximately the same size, but the features listed above clearly validate $R$. (R.) crassa sp. n. as a separate species.

Distribution. France, Czech Republic, Slovakia.

Note. It should be stated that the Japanese $R$. atrata Alexander, 1925, described from Honshu, Japan (Alexander, 1925a: 436) [holotype $\widehat{\delta}$ : Emi-mura, Chiba-Ken, 6.vii.1923 (T. Yokoyama leg.) (USNM)], also entirely black, is specifically distinct from both $R$. (R.) crassa sp. n. and $R$. (R.) corax sp. n., and it is not even conspecific with what was recorded and illustrated as $R$. atrata by Savchenko \& Krivolutskaya (1976: 87, Figs 36a,b) from the South Kuriles [Kunashir Is, Tretiakovo env., 6.-7.viii.1971, 1 oิ, 1 ㅇ (E.N. Savchenko leg.) (JSO)]. Interestingly, the latter two specimens are identical with two males on slides (incl. hypopygia) from Honshu, Japan [Kurokawa, 17.vi.1955 (K. Baba leg.) (USNM)], identified as $R$. atrata by Alexander.

\section{Rhabdomastix (Rhabdomastix) corax sp. n.}

(Figs 32, 36)

Diagnosis. General colouration black, with light grey pruinosity on pleuron. Antenna short. Wing narrow, strongly infuscated. $\mathrm{A}_{2}$ ending before origin of Rs. Legs dark brown, including coxae. Male terminalia with outer gonostylus gently arched, with distinct apical spine, and apical blade of interbase lanceolate. Female terminalia with three spherical, small spermathecae.

Description. Small species. Body length 3-5.5 mm, wing length $3.5-5 \mathrm{~mm}$.
Colour. General colouration black, dull (deep dark brown in faded dried specimens), without conspicuous markings on thorax. Antenna almost black throughout. Pleuron slightly suffused with light grey pruinosity. Wing strongly infuscated, blackish. Halter infuscated throughout. Coxae deep dark greyish brown. Trochanters and bases of femora brown, the latter still darkened distally, deep dark brown. Rest of legs dark brown. Abdomen almost black.

Head. Antenna comparatively short, not reaching to base of wing. Flagellomeres short-oval. Longest verticils on flagellomeres slightly exceeding length of their respective segments. Pubescence indistinct. Palpus short.

Thorax. Wing rather narrow, about four times as long as broad, with stalk comparatively long, longer than that of $R$. (R.) crassa sp. n. $\mathrm{Sc}_{1}$ ending at about half length of Rs or slightly before it. $\mathrm{Sc}_{2}$ not apparent. $\mathrm{R}_{3}$ more than its own length beyond tip of $\mathrm{R}_{1}$. $\mathrm{R}_{4}$ with about 10 macrotrichia, mostly dorsally. $\mathrm{A}_{2}$ slightly sinuous, ending before origin of Rs. Halter moderate in length, reaching to posterior margin of abdominal tergite 2 .

Abdomen. Male terminalia (Fig. 32). Segment 9 longer than broad. Gonocoxite moderate in length and breadth. Outer gonostylus comparatively short, about half length of gonocoxite, considerably bent at base, otherwise gently and evenly arched, generally parallel-sided, sometimes slightly tapered distally, with barely distinct apical spine. Inner gonostylus generally conical, more slender than in other related species. Aedeagal complex as in Fig. 32. Interbase moderate in length, reaching slightly beyond half length of gonocoxite, slender, bent near two-thirds of its length to form lanceolate apical blade, similar to that of $R$. (R.) subparva. Aedeagus short, subequal in length to vesica, the latter broad, bulbous, with long apodeme, subequal in length to vesica, rod-like or spine-like in dorsal aspect. Female terminalia (Fig. 36). Cercus moderate in length and breadth, subequal in length to tergite 10 , gently upturned. Spermathecae three, small, spherical, subequal in size to both $R$. (R.) edwardsi and $R$. (R.) crassa sp. n., with sclerotised parts of ducts practically not apparent. One spermatheca sometimes smaller than other two.

Material examined. Holotype $\delta$ : Bulgaria, Pirin Mts, Bansko env. (1000 m), 20.vii.1987 (J. Starý leg.) (SMOC). The specimen is glued onto a triangular cardboard point, without right fore and hind legs and apex of abdomen. Terminalia dissected and placed in a sealed plastic tube with glycerine, pinned with the specimen. Paratypes (5o, 9 $q$ ): Bulgaria: Pirin Mts, Lilianovo nr. Sandanski, 15.vi.1990, 3ㅇ, 17.vi.1990, 10, 3 \% Pirin Mts, Popina laka (1200 m), 19.vi.1990, 20; Pirin Mts, Bansko env. (1000 m), 20.vii.1987, 10, 3 우 (all J. Starý leg.) (all JSO). Greece: Evvoia Is. [Euböa, Euboeia], $1 \mathrm{~km} \mathrm{NW}$ Dafni (1700 m), 1.v.1975, 10 (H. Malicky leg.) (JSO; in ethanol).

Etymology. The new species is named corax (= the rook) for its notably black body. A noun in nominative singular standing in apposition to generic name.

Discussion. This new species is distinctive by its black body colouration, being thus similar to $R$. (R.) crassa $\mathrm{sp}$. $\mathrm{n}$., from which it differs by some external and genital 
characters, such as the overall slender appearance, the setosity of $\mathrm{R}_{4}$, the shape of both gonostyli (the outer gonostylus of corax somewhat suggesting that of subparva) and the structure of the aedeagal complex. For details, see the discussion of $R$. (R.) crassa sp. n.

Distribution. Bulgaria, Greece.

\section{Rhabdomastix (Rhabdomastix) eugeni sp. n.}

(Figs 8, 15, 33, 37, 51)

Diagnosis. General colouration greyish brown on thorax, more brownish on abdomen. Antenna short. Wing narrow, slightly infuscated. $\mathrm{A}_{2}$ ending before origin of Rs. Legs brown with yellow coxae. Male terminalia with outer gonostylus gently arched, rounded at apex, with apical spine not apparent, and apodeme of vesica short. Female terminalia with two reniform, medium-sized spermathecae.

Description. Small species. Body length $3.5-6.5 \mathrm{~mm}$, wing length 4-5.5 mm.

Colour. General colouration dark greyish brown to light grey, dull, without conspicuous markings on thorax, more brownish in middle of prescutum and sometimes still more so on abdomen. Antenna brown throughout. Pleuron heavily suffused with grey, sometimes greyish brown pruinosity. Wing slightly infuscated. Halter dirty white to pale yellow. Coxae, trochanters and bases of femora mostly yellow to yellowish brown, otherwise legs somewhat darker, brown. Abdomen greyish brown, proximal segments sometimes paler, brown, more conspicuously so ventrally. Sometimes abdomen entirely brown.

Head. Antenna (Fig. 8) comparatively short, not reaching to base of wing. Flagellomeres short-oval to oval. Longest verticils on flagellomeres slightly exceeding length of their respective segments. Pubescence indistinct. Palpus short.

Thorax. Wing rather narrow, about four to five times as long as broad, with short stalk (Fig. 15). $\mathrm{Sc}_{1}$ ending at about half length of Rs. $\mathrm{Sc}_{2}$ not apparent. $\mathrm{R}_{3}$ more than its own length beyond tip of $\mathrm{R}_{1}$. Macrotrichia on $\mathrm{R}_{4}$ somewhat varying in number, about 10 , mostly placed dorsally. $A_{2}$ sinuous, ending before origin of Rs. Halter comparatively short, not reaching to posterior margin of abdominal tergite 2 (Fig. 15).

Abdomen. Male terminalia (Fig. 33). Segment 9 longer than broad. Gonocoxite moderate in length and breadth. Outer gonostylus, on average, slightly longer than that of related species (except that of filata), more than half length of gonocoxite, gently and evenly arched or nearly straight distally, generally parallel-sided, rounded at apex, with apical spine barely distinct or lacking. Inner gonostylus rather broad, generally conical. Aedeagal complex as in Fig. 33. Interbase comparatively short and slender, reaching to about half length of gonocoxite, bent shortly before apex to form short and narrow, roughly lanceolate apical blade. Aedeagus slender, subequal in length to vesica, the latter broad, bulbous, with apodeme comparatively short, fan-shaped or rounded in dorsal aspect, shorter than vesica. Female terminalia (Figs 37, 51).
Cercus slender, rather long, longer than tergite 10, gently upturned. Spermathecae two, medium-sized, short-oval to reniform, with sclerotised parts of ducts short and curved.

Material examined. Holotype o : Slovakia, Snina, Cirocha shores [7099], 1.vi.1985 (J. Starý leg.) (SMOC). The specimen is glued onto a triangular cardboard point, with only right mid leg and apex of abdomen missing. Terminalia dissected and placed in a sealed plastic tube with glycerine, pinned with the specimen. Paratypes (136 $\hat{\sigma}, 104 \%)$ : France: Dept. Aude: Etang de Gruissan (0 m), 7.-10.vi.1980, 1 으 (W. Schacht leg.). Dept. Basses-Alpes: Montagne de Lure, Cruis $(500 \mathrm{~m})$, 29.vi.1978, 10 ; Lauzon nr. Cruis (500 m), 14.vi.1980, 4 우 (all W. Schacht leg.). (All JSO; in ethanol). Switzerland: Canton Valais: Vuisse, 3.-29.viii.1980, 20 (W. Geiger leg.). Canton Ticino: Gordevio, middle vi.- early ix.1980, 14우, early vii.1979, 1 9 (L. Rezbanyai leg.; Malaise light trap); Aurigeno (341 m), 7.viii.-28.ix.1980, 1 (W. Geiger leg.). (All MHNN; in ethanol). Germany: Iller N Fellheim, 1.viii.1985, 50; Allgäuer Alpen, Birksau, Ringang im Stillachtal $(900 \mathrm{~m})$, 11.-15.viii.1974, 1 + , 18.-22.viii.1974, 4 우 (all H. Mendl leg.; light trap) (all in ethanol, 19 dried from ethanol), 1.vii.1995, 30,1 (J. Starý leg.) (all JSO). Czech Republic: Moravia: Vyšní Lhoty [6376], Morávka shores, 9.v.2000, 4 ㅇ (at light); Lobodice nr. Tovačov [6669], 21.v.1981, 20, 1 9 , 27.v.1981, 10, 30.v.2001, 6ㅇ (at light), 20.v.2002, 19 (at light), 19.vi.2002, 2 ㅇ (at light), 5.vi.2003, $15 \%$ (12 $q$ at light), 8.vi.2003, 10, $3 \uparrow$ (all J. Starý leg.) (all JSO). Slovakia: Piešt'any [Pöstyén] [7472], 10 (K. Kertész leg.) (MMBC); Hostovice [6898], Udava shores, 16.vi.1986, 40ิ (10 ZFMK; in ethanol), 19.v.1987, 1\%; Snina, Cirocha shores [7099],

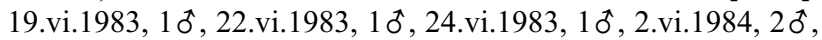
4.vi.1984, 19, 1.vi.1985, 22 ठิ, 69, 3.vi.1985, 10ิ, 8.vi.1985, 2 ô, 3 우 (1 đิ ZFMK; in ethanol); Bukovské Hills, Ruské [6800],

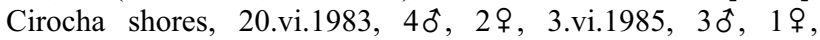
7.vi.1985, 3 ô, 1ㅇ, 6.viii.1985, 30ิ, 19.vi.1986, 20ิ; Bukovské Hills, Ruský Potok [6900], 5.viii.1985, 20َ; Bukovské Hills, Nová Sedlica [6901], Zbojský brook, 8.vi.1988, 3ठ, 21.vi.1991, 50ิ, 1우 7.vii.1993, 80ิ, Nová Sedlica env., 13.vi.1991, 1\%; Bukovské Hills, Zboj [6900], Zbojský brook, 19.vi.1991, 40ิ, 8.vii.1993, 7 ô, 4ㅇ, 15.vi.1996, 3 ô, 1 우 ; Bukovské Hills, Krivé [7000], Zbojský brook, 17.vi.1991, 1 đo (all J. Starý leg.) (except as stated all JSO, SMOC). Italy: Piemonte: Roreto Chisone, Villaretto, Torrente Chisone (920 m), 8.ix.2000, $1 \hat{0}$ (G.B. Delmastro leg.) (JSO; dried from ethanol). Emilia-Romagna: $40 \mathrm{~km}$ S Bologna, Torre Setta nr. Rioveggio, 22.v.1990, 110, 2 아. Mendl leg.) (ZFMK; in ethanol). Campania: Mti del Cilento, Calore nr. Laurino, 4.v.1977, 30 (H. Mendl leg) (JSO; in ethanol). Calabria: Maria del Cedro, Lao valley, 28.v.1996, $2 \hat{0}$, 30.v.1996, 4ठิ, 1 ㅇ, 5.vi.1996, 1 đ (J. Martinovský leg.) (JSO). Romania: Orsova, vi., 10 (Th. Becker leg.) [paralectotype of beckeri; for details, see under beckeri] (ZMHB). Bulgaria: Rodopi Mts, Bachkovo, 20.vi.1982, 1 \% (W. Krzemiński leg.); Kresna (railway station), 31.v.1976, 1 우 (at light), 1.vi.1976, 3 우 (P. Lauterer leg.; in ethanol); Sandanski, 14.vi.1984, 20 (W. Krzemiński leg.), Struma valley, 30.v.1989, 20 (J. Starý leg.) (all JSO). Greece: Platamon, Prov. Katerini, Castle-Camping, 7.-14.vi.1968, 2 ㅇ (B. Mannheims leg.; at light) (ZFMK); Diakopion, 25 km WNW Amfissa, 13.-14.v.1978, 30 (G. Theischinger leg.); Thasos Is., Ipsarion (1000 m), 6.vi.1973, 2 ㅇ (H. \& U. Aspöck, H. Rausch \& P. Ressl leg.); Evvoia Is. [Euböa, Euboeia], S Prokopion (250 m), 24.v.1974, 3 (H. Malicky leg.) (all JSO; in ethanol); Lilaia, 29.vi.1976, 3 \% Peloponnes, W Karterion (730 m), 19.v.1974, 10, 3 ㅇ (all H. Malicky leg.) (all ZFMK; in ethanol). Ukraine: Zakarpatskaya oblast: Bogdan env., 4.vii.1969, 1ठ, 5.vii.1969, 10; Svidovetskiy [mountain 

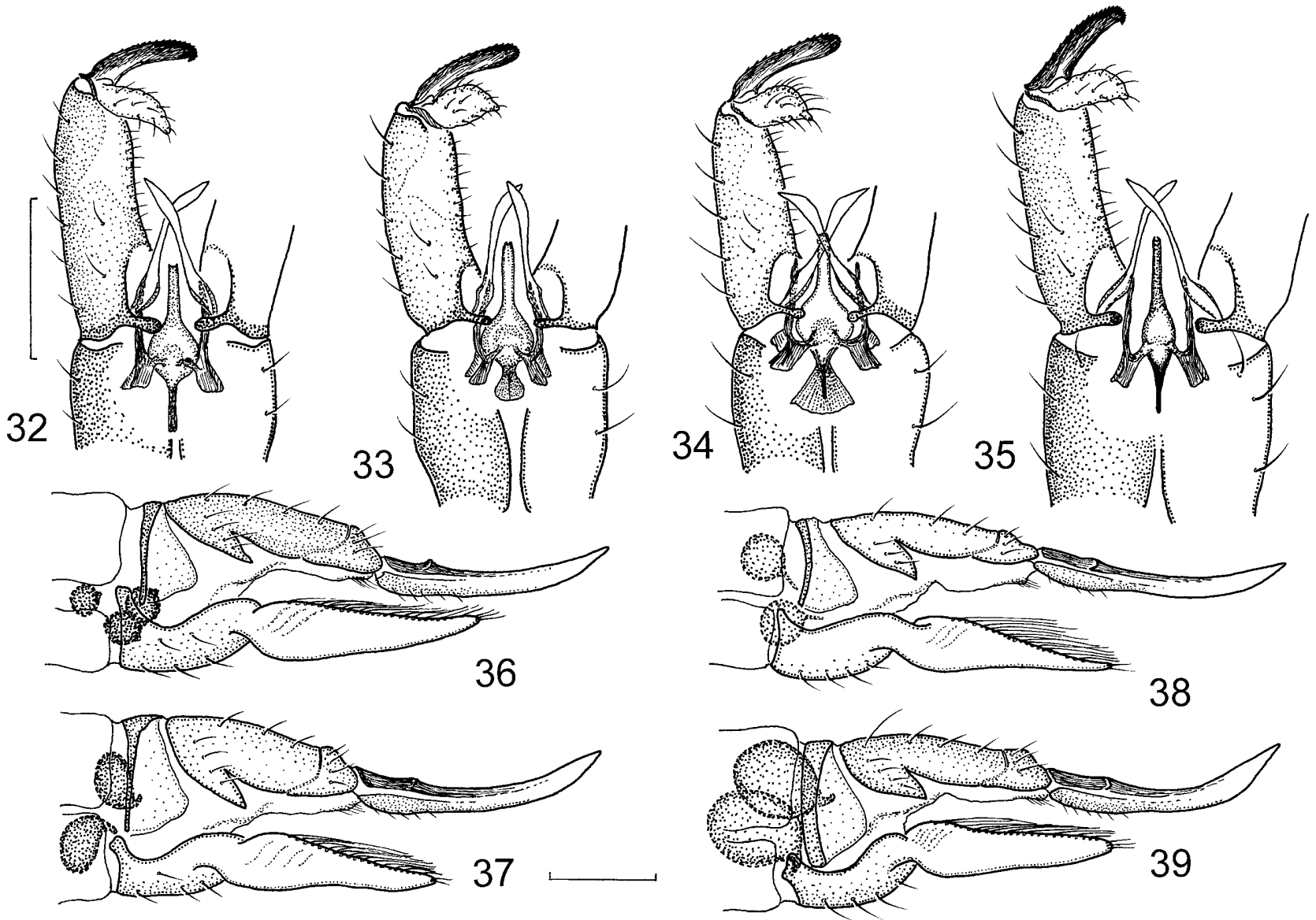

Figs 32-39. 32-35. Male terminalia, general view, dorsal. 32 - Rhabdomastix (Rhabdomastix) corax sp. n. (holotype); $33-R$. (R.) eugeni sp. n. (holotype); $34-R$. (R.) filata sp. n. (holotype); $35-R$. (R.) subparva Starý, 1971 (Czech Republic: Hrubá Voda nr. Olomouc). 36-39. Female terminalia, general view, lateral. $36-R$. (R.) corax sp. n. (paratype, Bulgaria: Bansko); $37-R$. $(R$.) eugeni sp. n. (paratype, Slovakia: Snina); $38-R$. (R.) filata sp. n. (paratype, Lebanon: Becharré); 39 - R. (R.) subparva Starý, 1971 (Czech Republic: Hrubá Voda nr. Olomouc). Scale bars $0.25 \mathrm{~mm}$.

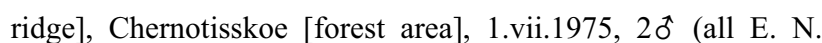
Savchenko leg.). Ivano-Frankovskaya oblast: Pasechnoe env., 27.vi.1969, 1 ㅇ, 28.vi.1969, 1 đo (E.N. Savchenko leg.). Chernovitskaya oblast: Zhadova Nova env., 4.vi.1974, 20 (E.N. Savchenko leg). (All JSO). Armenia: Rayon Azizbekov, Khanderud env., 30.viii.1970, 1 9 (E.N. Savchenko leg.) (JSO).

Etymology. The new species is named in honour of the late Dr. Yevgeniy (= Eugen) Nikolaevich Savchenko (Kiev, Ukraine), a distinguished specialist on the Limoniidae (s. lat.) and Tipulidae, who first collected this species and who was able, under conditions inconceivable to his colleagues from the then so-called free world, to do so much on the craneflies. A noun in genitive singular.

Discussion. Whereas members of Central European populations are dark greyish brown, most resembling $R$. (R.) subparva, the specimens examined from the Balkans are somewhat paler, bicoloured, having a light grey thorax and brown abdomen. Surprisingly, a few specimens examined from Calabria (southern Italy) are rather dark, much as the Central European individuals.

$R$. (R.) eugeni sp. n., if from Central Europe, most resembles $R$. (R.) subparva by its dark greyish brown body colouration and yellow coxae. It differs from the latter, as do other related species, in that it is not as slender in general appearance as R.(R.) subparva, having the wing stalk and halter shorter (cf. Figs 15 and 16). In $R$. (R.) eugeni sp. n., $\mathrm{R}_{4}$ bears about 10 macrotrichia (more numerous, about 20, in subparva, fewer or none in edwardsi, crassa and filata). Specimens of $R$. (R.) eugeni sp. n. from the Balkans are paler, bicoloured, thus somewhat resembling $R$. (R.) filata sp. n. and the Balkan specimens of $R$. (R.) hirticornis, both quite different in the structure of the antennae. $R$. $(R$.) eugeni sp. n. is probably most closely related to $R$. (R.) filata $\mathrm{sp}$. $\mathrm{n}$. in having the outer gonostylus rounded at apex, without an apparent apical spine, it differs, however, from the latter by a small apodeme of vesica in males (large, broadly fan-shaped in filata) and reniform spermathecae in females (spherical in filata).

Distribution. France, Switzerland, Germany, Czech Republic, Slovakia, Italy, Romania, Bulgaria, Greece, Ukraine, Armenia.

\section{Rhabdomastix (Rhabdomastix) filata sp. n.}

(Figs 9, 34, 38, 52)

Gonomyia (Rhabdomastix) schistacea: Lackschewitz, 1940: 56 (alternatively as Gonomyia (Sacandaga), faun. record) [partim, see present revision]. 
Rhabdomastix (Sacandaga) subparva: Mendl: 1986: 278 (faun. record) [see present revision]

Diagnosis. General colouration light grey on thorax, pale brown on abdomen. Antenna short, with pedicel large and flagellum very slender. Wing narrow, nearly hyaline. $\mathrm{A}_{2}$ ending opposite to origin of Rs or slightly before it. Legs yellowish brown, with yellow coxae. Male terminalia with outer gonostylus straight, rounded at apex, apical spine not apparent; apodeme of vesica large, broadly fan-shaped. Female terminalia with two spherical, medium-sized spermathecae.

Description. Small species. Body length 4-5.5 mm, wing length $4.5-5.5 \mathrm{~mm}$.

Colour. General colouration grey to light grey, dull on thorax, without conspicuous markings. Antenna pale brown to brown throughout. Pleuron variably suffused with whitish grey pruinosity. Wing hyaline or slightly tinged with yellowish. Halter whitish yellow. Coxae, trochanters and bases of femora yellow, rest of legs somewhat darker. Abdomen light brown, subshiny.

Head. Antenna (Fig. 9) short, not reaching to base of wing, with pedicel large, compared to other species, and flagellum very thin, filiform. Flagellomeres mostly elongate-oval, slender, except more rounded first flagellomere. Longest verticils on flagellomeres exceeding length of their respective segments. Pubescence indistinct. Palpus short.

Thorax. Wing rather narrow, about four times as long as broad, with short stalk. $\mathrm{Sc}_{1}$ ending at about half length of Rs. $\mathrm{Sc}_{2}$ sometimes slightly apparent at tip of $\mathrm{Sc}_{1} \cdot \mathrm{R}_{3}$ more than its own length beyond tip of $R_{1}$. $R_{4}$ with at most a few macrotrichia dorsally. $A_{2}$ sinuous, ending opposite to origin of Rs or shortly before it. Halter short, not reaching to posterior margin of abdominal tergite 2 .

Abdomen. Male terminalia (Fig. 34). Segment 9 longer than broad. Gonocoxite moderate in length and breadth. Outer gonostylus slightly more than half length of gonocoxite, bent at base, otherwise straight, parallel-sided, rounded at apex, with apical spine sometimes not apparent. Inner gonostylus generally conical, somewhat swollen. Aedeagal complex as in Fig. 34. Interbase reaching beyond half length of gonocoxite, bent shortly before apex to form narrow, roughly lanceolate blade. Aedeagus short, rather broad, subequal in length to vesica; the latter broad, bulbous. Apodeme of vesica large, broadly fanshaped in dorsal aspect, subequal in length to vesica. Female terminalia (Figs 38, 52). Cercus moderately broad, slightly exceeding length of tergite 10 , gently upturned. Spermathecae two, nearly spherical, mediumsized, with sclerotised parts of ducts comparatively thin, extending about one-third of spermathecal diameter.

Material examined. Holotype đa : Lebanon, Becharré (1400 m), 3.-10.vi.1931 (H. Zerny leg.) (NHMW), labelled: "NordLibanon Becharré, $1400 \mathrm{~m}$ 3.-10.V.31. Zerny" (printed), "Rhabd. schistacea Schumm. det. Lacksch." (printed) and accordingly labelled as holotype. The specimen is micro-pinned on a small piece of white matter, without right wing and apex of abdomen and with only right mid leg attached. Terminalia dissected and placed in a sealed plastic tube with glycerine, pinned with the specimen. Paratypes $(9 \widehat{\jmath}, 15 \%)$ : Bulgaria: Strandja
Mts, Katundere $(200 \mathrm{~m})$, 15.-16.vi.1980, 4 , below Mramor $(700 \mathrm{~m}), 20 . v i .1980,29$ (H. Malicky leg.) [listed as subparva by Mendl, 1986] (ZFMK; in ethanol). Greece: Lésvos Is. [Lesbos], $1 \mathrm{~km}$ E Chidira (210 m), 28.v.1975, 1 \% ; Ródos Is. [Rhodos], Kallithie $(110 \mathrm{~m}), 10 . v .1975,2$ \% Ródos Is., $3 \mathrm{~km} \mathrm{E}$ Archipolis (100 m), 9.v.1975, 1 ㅇ (all H. Malicky leg.) (all JSO; in ethanol). Russia (Europe): Krasnodarskiy kray, Lazarevskoe env., 23.v.1963, 1 o , 1 ㅇ, 24.v.1963, 1 우 (E.N. Savchenko leg.) (JSO). Turkey: Ardesen, 21.v.1970, 20 (P. Zwick leg.) (JSO; in ethanol). Georgia: Caucasus Mts, Yuzhnaya [South] Osetia, Kvemo-Zakhari env., 16.vii.1973, 10 (V.N. Logvinenko leg.); Adjaro-Imeretinskiy khrebet [mountain ridge], N slopes, $25 \mathrm{~km}$ from Bakhmaro to Makhardze, 24.viii.1970, $10^{\Uparrow}$ (S.I. Parkhomenko leg.) (all JSO). Armenia: Rayon Azizbekov, Khanderud env., 3.viii.1970, 10; Nagorniy Karabakh, Lachino env., 18.vi.1967, 1 \% (both E.N. Savchenko leg). (both JSO). Lebanon: Becharré (1400 m), 8.-10.vi.1931, 30, 2 ㅇ (H. Zerny leg.) [listed as schistacea by Lackschewitz, 1940] (20, 1 ㅇ

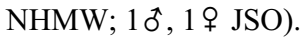

Etymology. The name of the new species, filata (= threadlike), refers to its very thin, filiform antennal flagellum. An adjective in nominative singular.

Discussion. $R$. (R.) filata $\mathrm{sp}$. $\mathrm{n}$. is distinctive by the structure of the antennae, having the pedicel large, compared to other species treated here, and the flagellum thin, filiform (Fig. 9). Body colouration is generally pale, bicoloured, with the light grey thorax and pale brown abdomen, similar to populations of $R$. (R.) hirticornis and $R$. (R.) eugeni sp. n. from the Balkans. $R$. (R.) filata $\mathrm{sp} . \mathrm{n}$. is close to $R$. (R.) eugeni sp. n., sharing with it the overall shape of the outer gonostylus, with rounded apex, without a distinct apical spine. It differs, however, from the latter by other details in the structure of the male and female terminalia, particularly the large, broadly fan-shaped apodeme of vesica in males and the spherical spermathecae in females.

Distribution. Bulgaria, Greece, Southeast European Russia, Turkey, Georgia, Armenia, Lebanon.

\section{Rhabdomastix (Rhabdomastix) subparva Starý, 1971}

(Figs 16, 35, 39, 53; Starý, 2003: 592, Fig. 6)

Gonomyia schistacea: Czižek, 1931: 79, 81 (diagnosis, faun. record, key), Figs 44a (male terminalia), b (wing) [see Starý, 1971: 154].

Rhabdomastix schistacea: Bangerter, 1939: 485 (faun. record); Bangerter, 1946: 192, 194 (faun. record) [both see Mendl, 1979a: 355].

Gonomyia (Rhabdomastix) schistacea: Lackschewitz, 1940: 56 [alternatively as Gonomyia (Sacandaga), faun. record] [partim, see present revision].

Rhabdomastix (Sacandaga) subparva Starý, 1971: 154 (description, conspecific with schistacea sensu Czižek nec Schummel), Figs 5-7 (male terminalia), 8-10 (female terminalia), 11 (male antenna), 12 (wing).

Rhabdomastix subparva: Starý \& Rozkošný, 1970: 116 (note) [nomen nudum]; Starý \& Geiger, 1998: 73 (list).

Rhabdomastix (Sacandaga) subparva: Mendl, 1973a: 257 (faun. record); Mendl, 1973b: 3 (diagnosis, faun. record); Mendl, 1974: 206 (faun. record); Mendl, 1975: 197 (faun. record); Savchenko, 1976: 564 (faun. record); Mendl, 1977: 116 (faun. record); Mendl, 1978: 373 (list); Mendl, 1979a: 355 (faun. record); Caspers, 1980: 57 (faun. record); Starý, 1980: 45 (faun. record); Caspers \& Noll, 1981: 207 (faun. record); 
Savchenko, 1982: 276, 281 (redescription, conspecific with schistacea sensu Czižek nec Schummel, faun. record, key), Figs 130/5 (wing), 131/2 (female terminalia), 135/3a,b (male terminalia); Krzemiński, 1984a: 30 (note); Mendl, 1984a: 7 (faun. record) [edwardsi, partim, see present revision]; Starý, 1984: 33 (faun. record); Noll, 1985: 123 (faun. record, note); Erhan-Dinca \& Ceianu, 1986: 89 (faun. record in list); Mendl, 1986: 278 (faun. record) [filata, see present revision]; Starý, 1987: 20 (list); Franz, 1989: 253 (faun. record); Krzemiński \& Starý, 1989: 263 (faun. record); Mendl \& Reusch, 1989: 434, 445 (list); Savchenko, 1989: 267 (conspecific with schistacea sensu Czižek nec Schummel, faun. record), Figs 132/4 (wing), 133/3 (male terminalia); Blanke \& Reusch, 1990: 706 (faun. record); Krzemiński, 1991: 80 (list); Savchenko et al., 1992: 316 (Palaearctic catalogue); Oosterbroek \& Starý, 1995: 7 (list); Starý, 1995: 30 (faun. record); Starý \& Oosterbroek, 1996: 72 (faun. record); Starý, 1997: 13 (list); Reusch, 1999: 58 (list); Reusch \& Oosterbroek, 2000: 160 (list); Reusch \& Zimmermann, 2000: 45 (faun. record).

Rhabdomastix (Sacandaga) subparva Starý, 1970: 44 (list) [nomen nudum].

Diagnosis. General colouration dark greyish brown. Antenna moderate in length. Wing narrow, slightly infuscated. $\mathrm{A}_{2}$ ending slightly before origin of Rs. Legs brown with yellow coxae. Male terminalia with outer gonostylus evenly arched, tapered distally, with distinct apical spine; apodeme of vesica long, rod-like. Female terminalia with two short-oval, very large spermathecae.

Redescription. Small species, very slender in general appearance, with all body appendages slightly longer, compared to other species centred around $R$. (R.) edwardsi (cf. Figs 15 and 16). Body length 3.5-6 mm, wing length 4-6.5 mm.

Colour. General colouration dark greyish brown, dull, without conspicuous markings on thorax. Antenna brown throughout. Pleuron heavily suffused with grey pruinosity. Wing slightly infuscated. Halter dirty white to pale yellow. Coxae, trochanters and bases of femora mostly yellow to yellowish brown, otherwise legs somewhat darker, brown. Abdomen greyish brown.

Head. Antenna of moderate length, reaching to base of wing. Flagellomeres oval. Longest verticils on flagellomeres exceeding length of their respective segments. Pubescence indistinct. Palpus short.

Thorax. Wing rather narrow, about four times as long as broad, with comparatively long stalk (Fig. 16). $\mathrm{Sc}_{1}$ ending at about half length of Rs. $\mathrm{Sc}_{2}$ slightly apparent at tip of $\mathrm{Sc}_{1}, \mathrm{R}_{3}$ more than its own length beyond tip of $\mathrm{R}_{1}$. $\mathrm{R}_{4}$ with numerous macrotrichia, about 20 , both dorsally and ventrally. $A_{2}$ sinuous, ending shortly before origin of Rs. Halter comparatively long (compared to other species), reaching to about posterior margin of abdominal tergite 2 (Fig. 16).

Abdomen. Male terminalia (Fig. 35). Segment 9 longer than broad. Gonocoxite moderate in length and breadth. Outer gonostylus comparatively short, about half length of gonocoxite, gently and evenly arched, tapered distally, with distinct apical spine. Inner gonostylus generally conical. Aedeagal complex as in Fig. 35. Interbase moderate in length, reaching to about half length of gonocoxite, generally slender, bent at two-thirds of its length to form long and slender, lanceolate apical blade. Aedeagus slender, longer than vesica; the latter narrow, with long apodeme, rod-like or spine-like in dorsal aspect, subequal in length to vesica. Female terminalia (Figs 39, 53). Cercus rather broad and short, subequal in length to tergite 10 , abruptly tapered and upturned before apex. Spermathecae two, exceedingly large, irregularly short-oval to reniform, with sclerotised parts of ducts short and curved.

Material examined. Holotype $\delta \overrightarrow{~(o r i g i n a l ~ d e s i g n a t i o n): ~}$ Czech Republic, Moravia, Ŕička valley nr. Brno [6766], 18.v.1918 (K. Czižek leg.) (MMBC), labelled: "Rcziczkatal 18. Mai 1918" (hand-written), "schistacea" (hand-written), "Rhabdomastix subparva sp. n. o J. Starý det. 1969" (partly printed), "Holotypus" (printed, red), "Invent. č. 951/Ent. Mor. muzeum Brno" (partly printed). Two first labels in Czižek's hand. The specimen is micro-pinned on a stage of plant parenchyma; only left fore leg present; abdomen broken off. Terminalia dissected and placed in a corked glass tube with glycerine, pinned with the specimen. Allotype 9 : Czech Republic, Moravia, Adamov [Adamstal] [6665-6765], 17.v.1914 (K. Czižek leg.) (MMBC), with corresponding labels as for holotype. Paratypes: Czech Republic, Moravia, Ŕíčka valley nr. Brno, 18.v.1918, 10ิ, 2 \%; Ochoz [Ochos] nr. Brno [6766], 18.v.1918, 10; Bílovice nad Svitavou [Bilowitz] [6766], 28.v.1913, 10; Adamov, 17.v.1914, 2ㅇ, 2.vi.1914, 3 đิ (all K. Czižek leg.) (all MMBC); Hlubočky nr. Olomouc [6370], 17.v.1969, 1ठ; Hrubá Voda nr. Olomouc [6370], 21.v.1969, 1ơ, 19; Jívová nr. Olomouc [6270], 29.v.1969, 10, 1 ㅇ (all J. Starý leg.) (all JSO). [In the original description (Starý, 1971: 154-158), further paratypes are listed, deposited in other collections.]

Other material examined $(641 \delta, 225 q, 1$ specimen): Switzerland: Canton Vaud: Chabrey (430 m), 23.v.1981, 1 우 (J.-P. Haenni leg.). Canton Valais: Les Giettes, 19.vi.1979, 4ð, 2 우 (W. Geiger leg.). Canton Schaffhausen: Merishausen, 27.v.1980, 1 \% (W. Geiger leg.). Canton Luzern: Werthenstein, 24.v.1980, 20 (W. Geiger leg.). (All MHNN; in ethanol). Germany: Rheinland-Pfalz: River Ahr, "Daubians Mühle", 25.v.1959, 2 ơ (B. Mannheims leg.) (ZFMK). Hessen: Vogelsberg, Gilgbach nr. Rebgeshorn, 27.v.1971, 160, 5 (P. Zwick leg.); Schlitz, Rohrwiesenbach, 14.-31.v.1971, 29ð, 21 ㅇ (San-

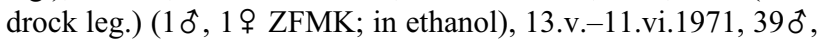
48 (J. Illies leg.); Fulda, Feldbach, 21.v.1971, 10, 2오, 3.vi.1973, 14 ơ; Ostrhön, Krumbach, 1.vi.1977, 1 ठิ, 2 우 (all P. Zwick leg.) (except as stated all JSO; in ethanol). BadenWürttemberg: Schwarzwald Mts, nr. Ottenhöfen, 27.vi.1965, 19 , nr. St. Märgen, 29.v.1965, $3 \delta^{\star}$ (B. Mannheims leg.) (ZFMK). Bayern: Ochsentobel, Kürnach, 31.v.-15.vii.1971,

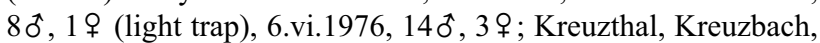
15.v.-17.vi.1971, 53ठ 0 , 10 (light trap), 10.vi.1971, 20ิ, 1 \% Kemptener Wald, ix.1970, $1 \delta^{\hat{x}}$ (all H. Mendl leg.) (all JSO; in ethanol), viii.1973, 250, 6 우 (H. Mendl leg.) (ZFMK; in ethanol); Allgäuer Alpen, Birksau, Ringang im Stillachtal (900

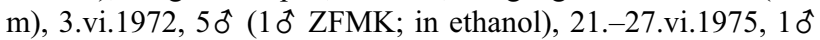
(light trap), 23.-30.vi.1974, 10, 1 ㅇ (light trap), 9.vii.1974, 1 \%; Freiburger Alpe $(1250 \mathrm{~m})$, undated, 10, 19; Lochbachtal, Schwabenalpe $(1200 \mathrm{~m}), 22 . v i .1975,3 \hat{0}$; Traufbachtal (1200-1350 m), 22.vi.1971, 240ิ, 7 ㅇ (all H. Mendl leg.) (except as stated all JSO; in ethanol). Czech Republic: Bohemia: Malenice [6849] (distr. Strakonice), Volyňka shores, 12.v.2003, 40ิ, 2 ㅇ (J. Starý leg.) (JSO). Moravia: Jeseníky Mts, Rejvíz [5769] (700 m), 1.vi.1973, 4ठ, 1\%; Jeseníky Mts, Branná [5868] (700 m), 1.vi.1972, 4ठิ, 1\%, 12.vi.1975, 1ठ, 9.vi.1983, 1ठิ, 1ㅇ, Klepáčský brook, 10.vi.2003, 10ิ, 1 \%, "Dembauda" (900 m), 22.vii.1972, 10, 9.vii.1975, 20, 3ㅇ, 
21.vii.1999, 1 đo; Jeseníky Mts, Malý Kotel [5969], 26.vi.1974, 1ठ; Jeseníky Mts, Velký Kotel [5969], 18.vi.1974, 1ठ 25.vi.1974, 2ơ; Jeseníky Mts, Kouty n. D. [5868], Divoká Desná valley (600-700 m), 2.vi.2003, 10̊; Moravice nr. Malá Morávka [5969], 21.vi.1973, 1 ; Valšov [6070], Moravice valley, 9.vi.1982, 10, 1.vi.1983, 10, 1 + ; Rešov [6169], Huntava valley, 24.v.1985, 10ิ; Dlouhá Loučka [6169], "Valšovský žleb" 12.v.1986, 10 , 28.v.1987, 10ิ, 19; Jívová nr. Olomouc

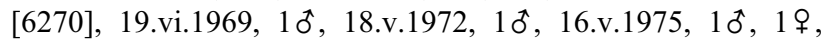
22.v.1975, 1ठิ, 7우 28.v.1975, 3ठิ, 2우 5.vi.1975, 1ठ;

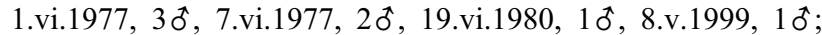

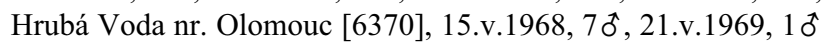
(ZFMK), 13.v.1970, 10, 13.vi.1970, 10, 2ㅇ, 18.vi.1970, 3ठ, 1ㅇ, 19.vi.1970, 20ิ, 22.vi.1970, 10ิ, 27.v.1971, 30ิ, 1 우 (1우 ZFMK), 18.vi.1974, 5ठ, 16.v.1975, 10, 5.vi.1975, 1 \% , 25.v.1977, 1ठ; Hrubá Voda - Smilov [6370], 7.vi.1972, 20; Hlubočky nr. Olomouc [6370], 17.v.1969, 20ิ, 17.v.1970, 5 ô, 1 , 19.v.1973, 4o; Javoříčko [6367], Špranek valley, 4.vi.1987, 10; Čechy pod Kosířem [6468], 29.v.1975, 1 ơ; Nové Oldřưvky [6271], Odra valley, 2.vi.1993, 5ठ, 29 ; Libavá env., Vojnovice [6271], 15.vi.1994, 1ठ; Kletné nr. Suchdol n. O. [6373], 24.v.1975, 10;; Staměřice [6470] (distr. Přerov), 9.v.1981, 10, 13.v.1981, 1ठં; Lazníky nr. Přerov [6470], 22.v.1979, 1 \%, 16.v.1985, 1ㅇ, 18.v.1985, 10, 8.vi.1991, 19, 9.vi.1991, 20ิ, 1.vi.1992, 1 \%; Nýdek [6378], Hluchová valley, 20.vi.1996, 20 , 1+; Vlčovice nr. Kopřivnice [6475], Tichávka shores, 6.vi.2001, 1 ठ̊̃; Vyšní Lhoty [6376], Morávka shores, 8.vi.1995, 1ㅇ, 21.v.1996, 1ठ, 30.v.1996, 1ठ, 1ㅇ, 19.vi.1996, 1ㅇ, 3.vi.1998, 1ठิ, 10.vi.1998, 1 ठิ, 24.v.2000, 6ठ, 2ㅇ, 17.v.2001, 60ิ, 1̊; Trojanovice [6475], Bystrá valley, 15.vi.1989, 10ิ, 1 \$; Moravskoslezské Beskydy Mts, Mionši brook [6477], 28.v.1985, 1ठో; Moravskoslezské Beskydy Mts, Prostř. Bečva, "Malinová" [6575] (700-800 m), 27.vi.1991, 2q; Hostýnské Hills, "Bernardka" [6672] (500 m), 12.vi.1992, 10; Kašava [6772], Dřevnice valley, 14.v.1985, 60; Adamov, "Býčí skála" [6666], 26.v.1973, 20ิ, 1\%; Brno, "Kočičí žleb" [6764], 21.v.1974, 4ô, 1ㅇ, 9.v.1977, 2ðิ, 19, 22.v.1977, 4ơ; BrnoRečkovice [6765], 9.v.1972, 10े; Brno, Bobrava valley, 10.v.1968, 30ิ, 10.v.1969, 20ิ, 9.v.1971, 1 đ; Náměšt' n. O., Oslava valley [6863], 26.v.1983, 20ิ, 19; Podhradí n. Dyjí [7159], Dyje valley, 4.vi.1999, 1ठ; Hnanice nr. Znojmo [7161], Dyje valley, 30.v.1995, 20ิ, 1\%; Znojmo [7161], Dyje valley, 29.v.1977, 2 ơ; Radějov [7170], Radějovka valley, 30.iv.1983, 10ิ, 14.v.1983, 2 ô, Lučina, 5.vi.1980, 1 ô, Měsíční údolí [valley], 20.v.1981, 1 đิ (all J. Starý leg.) (except as stated all JSO). Slovakia: Súlov, 3.vi.1970, 2 đ (R. Rozkošný leg.); Trstín [7470], "Pustatina", 4.vi.1974, 3ð, 1\%; Malé Karpaty Mts, Smolenice [7570], "Jahodník", 2.vi.1974, 50ิ, 5.vi.1974, 60ે, 6; Turany [6880], peat-bog, 11.vi.1987, 1ठ; Stankovany

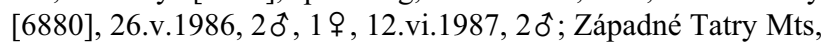
Oravice, Tichá dolina [valley] [6784] (800-850 m), 12.vi.2000, 3 ô, 14.vi.2000, 2 ô, Juráňova dolina [valley], "Tiesňavy” (880 m), 15.vi.2000, 10, 1 9 ; Západné Tatry Mts, Račková dolina [valley] [6884], 16.vii.1967, 1 \% (all J. Starý leg.); Pribylina nr. L. Mikuláš [6884], 9.vi.1970, 10 (J. Martinovský leg.); Belianske Tatry Mts, dolina Siedmich prameňov [valley] [6787], 30.vii.1974, 1 đิ (J. Starý leg.); Belianske Tatry Mts, Tatranská Kotlina, "Kardolina" [6788] (750 m), 23.v.1975, $1 \delta^{\widehat{0}}$ (J. Martinovský leg.), 2 ㅇ (J. Starý leg.); Belianske Tatry Mts, Tatranská Kotlina, Belá valley [6788] (750 m), 22.vi.1975, 1 \%, 27.vi.1975, 1ठ, 18.vi.1977, 1ðð; Lendak [6788], Belá valley, 5.vii.1978, 1ठ̛; Pieniny Mts, Červený Kláštor, Dunajec valley [6588], 30.v.2000, 10ิ; Slovenské Rudohorie Mts, Úhorná [7289], 11.vii.1970, 1\%; Muráň env. [7286], 8.vi.1984, 1ठ, Hrdzavá dolina [valley], 18.vi.1981, 10, 14.vi.1982, 20; Krupinská Upland, Litava valley nr. Cerovo [7780], 2.vi.1997, 6ठิ,
1 \%; Pol'ana Mts, Kyslinky [7382], Hučava valley (750 m) [7382], 20.vi.2003, 19 ; Pol'ana Mts, "Hronček ponds" [7383] (650 m), 10.vi.1999, 10ิ, 2q; Pol'ana Mts, "Hrončecký grún̆" [7383], 10.vi.1999, 10; Pol'ana Mts, Predná Pol'ana, Bystré waterfall [7482], 6.vii.2000, 1\%; Blhovce nr. Rim. Sobota [7785], 22.v.1980, 1ठ; Hostovice [6898], Udava shores, 16.vi.1986, 1ठ, 19.v.1987, 1ठ; Stakčín, Chotinka valley [6999], 3.vi.1984, 10, 4.vi.1984, 20, 2.vi.1985, 10; Bukovské Hills, Ruské [6800], Cirocha shores, 3.vi.1985, 40ิ, 1 \% , 7.vi.1985, 2 đ̛; Bukovské Hills, Nová Sedlica [6901], "Stužica", 13.vi.1986, 3 ô, 1ㅇ, 15.vi.1991, 1 ㅇ, 20.vi.1991, 1 đ, 1 ㅇ․ Nová Sedlica env., 6.vi.1984, 10ิ, 5.vi.1985, 10ิ, 1 우, 6.vi.1988, 1ठ, 8.vi.1988, 20, 13.vi.1991, 1 đ, 1 ㅇ, Nová Sedlica, Zbojský brook [6900], 21.vi.1991, 1ठ; Vihorlat Mts, Sninský Kameň [7099], 19.v.1987, 1 đo (all J. Starý leg.) (all JSO). Austria: “Alte Sammlung”, 10 (J.R. Schiner leg.) [listed as schistacea by Lackschewitz, 1940] (NHMW). Tirol: Lechleiten (1500 m), 22.vi.1974, 1 ठ (H. Mendl leg.); Axamser Bach, 19.vi.1974, 1 ô (H. Malicky leg.) (all JSO; in ethanol); above Imst, 6.vii.1969, 1ठ; Kufstein, 1.vi.1969, 1ठ; nr. Jochberg, 1.vi.1969, 2 ऊิ (all B. H. \& M.C. Cogan, R.I. \& R. Vane-Wright leg.) (all BMNH). Steiermark: Leoben $(830 \mathrm{~m}), 10^{\hat{\alpha}}$ (R. Wagner leg.) (JSO; in ethanol). Oberösterreich: Grünbach nr. Freistadt,

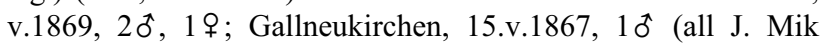
leg.); Freistadt, 7.v.1981, $1 \delta^{\star}$ (A. Handlirsch leg.) [all listed as schistacea by Lackschewitz, 1940] (NHMW). Niederösterreich: Pötzleinsdorf, 10 (J.R. Schiner leg.) [listed as schistacea by Lackschewitz, 1940] (NHMW). Burgenland: Kaisersteinbruch, 14.v.1924, 3 ô (H. Zerny leg.) [listed as schistacea by Lackschewitz, 1940] (NHMW). Kärnten: Millstätter See (1000 m), Sappl-Bach, 20.vi.1976, 3ठे, 1\%; Weissensee (1200 m), 21.vi.1976, 20 (all R. Wagner leg.) (all JSO; in ethanol). Niederösterreich: Gutenstein env., 17.v.1994, $1 \hat{0}$ (J. Starý leg.) (JSO). Italy: Trentino-Alto Adige: Val d'Ampola, 3.vi.1971,

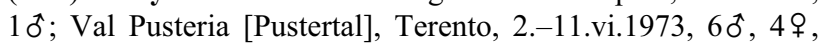
25.v.1974, 7ठิ, 1\%, 1.vi.1975, 17ठ, 3; "Winnebachtal" nr. Terento, 26.v.1974, $4 \sigma^{\star}$ (all H. Mendl leg.) (all JSO; in ethanol), "Fuchsstein" (1550 m) nr. Terento, 2.-11.vi.1973, 67ठ, 16우, "Erdpyramiden" nr. Terento, 2.vi.1973, 1 đo, 1 우 (H. Mendl leg.) (ZFMK; in ethanol); Val Gardena [Grödner Tal], Orisei [St. Ulrich] (1240 m), 12.vi.1973, 140, 1 $\%$; Passo di Gardena [Grödner Pass] (2600 m), 12.vi.1973, 20; Passo Pordoi ( 2100 $\mathrm{m}), 8 \hat{\delta}, 3$ ㅇ (all H. Mendl leg.) (all JSO; in ethanol). FruiliVenezia Giulia: Gorizia [Görz], 19.iv.1864, 1 ㅇ, 14.v.1865, 1 운, 1 specimen (J. Mik leg.) [listed as schistacea by Lackschewitz, 1940] (NHMW). Slovenia: "Tarnovaner Wald", 25.vi.1864, 10 (J. Mik leg.) [listed as schistacea by Lackschewitz, 1940] (NHMW). Romania: between Bucurest and Brasov, 6.vi.1978, 10 (R. Wagner leg.) (JSO; in ethanol). Bulgaria: Pirin Mts, Lilianovo nr. Sandanski, 6.v.1989, 3 ô, 1 † (J. Starý leg.) (JSO). Ukraine: Zakarpatskaya oblast: Vel. Berezniy env., 25.v.1974, 20, 1; Osoy env., 7.vi.1969, 10, 6.vii.1969, 20; Bogdan env., 4.vii.1969, 1ठิ, 5.vii.1969, 1\%; Kosova Polyana env., 1.vi.1974, 20, 1 우 (all E. N. Savchenko leg.). Chernovitskaya

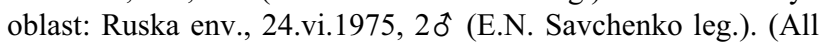
JSO). Russia (Europe): Krasnodarskiy kray: Nebuch env., 22.v.1963, 1 우 (E. N. Savchenko leg.) (JSO).

Discussion. This is the commonest and largely eurytopic species in Central Europe, practically invariable in the body colouration and clearly distinct from all the other species treated in a number of both external and genital characters. $R$. (R.) subparva is, on the average, the largest and slightly more slender species in general appearance than any others of the $R$. (R.) edwardsi com- 
plex, thus actually representing the opposite of $R$. $(R$.) crassa sp. n. $R$. (R.) subparva has, e.g., the wing stalk and halter rather long, the latter reaching to about the posterior margin of the abdominal tergite 2 (Fig. 16) (shorter in all related species, cf. Fig. 15). The numerous macrotrichia on $\mathrm{R}_{4}$ likewise are unique within the complex. The dark greyish brown body colouration combined with yellow coxae is only present in the Central European specimens of $R$. (R.) eugeni $\mathrm{sp}$. $\mathrm{n}$. The male terminalia of $R$. (R.) subparva are characterised by an evenly arched outer gonostylus tapered distally and provided with a distinct apical spine, and by a generally slender aedeagal complex with a narrow vesica and a rod-like apodeme. The female terminalia are distinctive in having rather broad, abruptly upturned cerci and, especially, two shortoval, exceedingly large spermathecae.

Distribution. The species was described comparatively recently, at the time when more attention was paid to small dark Rhabdomastix $\mathrm{s}$. str. species, previously lumped under "schistacea". Therefore, it may be assumed that most of the country records published by Savchenko et al. (1992) are correct. These are as follows: Switzerland, Germany, Poland, Czech Republic, Slovakia, Austria, Ukraine, Italy, the former Yugoslavia (Slovenia, Serbia), Albania (?), Romania and Bulgaria (modified according to the present political boundaries). Based on the material examined, the species is here confirmed for Switzerland, Germany, Czech Republic, Slovakia, Austria, Italy, Slovenia, Romania, Bulgaria and Ukraine, and newly recorded for European Russia (southeast). Not confirmed from Poland, Serbia or Albania.

\section{Rhabdomastix (Rhabdomastix) hirticornis (Lackschewitz, 1940)}

(Figs 11-13, 40, 42, 54)

Gonomyia (Rhabdomastix) hirticornis Lackschewitz, 1940: 55 (description), Tab. 3, Figs 28a-b (male terminalia), c (wing), $\mathrm{d}$ (male antenna).

Rhabdomastix hirticornis: Mannheims, 1967: 473 (faun. record); Starý \& Geiger, 1998: 73 (synonymy with signata, list).

Rhabdomastix (Palaeogonomyia) hirticornis: Savchenko, 1976: 563, 564 (diagnosis, faun. record), Figs 1b (wing), 2b (male terminalia); Mendl, 1979a: 355, 363 (synonymy with signata); Savchenko, 1982: 274 (redescription, faun. record), Figs 130/1 (wing), 133/1 (general view), 135/1 (male terminalia); Krzemiński, 1984b: 461 (diagnosis, faun. record), Figs 51 (male antenna), 52 (male terminalia); Erhan-Dinca \& Ceianu, 1986: 89 (faun. record in list); Savchenko, 1989: 263 (faun. record), Fig. 133/1 (male terminalia); Savchenko et al., 1992: 314 (Palaearctic catalogue, synonymy with signata); Oosterbroek \& Starý, 1995: 7 (list); Starý \& Oosterbroek, 1996: 72 (faun. record); Starý, 1997: 13 (list); Starý, 2001: 186 (faun. record).

Rhabdomastix (Rhabdomastix) hirticornis: Mendl, 1978: 373 (list).

Rhabdomastix (Sacandaga) hirticornis: Starý, 1987: 20 (list) [deleted; see Starý, 1993: 123]; Krzemiński, 1991: 80 (list); Starý, 1995: 30 (faun. record).

Rhabdomastix (Rhabdomastix) signata Bangerter, 1947: 377 (description), Figs 20a (thorax), b (wing), c (male antenna).

Rhabdomastix signata Bangerter, 1943: 20 (faun. record) [nomen nudum]; Bangerter, 1946: 192 (faun. record) [nomen nudum].
Diagnosis. General colouration grey on thorax, more brownish on abdomen. Male antenna very long, subequal to entire body. Wing narrow, slightly infuscated. $\mathrm{A}_{2}$ ending before origin of Rs. Legs yellowish brown to brown, with yellow coxae. Male terminalia with outer gonostylus gently arched, club-shaped, with apical spine not apparent; apical blade of interbase spoon-shaped. Female terminalia with three reniform, medium-sized spermathecae.

Redescription. Rather small species, yet somewhat larger than many others described here as "small". Body length 4-6.5 mm, wing length 5-7 $\mathrm{mm}$.

Colour. General colouration grey to light grey, dull, without conspicuous markings on thorax, sometimes more brownish in middle of prescutum and still more so on abdomen. Antenna dark brown throughout. Pleuron heavily suffused with bluish grey pruinosity. Wing slightly infuscated. Halter dirty white to pale yellow, with knob faintly infuscated. Coxae yellow to yellowish brown, fore coxa more greyish. Trochanters and proximal half of femora yellow, the latter darkened distally. Rest of legs yellowish brown. Abdomen greyish brown to pale brown.

Head. Male antenna (Fig. 11) very long, subequal to entire body. Flagellomeres very long, first one rather conical, following ones cylindrical, longest near midlength of antenna, terminal flagellomere minute. Verticils inconspicuous, about one-fourth to one-fifth length of their respective segments, distinct at base of eight proximal flagellomeres, largely getting lost among greatly developed erect pubescence subequal to one-third length of longest flagellomeres. Female antenna (Fig. 12) considerably shorter than that of male, yet distinctly longer than antenna of any other species treated here (except for male of georgica), extending beyond base of wing by about one-fourth of its length. Flagellomeres mostly elongate-oval, progressively narrowed towards apex of antenna. Verticils on flagellomeres slightly shorter than their respective segments. Pubescence indistinct. Palpus long, distinctly exceeding diameter of head; terminal palpomere nearly twice as long as penultimate (Fig. 13).

Thorax. Wing rather long and narrow, about four to five times as long as broad, with comparatively short stalk. $\mathrm{Sc}_{1}$ ending at about half length of $\mathrm{Rs} . \mathrm{Sc}_{2}$ faintly apparent at tip of $\mathrm{Sc}_{1} . \mathrm{R}_{3}$ more than its own length beyond tip of $R_{1}$. $R_{4}$ with numerous macrotrichia, about 20 , both dorsally and ventrally. $\mathrm{A}_{2}$ sinuous, ending far before origin of Rs. Halter appearing rather long, but not reaching to posterior margin of abdominal tergite 2 .

Abdomen. Male terminalia (Fig. 40). Segment 9 longer than broad. Gonocoxite moderate in length and breadth. Outer gonostylus more than half length of gonocoxite, generally slender, club-shaped, gently and evenly arched, slightly broadened before apex, with apical spine mostly not apparent, concealed by expanded apical portion of gonostylus. Inner gonostylus somewhat swollen, with short obtuse point. Aedeagal complex as in Fig. 40. Interbase comparatively long, extending beyond half length of gonocoxite, expanded distally to form spoon-like apical 
blade, sometimes pointed at apex. Aedeagus slender, longer than comparatively narrow vesica. Apodeme of vesica short, mostly spine-like from dorsal aspect, shorter than vesica. Female terminalia (Figs 42, 54). Cercus slender, rather long, longer than tergite 10, gently upturned. Spermathecae three, medium-sized, short-oval to reniform, with sclerotised parts of ducts short, somewhat curved. One spermatheca sometimes smaller than other two.

Material examined. Gonomyia (Rhabdomastix) hirticornis: Lackschewitz (1940) described this species from an unspecified number of males and a single female, all from Albania. At present, $5 \hat{\sigma}$ (from Kula Ljums) and 19 (from Bicaj) are deposited in NHMW (R. Contreras-Lichtenberg, e-mail comm.). I examined one male and the female. The males were nominated "Typen!" by Lackschewitz (1940: 56), but the female was not. Hence, the latter is excluded from the type series (cf. ICZN, Article 72.4.6.) and cannot become a paralectotype. Lectotype đo (present designation): Albania, Kula Ljums, 18.-28.v.1918 (H. Zerny leg.) (NHMW), labelled: “Alban. Exped. Kula Ljums 18-28.V.'18" (printed), "Rhabd. hirticornis nov. sp. det. Lacksch." (printed, orange). Accordingly labelled as lectotype ["Lectotype Rhabdomastix (s. str.) hirticornis (Lacksch.) ô J. Starý 2003"; printed red label]. The specimen is pinned, with right mid leg attached, two other legs glued onto a white cardboard point below the specimen; apex of abdomen cut off. Terminalia preserved in Canada balsam between celluloid slides, pinned with the specimen. The specimen is designated here as lectotype to maintain the current usage of the name.

Rhabdomastix (Rhabdomastix) signata: Holotype of (original designation), 2.viii.1940, and allotype $\$$, 15.vi.1943, from Switzerland, Canton Bern, "Obere Sense zwischen Thörishaus und Grasburg, Viadukt" (H. Bangerter leg.; in ethanol) (NHBB). I examined the specimens in 1976 (cf. Mendl, 1979: 363).

Other material examined $(37 \hat{\sigma}, 66 q)$ : Switzerland: Canton Ticino: Gordevio, middle vi.- early ix.1980, 1 우 (L. Rezbanyai leg.; Malaise light trap) (MHNN; in ethanol); Contra nr. Locarno (520 m), 30.vi.1972, 1 \% (P.H. Arnaud, Jr. leg.) (ZMAN). Germany: Bayern: Kreuzthal, 22.-27.vii.1972, 2 우 (H. Mendl leg.; light trap) (ZFMK; in ethanol); Kreuzthal, 10.-17.viii.1972, 19 (light trap); Kempten (shop window), 12.vii.1971, 1 i (all H. Mendl leg.) (all JSO; in ethanol). Poland: Beskid Wyspowy Mts, Kasinka, Raba valley, 27.vi.1970, $1 \delta^{\widehat{T}}$ (A. Kowacki leg.) (ISEZ). Czech Republic: Moravia: Vyšní Lhoty [6376], Morávka shores, 17.vi.1999, 1 o, 26.vii.1999, 15 ㅇ (at light), 9.v.2000, 2 우 (at light), 17.v.2001, 7 (at light), 4.vi.2002, 1 ( J. Starý leg.) (JSO). Slovakia: Belianske Tatry Mts, Tatranská Kotlina, Belá valley [6788] (750 m), 23.vi.1975, 1 $9,27 . v i .1975,19,18 . v i i .1975,19$ (J. Starý leg.) (JSO); Hostovice, Udava shores, 16.vi.1980, 1 (J. Starý leg.) (ZFMK; in ethanol). Snina, Cirocha shores [7099], 19.vi.1983, 5ô, 1 9 , 22.vi.1983, 20, 2.vi.1984, 1ㅇ, 1.vi.1985, 20; Bukovské Hills, Ruské [6800], Cirocha shores, 7.vi.1985, 10ิ, 1 ; Bukovské Hills, Nová Sedlica [6901], Zbojský brook, 8.vi.1988, 2q; Bukovské Hills, Zboj [6900], Zbojský brook,

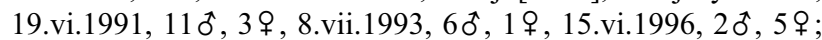
Bukovské Hills, Krivé [7000], Zbojský brook, 17.vi.1991, 1 ㅇ (all J. Starý leg.) (all JSO). Austria: Niederösterreich: Grossraming, 21.vii.+4.viii.1983, 10, 3 우 (H. Malicky leg.) (ZFMK; in ethanol). Albania: Bicaj, 14.-15.vi.1918, 1 우 (H. Zerny leg.) (NHMW) [excluded from the type series, see above]. Bulgaria: Sandanski, Lebnitsa valley, 6.v.1989, 10ิ, 7.v.1989, 10ิ,

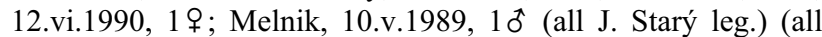
JSO). Greece: Platamon, Prov. Katerini, Castle-Camping, 7.-14.vi.1968, 1 ㅇ (B. Mannheims leg.; at light) (ZFMK); Voutouasi, NE Joannina, 16.v.1978, 1 † (G. Theischinger leg.); Lilaia, 29.vi.1976, 1 (H. Malicky leg.) (both ZFMK; in ethanol); Thasos Is., Ipsarion (1000 m), 6.vi.1973, 3 ㅇ (H. \& U. Aspöck, H. Rausch \& P. Ressl leg.); Evvoia Is. [Euböa, Euboeia], S Prokopion (250 m), 24.v.1974, 2 ㅇ (H. Malicky leg.); Chios Is., N Kalamoti (250 m), 18.v.1973, 1 우 (collector unknown) (all JSO; in ethanol). Ukraine: Chernovitskaya oblast: Zhadova Nova env., Seret valley, 4.vi.1974, 1 \% ; Komarovka env., Seret valley, 22.vi.1975, 2 q (all E.N. Savchenko leg.) (all JSO). Algeria: Chiffy, "Monkey Valley", 18.iv.1981, 10ิ, 19.iv.1981, 2 o (W. Krzemiński leg.) (JSO).

Discussion. Members of Central European populations are distinctly darker than specimens from the Balkans (including the type series). The latter are more pronouncedly bicoloured, having a light grey thorax and a pale brown abdomen. This may be the case for other southern regions of Europe, as indicated by several specimens from southern Ukraine and a dry-mounted female from southern Switzerland (Ticino). On the other hand, the examined specimens from Algeria are still darker than those from Central Europe. There is a certain variation in the shape of the outer gonostylus; the apical spine is sometimes well apparent (cf. Lackschewitz, 1940, Tab. 3, Figs 28a, b), which, however, may be an artefact caused by compression of the hypopygium between the celluloid slides.

From all the species treated (except georgica), males of $R$. (R.) hirticornis may at once be separated by the long antennae (Fig. 11). The problem of long antennae in Rhabdomastix was discussed in some detail in the first part of this revision (Starý, 2003) and it is again mentioned in the discussion of the species complexes above. Due to the bicoloured appearance, females of $R$. (R.) hirticornis from South Europe may be confused with $R$. (R.) filata sp. n. or South European specimens of $R$. $(R$.) eugeni sp. n. It should, however, be emphasised that females of $R$. (R.) hirticornis are also clearly separable by the structure of the antennae. These are considerably shorter than those of males, yet distinctly longer than the antennae of any other species treated (Fig. 12). The long palpi in both sexes of $R$. (R.) hirticornis, distinctly exceeding the diameter of the head, with the terminal palpomere nearly twice as long as the penultimate, represent another distinguishing character (Fig. 13) (in the other species treated, except georgica, the palpi are short, subequal to the diameter of the head, with the terminal palpomere only slightly longer than the penultimate, cf. Fig. 14). The considerable distinctness of the male antennae in $R$. $(R$.) hirticornis is not reflected in the structure of the male terminalia, which provide no essential differences as compared to the other species, and only differ by details, such as the overall shape of the outer gonostylus and the structure of the aedeagal complex. The female terminalia of $R$. (R.) hirticornis are well characterised by three reniform, medium-sized spermathecae. Differentiating between $R$. (R.) hirticornis and $R$. (R.) georgica $\mathrm{sp}$. n. is covered in the discussion of the latter species.

Distribution. Records of the species are available from Switzerland, Poland, Slovakia, Albania, Romania and Ukraine 

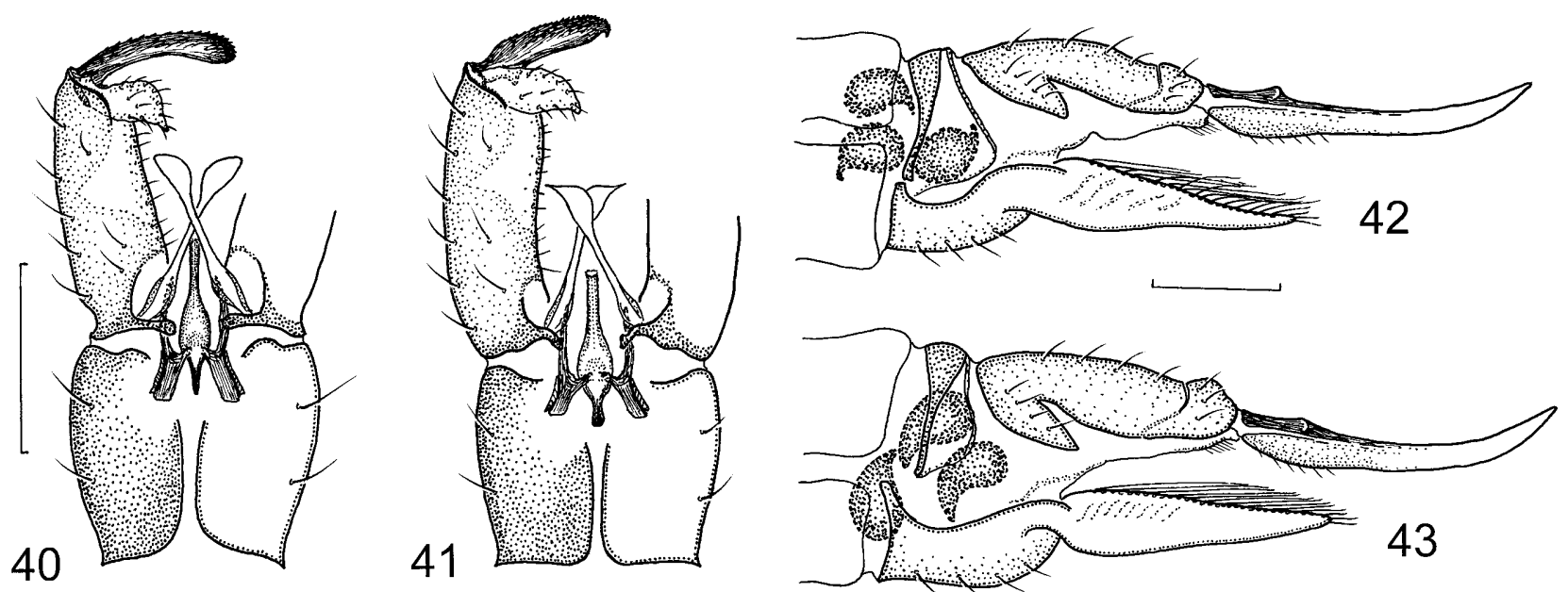

Figs 40-43. 40-41. Male terminalia, general view, dorsal. 40 - Rhabdomastix (Rhabdomastix) hirticornis (Lackschewitz, 1940) (Slovakia: Zboj); $41-R$. (R.) georgica sp. n. (holotype). 42-43. Female terminalia, general view, lateral. $42-R$. (R.) hirticornis (Lackschewitz, 1940) (Slovakia: Zboj); $43-R$. (R.) georgica sp. n. (paratype, Georgia: Goderzi Pass). Scale bars $0.25 \mathrm{~mm}$.

(Savchenko et al., 1992). Subsequently recorded from Italy (Sicily) (Oosterbroek \& Starý, 1995, Starý \& Oosterbroek, 1996) and quite recently from the Czech Republic (Starý, 2001). Most of the records are confirmed here, except Italy (Sicily) and Romania. Newly recorded for Germany, Austria, Bulgaria, Greece and Algeria.

\section{Rhabdomastix (Rhabdomastix) georgica sp. n.}

(Figs 41, 43, 55)

Diagnosis. General colouration dark greyish brown. Male antenna very long, longer than entire body. Wing narrow, infuscated. $\mathrm{A}_{2}$ ending before origin of Rs. Legs yellowish brown to brown, with coxae yellowish brown. Male terminalia with outer gonostylus straight, with distinct apical spine, and apical blade of interbase triangular, with sharp point at inner margin. Female terminalia with three reniform, large spermathecae.

Description. Small species, subequal in size to $R$. $(R$.) hirticornis. Body length 5-6 mm, wing length 4.5-6 mm.

Colour. General colouration dark greyish brown, dull, without conspicuous markings on thorax, more brownish on abdomen. Antenna brown throughout. Pleuron heavily suffused with grey pruinosity. Wing infuscated. Halter infuscated, especially on knob. Coxae yellowish brown, fore coxa more greyish pruinose. Trochanters and femora yellowish brown, the latter darkened distally. Rest of legs yellowish brown to brown.

Head. Male antenna very long, longer than entire body. Flagellomeres very long, first one rather conical, following ones cylindrical, longest near mid-length of antenna, terminal flagellomere minute. Verticils indistinct. Pubescence, long, erect, rather sparse, subequal to one-third length of longest flagellomeres. Female antenna considerably shorter than that of male, not reaching to base of wing. Flagellomeres oval to elongateoval, rather thin, not noticeably changing in size towards apex of antenna. Verticils on flagellomeres shorter than their respective segments. Pubescence indistinct. Palpus long, distinctly exceeding diameter of head; terminal palpomere nearly twice as long as penultimate.

Thorax. Wing long and narrow, about five times as long as broad, with long stalk. $\mathrm{Sc}_{1}$ ending at about half length of Rs. $\mathrm{Sc}_{2}$ faintly apparent shortly before tip of $\mathrm{Sc}_{1}$. $\mathrm{R}_{3}$ more than its own length beyond tip of $\mathrm{R}_{1} . \mathrm{R}_{4}$ with numerous macrotrichia both dorsally and ventrally. $\mathrm{A}_{2}$ long, sinuous, ending before origin of Rs. Halter comparatively short, not reaching to posterior margin of abdominal tergite 2 .

Abdomen. Male terminalia (Fig. 41). Segment 9 longer than broad. Gonocoxite moderate in length and breadth. Outer gonostylus slightly more than half length of gonocoxite, gently bent at base, otherwise straight, nearly parallel-sided, with apical spine distinct. Inner gonostylus generally conical. Aedeagal complex as in Fig. 41. Interbase comparatively long, extending beyond half length of gonocoxite, with apical blade generally triangular, drawn out into sharp long point at inner distal margin, directed laterally. Aedeagus subequal in length to comparatively narrow vesica. Apodeme of vesica short, spine-like or somewhat bulb-shaped at apex from dorsal aspect, shorter than vesica. Female terminalia (Figs 43, 55). Cercus slender, rather long, longer than tergite 10 , gently upturned. Spermathecae three, large, reniform and considerably narrowed in portion closer to duct, practically without sclerotised parts of ducts.

Material examined. Holotype $\delta$ : Georgia (Transcaucasia), Arsianskiy khrebet [mountain ridge], E slopes of Goderdzi Pass (1450-1500 m), 28.vi.1978 (E.N. Savchenko leg.) (SMOC). Except for a printed inscription "Transcriptio" the data on the label are hand-written in Russian (in Cyrillic). The specimen (originally papered) is glued onto a triangular cardboard point, in nearly perfect condition, with only wings somewhat crumpled and stuck together and apex of abdomen missing. Terminalia dissected and placed in a sealed plastic tube with glycerine, pinned with the specimen. Paratypes: $3 \hat{\sigma}, 1+$, same data as for holotype (JSO). 
Etymology. The name of the new species, georgica, is derived from the name of the country of its occurrence, Georgia in Transcaucasia. The name is deemed to be and to be treated as a latinised adjective in nominative singular, in accordance with relevant provisions of the Article 11.9 of ICZN (1999).

Discussion. $R$. (R.) georgica sp. n. is described from Georgia in Transcaucasia, hence from outside of Europe, representing thus an extra-limital species in terms of this revision. It was included here because of its affitinies to $R$. (R.) hirticornis. Within the Palaearctic Region, only three other Rhabdomastix species are known to be distinguished by correspondingly long male antennae, viz. $R$. (R.) hirticornis, Lackschewitz, 1940 (Europe), R. (R.) leucophaea Savchenko, 1976 (Transcaucasia: Azerbaijan) and $R$. (R.) omeina Alexander, 1932 (China: Sichuan), all formerly classified in the subgenus Palaeogonomyia (cf. Savchenko et al., 1992). In the latter two species the antennae are shorter than the body. Five Oriental species with greatly lengthened male antennae (himalayensis Alexander, 1960; manipurensis Alexander, 1964; nilgirica Alexander, 1949; schmidiana Alexander, 1958; trochanterata Edwards, 1928) all belong to the group centred around $R$. illudens Alexander, 1914, as discussed in the first part of this revision (Starý, 2003: 590), with the male antennae several times as long as the body.

$R$. (R.) georgica $\mathrm{sp}$. n. apparently is closely related to $R$. $(R$.) hirticornis. It differs from Central European specimens of the latter by somewhat darker body colouration as well as having longer male antennae, which, in $R$. $(R$.) georgica sp. n., exceed the length of the entire body (subequal in length to the body in hirticornis). However, the female antennae of $R$. $(R$.) georgica sp. n. are shorter than those of $R$. (R.) hirticornis, not reaching to the bases of the wings (extending beyond the bases of the wings in hirticornis). The male terminalia of $R$. (R.) georgica sp. n. are characterised by a generally straight outer gonostylus, nearly parallel-sided, with the apical spine distinct (evenly arched in hirticornis, club-shaped at apex, without a distinct apical spine), and by the interbases with the apical blade triangular, drawn out into a sharp long point at inner margin (apical blade of interbases generally spoon-like in hirticornis). The female terminalia are distinctive in having the spermathecae comparatively large, reniform (smaller in hirticornis, often short-oval).

Distribution. Transcaucasia: Georgia.

\section{Rhabdomastix (Rhabdomastix) beckeri (Lackschewitz, 1935)}

(Figs 3, 10, 44-45, 56)

Sacandaga Beckeri Lackschewitz, 1935: 13 (description), Tab. 2, Figs 6a-b (male terminalia), c (wing).

Rhabdomastix beckeri: Edwards, 1938: 113 (key).

Rhabdomastix (Sacandaga) beckeri: Starý, 1987: 20 (list) [deleted; see Starý, 1993: 123, 1996: 119]; Savchenko, 1989: 264 (note); Savchenko et al., 1992: 315 (Palaearctic catalogue).

Diagnosis. General colouration grey throughout. Antenna short. Wing moderately broad, somewhat milky, with narrow darker seams along veins. $\mathrm{A}_{2}$ ending opposite to origin of Rs. Legs yellow to yellowish brown, femora darkened distally. Male terminalia with outer gonostylus unusually short and broad, inner gonostylus swollen, broadly rounded at apex and aedeagal complex generally slender. Female terminalia with three spherical, medium-sized spermathecae.

Redescription. Medium-sized species. Body length 4-7 mm, wing length $4.5-8 \mathrm{~mm}$.

Colour. General colouration grey, dull, restrictedly tinged with brownish, without conspicuous markings on thorax. Antenna deep dark brown to black throughout. Pleuron heavily suffused with grey pruinosity. Wing slightly infuscated, somewhat milky, most veins vaguely and very narrowly seamed with darker. Halter bright pale yellow. Coxae, trochanters and proximal half of femora yellow, the latter darkened distally. Tibiae yellowish brown, tipped with darker. Tarsomere 1 yellowish brown, others darker. Abdomen a little darker than thorax, greyish brown.

Head. Antenna (Fig. 10) comparatively short, not reaching to base of wing. Flagellomeres short-oval. Longest verticils on flagellomeres slightly exceeding length of their respective segments. Pubescence rather long, suberect, subequal in length to breadth of respective segments, or slightly less so, distinct on almost all flagellomeres. Palpus short.

Thorax. Wing (Fig. 3) moderately broad, more than three times as long as broad, with short stalk. $\mathrm{Sc}_{1}$ ending at about half length of $\mathrm{Rs}$. $\mathrm{Sc}_{2}$ faintly apparent shortly before tip of $\mathrm{Sc}_{1} . \mathrm{R}_{3}$ more than its own length beyond tip of $\mathrm{R}_{1} . \mathrm{R}_{4}$ with a few macrotrichia dorsally. $\mathrm{A}_{2}$ strongly sinuous, ending opposite to origin of Rs. Halter short, clearly not reaching to posterior margin of abdominal tergite 2 .

Abdomen. Male terminalia (Fig. 44). Segment 9 very short, broader than long, with conspicuous, more or less triangular lobe dorsally at posterior margin on each side of median interruption. Gonocoxite stout, short and broad. Outer gonostylus unusually short and broad, somewhat flattened at base, about one-third length of gonocoxite, subequal in length to inner gonostylus, nearly straight and parallel-sided, with distinct apical spine. Inner gonostylus very broad, swollen, broadly rounded at apex. Aedeagal complex as in Fig. 44. Interbase reaching to about half length of gonocoxite, generally slender, sinuous and only faintly dilated distally. Aedeagus very slender and rather long, about 1.5 times as long as moderately broad vesica. Apodeme of vesica rod-like or spinelike in dorsal aspect, about same length as vesica. Female terminalia (Figs 45, 56). Cercus broad, subequal in length to tergite 10 , generally straight, expanded and abruptly upturned before apex. Spermathecae three, rather large, spherical, with sclerotised parts of ducts thin and long, exceeding spermathecal diameter.

Material examined. The species was described from an unspecified number of males ["Banat, Orsova. Im Juni, ô $\widehat{o}$, leg Th. Becker no. 61829. (Typ. in der Samml. des Zool. Museums in Berlin.)" (Lackschewitz, 1935: 13)]. I have examined two specimens that may be considered syntypes. Lectotype $\delta$ (present designation): Romania, [Banat], Orsova, vi., (Th. Becker leg.) (ZMHB), labelled: "Orsova 61829. VI." (hand-written), 


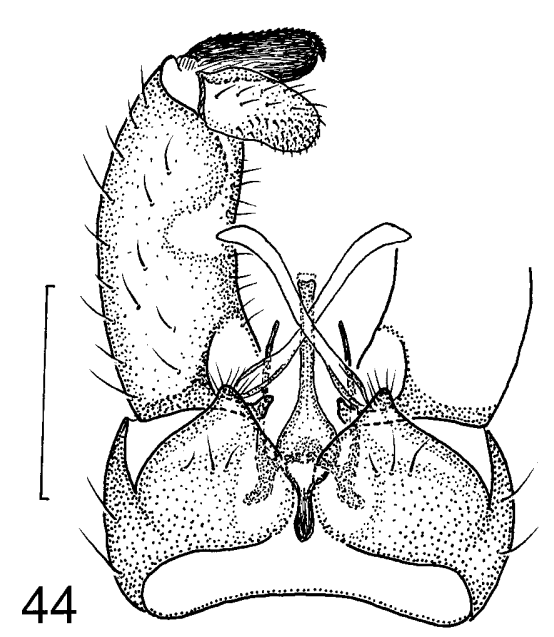

46

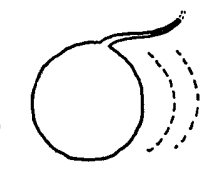

47

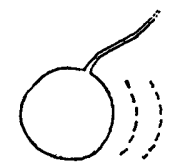

48

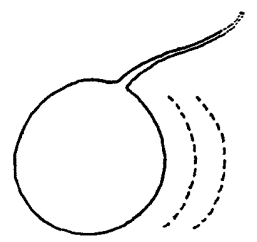

49
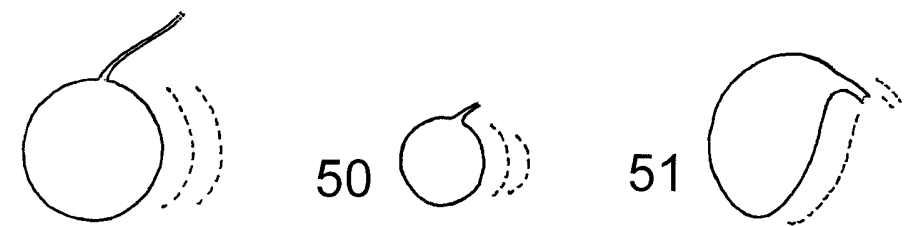

52
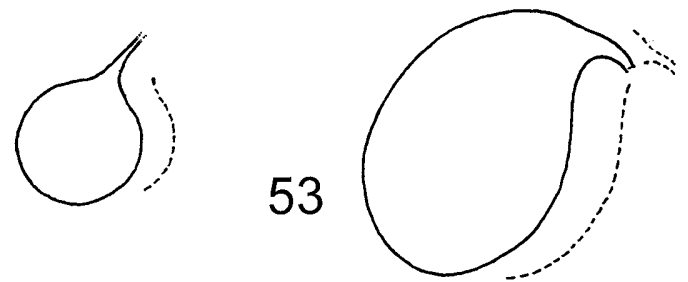

54

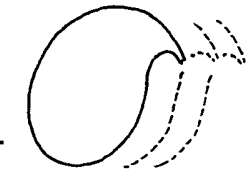

55
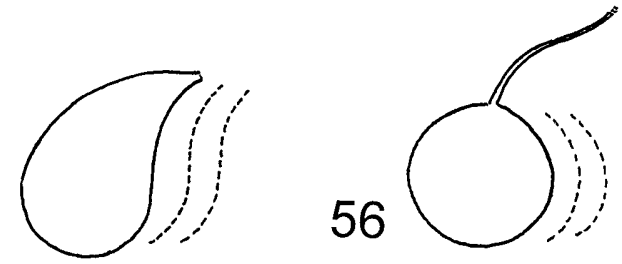

Figs 44-56. 44-45. Rhabdomastix (Rhabdomastix) beckeri (Lackschewitz, 1935) (Slovakia: Malé Trakany). 44 - male terminalia, general view, dorsal; 45 - female terminalia, general view, lateral. 46-56. Spermathecae. $46-R$. (R.) japonica Alexander, 1924; 47 - R. (R.) laeta (Loew, 1873); $48-R$. (R.) laetoidea sp. n.; $49-R$. (R.) borealis Alexander, 1924; 50 - R. (R.) edwardsi Tjeder, 1967; $51-R$. (R.) eugeni sp. n.; $52-R$. (R.) filata sp. n.; $53-R$. (R.) subparva Starý, 1971; $54-R$. (R.) hirticornis (Lackschewitz, 1940); $55-R$. (R.) georgica sp. n.; $56-R$. (R.) beckeri (Lackschewitz, 1935). Scale bars $0.25 \mathrm{~mm}$.

"Gonomyia schistacea Schumm." (hand-written in pencil), "Sac. beckeri nov. sp. det. Lacksch." (printed, orange). Accordingly labelled as lectotype ("Lectotype Rhabdomastix (s. str.) beckeri (Lacksch.) ô J. Starý 2003"). The specimen is micro-pinned on a stage of plant parenchyma, with only left hind leg present; left antenna and apex of abdomen broken off. Terminalia dissected and placed in Canada balsam between celluloid slides, pinned with the specimen. Paralectotype: 10 (ZMHB) with same labels as lectotype (incl. "61829"), except for the label with the schistacea identification. Terminalia dissected and placed in a sealed plastic tube with glycerine, pinned with the specimen. The paralectotype belongs to the species described here as $R$. $(R$.) eugeni sp. $\mathrm{n}$. and is also listed as paratype under that species. The specimen was examined by me in 1978 (later not traced again in ZMHB), and it was not labelled by me as the paralectotype of beckeri, nor the paratype of eugeni. Hence, the type series of $R$. (R.) beckeri is a mixed one, and the lectotype is designated here to maintain the current usage of the name for the species with the male terminalia as illustrated by Lackschewitz (1935, Figs 6a,b).

Other material examined $(57 \hat{\delta}, 20 \%)$ : Slovakia: Malé Trakany [7698], Tisa shores, 6.vi.1981, 60ิ, 5ㅇ, 9.vi.1981, 8ठ, 2ㅇ, 10.vi.1981, 1ㅇ, 12.vi.1981, 3ठิ, 7우, 25.vi.1983, 40ิ,

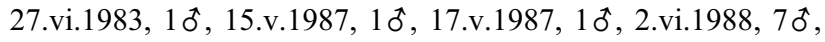
1, 1.vi.2000, 14 đิ, 30.v.2002, $12 \hat{\jmath}, 4$ (J. Starý leg.) (JSO).
Discussion. Some character traits of $R$. (R.) beckeri indicate a more distant relationship to the other species of the European Rhabdomastix s. str. In general appearance, $R$. (R.) beckeri is particularly distinctive by its somewhat milky wings with narrow darker seams along most of veins. The isolated position of $R$. (R.) beckeri is also indicated by some features in the structure of the generally rather robust male terminalia. Segment 9 is broad and short, broader than long, with a conspicuous triangular lobe dorsally at the posterior margin on each side of the median interruption (Fig. 44) (broader than long, but without any lobes, in the species centred around laeta; longer than broad, with only small lobes in the other species). In contrast to all the species, the outer gonostylus is unusually short and broad, the inner gonostylus conspicuously swollen and broadly rounded at apex and the interbases and the aedeagus is very slender. The female terminalia, although less distinctive, are well characterised by the shape of the cerci which generally are straight and broad, expanded and abruptly upturned before the apex.

Distribution. This species has so far been documented only from the type locality (Orsova, Romania) (Lackschewitz, 1935). 
It had been recorded from Slovakia by Starý (1987), but later this record was withdrawn (Starý, 1993, 1996). R. (R.) beckeri is very distinctive in the structure of the male terminalia, and the above specimens from Malé Trakany, Slovakia, had readily been identified with the figures by Lackschewitz (1935, Figs $6 \mathrm{a}, \mathrm{b})$. However, some doubts arose concerning the type [at that time, I had only examined the specimen listed here as paralectotype belonging to $R$. (R.) eugeni sp. n.]. The records from the former Czechoslovakia by Savchenko (1989) and Savchenko et al. (1992) are based on the same unpublished material from Slovakia sent by me to E.N. Savchenko. Here I am publishing the first documented records from Slovakia.

\section{DOUBTFUL SPECIES OF RHABDOMASTIX S. STR.}

\section{Limnobia schistacea Schummel, 1829}

Limnobia schistacea Schummel, 1829: 146 (description), Tab. 2, Fig. 2 (wing).

Gonomyia schistacea: Schiner, 1864: 544 (diagnosis in key, faun. record); Loew, 1873: 61 (note); Westhoff, 1882: 55 (faun. record); Beling, 1886: 195, 205 (description of larva, key) [? subparva, see Blanke \& Reusch, 1990: 706]; Osten Sacken, 1888: 201 (faun. record); Czwalina, 1893: 8 (faun. record in list); Strobl, 1895: 232 (faun. record); Strobl, 1901: 187 (faun. record); Kertész, 1903: 300 (Palaearctic catalogue); Lundström, 1907: 21 (diagnosis, faun. record), Fig. 25 (wing) [a species of laeta complex, possibly borealis]; Strobl, 1910: 276 (faun. record); Kuntze, 1914: 371 (key), Fig. 24 (wing); Riedel, 1918: 138 (faun. record); Riedel, 1919: 22 (faun. record); Pierre, 1924: 107, 109 (key), Fig. 408 (wing); Czižek, 1931: 79, 81 (diagnosis, faun. record, key), Figs 44a (male terminalia), b (wing) [subparva, see Starý, 1971: 154]; Reusch, 1988: 20, 26 (note); Blanke \& Reusch, 1990: 706 (note).

Goniomyia schistacea: Verrall, 1894: 76, 140 (faun. record, list) [unjustified emendation of genus name; not schistacea, see Edwards, 1938: 116].

Rhabdomastix (Sacandaga) schistacea: Edwards, 1921: 209 (note); Riedel, 1930: 73 (faun. record); Szilády, 1934: 146 (faun. record); Krzemiński, 1984a: 30 (faun. record); Mendl, 1986: 278 (note); Franz, 1989: 253 (faun. record); Savchenko et al., 1992: 316 (Palaearctic catalogue, note); Starý \& Oosterbroek, 1996: 72 (note).

Rhabdomastix schistacea: Lackschewitz, 1929: 208 (list); Edwards, 1938: 113, 115 (synonymy, key); Bangerter, 1939: 485 (faun. record) [subparva, see Mendl, 1979a: 355]; Bangerter, 1946: 192, 194 (faun. record) [subparva, see Mendl, 1979a: 355]; Tjeder, 1964: 146 (note); Mannheims, 1967: 473 (faun. record) [edwardsi, see present revision]; Nielsen, 1967: 323 (questioned name in list); Starý \& Rozkošný, 1970: 116 (faun. record, note; see subparva); Starý, 1971: 154 (note, see subparva); Mendl, 1979a: 355 (note).

Gonomyia (Rhabdomastix) schistacea: Lackschewitz, 1933: 252 (list); Lackschewitz, 1940: 56 (alternatively as Gonomyia (Sacandaga), faun. record) [edwardsi, crassa, filata, subparva; see present revision]

Note. A species probably based on an aberrant specimen, possibly discoloured. The name schistacea was in common usage for a long time mostly denoting various species of what is here established as the $R$. (R.) edwardsi complex $\left(R_{3}\right.$ more than its own length beyond tip of $R_{1}$, see Schummel, 1829, Tab. 2, Fig. 2). In theory, since the single type specimen is non-existent, a neotype of schistace $a$ could be designated, belonging to one of the species described herewith, say $R$. (R.) eugeni sp. n., to retain the name schistacea. However, a qualifying condition is not met requiring that "the neotype is consistent with what is known of the former name-bearing type from the original description ..." (Article 75.3.5. of ICZN, 1999) (see the discussion of schistacea above). An unrecognisable species.

ACKNOWLEDGEMENTS. For invaluable information and/or for the loan and gift of specimens, I am much indebted to the following: R. Contreras-Lichtenberg, P. Sehnal and A. Kaltenbach (NHMW), R. Crossley (York, England, UK), R. Danielsson and the late B. Tjeder (MZLU), G.B. Delmastro (Museo Civico di Storia Naturale, Carmagnola, Italy), V. Elsner (Zlín, Czech Republic), W. Geiger (Ligue suisse pour la protection de la nature, Neuchâtel, Switzerland), A. Godfrey (Barnsley, England, UK), J.-P. Haenni and Ch. Dufour (MHNN), W. Krzemiński (ISEZ), P. Lauterer (MMBC), the late J. Martinovský (Olomouc, Czech Republic), P. Oosterbroek (ZMAN), J. Roháček (SMOC), R. Rozkošný (Masaryk University, Brno, Czech Republic), J. Salmela (University of Jyväskylä, Finland), D. Simova-Tošić (Belgrade University, Belgrade, Serbia), B.J. Sinclair (ZFMK), A.E. Stubbs (Peterborough, England, UK), H. Wendt, W. Mey and H. Schumann (ZMHB), H.B. Williams and W.N. Mathis (USNM), and N.P. Wyatt and A.M. Hutson (BMNH). My special thanks are extended to H. Mendl (Kempten/Allgäu, Germany) and the late E.N. Savchenko (Kiev, Ukraine) with whom I discussed many problems concerning the genus Rhabdomastix and who supplied me with extensive material. The English text was checked and improved by F. Brodo (Ottawa, Canada). I also thank P. Oosterbroek and one anonymous reviewer for their comments. The work was supported by grant No. 206/01/1437 from the Grant Agency of the Czech Republic.

\section{REFERENCES}

Alexander C.P. 1924a: New species of two-winged flies from western North America belonging to the family Tipulidae. Proc. U.S. Nat. Mus. 64: 1-16.

AleXANDER C.P. 1924b: Undescribed species of Japanese crane flies. Part IV. Annu. Entomol. Soc. Am. 17: 59-74.

AleXander C.P. 1925a: Undescribed species of Japanese craneflies. Part V. Ann. Entomol. Soc. Am. 17: 431-448.

Alexander C.P. 1925b: Crane flies of the Maritime Province of Siberia. Proc. U.S. Nat. Mus. 68: 1-21.

AleXander C.P. 1940: New or little-known Tipulidae from Eastern Asia (Diptera), XLI. Philip. J. Sci. 71: 39-76.

AleXANDER C.P. 1954: Records and descriptions of Japanese Tipulidae (Diptera), Part III: The crane-flies of Shikoku. Philip. J. Sci. 82: 263-308.

AlEXANDER C.P. 1957: New or little-known Tipulidae (Diptera). CIV. Oriental-Australasian species. Ann. Mag. Nat. Hist. 10: 287-304.

AleXANDER C.P. 1964: New or little-known species of Asiatic Tipulidae (Diptera). I. Trans. Am. Entomol. Soc. 90: 205-234.

Alexander C.P. 1965: Family Tipulidae. In Stone A., Sabrosky C.W., Wirth W.W., Foote R.H. \& Coulson J.R. (eds): $A$ Catalog of the Diptera of America North of Mexico. U.S. Department of Agriculture, Washington, D.C., Agriculture Handbook 276, pp. 16-90.

Alexander C.P. \& Alexander M.M. 1973: Family Tipulidae. In Delfinado M.D. \& Hardy D.E. (eds): A Catalogue of the Diptera of the Oriental Region, 1. The University Press of Hawaii, Honolulu, pp. 10-224.

BANGERTER H. 1939: Die Eriopterini des Sensetales bei FlamattNeuenegg. Mitt. Schweiz. Entomol. Ges. 17: 482-487. 
Bangerter H. 1943: Die Eriopterini des Sensetales bei FlamattNeuenegg. II. Teil. Mitt. Schweiz. Entomol. Ges. 19: 20-22.

BANGerTER H. 1946: Weitere Limoniinae (Dipt.) aus dem Gebiet der Sense. Mitt. Schweiz. Entomol. Ges. 20: 189-196.

Bangerter H. 1947: Neue Eriopterini (Dipt. Tipulidae). Mitt. Schweiz. Entomol. Ges. 20: 353-380.

Beling T. 1886: Dritter Beitrag zur Naturgeschichte (Metamorphose) verschiedener Arten aus der Familie der Tipuliden. Verh. Zool. Bot. Ges. Wien 36: 171-214.

Blanke D. \& Reusch H. 1990: Stelzmücken in Emergenz- und Lichtfängen im Elfas, Südniedersachsen (Diptera Nematocera: Limoniidae). Braunschw. Naturkund. Schrift. 3: 699-710.

CASPERS N. 1980: Die Emergenz eines kleinen Waldbaches bei Bonn. Decheniana - Beihefte (Bonn) 23, 175 pp.

Caspers N. \& Noll R. 1981: Beitrag zur Kenntnis der Limoniidae, Trichoceridae und Tipulidae des Naturparkes Kottenforst-Ville (Insecta, Diptera, Nematocera). Decheniana (Bonn) 134: 197-214.

COE R.L. 1950: Tipulidae. In: Handbooks for the Identification of British Insects, 9(2). Royal Entomol. Soc., London, pp. $1-66$.

CzıžEK K. 1931: Die mährischen Arten der Dipterenfamilien Limoniidae und Cylindrotomidae. Z. Mähr. Landesmus. 28: $1-207$.

Czwalina G. 1893: Tipulidae. In: Neues Verzeichnis der Fliegen Ost- und Westpreussens. Beilage zum Osterprogramm des Altstädtischen Gymnasiums, Nr. 9. Hartungsche Buchdruckerei, Königsberg i. Pr., pp. 6-8.

DiENSKE J.W. 1987: An illustrated key to the genera and subgenera of the western Palaearctic Limoniidae (Insecta: Diptera), including a description of external morphology. Stuttgart. Beitr. Naturk. (A) 1987: 1-52.

EDWARDS F.W. 1921: British Limnobiidae: Some records and corrections. Trans. Entomol. Soc. London 1921: 196-230.

EDwards F.W. 1926: Additions to the list of British crane-flies. Entomol. Mon. Mag. 62: 31-35.

EDwards F.W. 1938: British short-palped craneflies. Taxonomy of adults. Trans. Soc. Br. Entomol. 5: 1-168.

Erhan-Dinca E. \& Ceianu I. 1986: Contributions to the knowledge of limoniid fauna (Diptera: Limoniidae) from the north of the eastern Carpathiens in Romania. Lucr. Celei de a III-a Conf. Entomol., Iasi 1986: 85-92 [in Romanian, English abstr.].

FALK S. 1991: A review of the Scarse and Threatened Flies of Great Britain (Part 1). Nature conservancy Council, Northminster House, Peterborough, 194 pp.

Franz H. 1989: Die Nordost-Alpen im Spiegel ihrer Landtierwelt, Band VI/1. Universitätsverlag Wagner, Innsbruck, 413 pp.

GoDfrey A. 2001: Species Recovery Programme. Survey for the cranefly Lipsothrix nigristigma in 2000. English Nature Reserve Reports No. 410, 47 pp.

Goetghebuer M. \& Tonnoir A. 1920: Catalogue raisonné des Tipulidae de Belgique. Bull. Soc. Entomol. Belg. 2: 104-112, $131-147$

Hackman W. 1980: A check list of the Finnish Diptera. I. Nematocera and Brachycera (s. str.). Notul. Entomol. 60: $17-48$.

Howe M. 1997: Abergavenny field meeting - June 1996. Bull. Dipterists Forum 44: 11-12.

Hutson A.M. \& Vane-Wright R.I. 1969: Corrections and additions to the list of British Nematocera (Diptera) since Kloet and Hincks" "A check list of British insects" (1945). Part 1. Entomol. Gazette 20: 231-256.
ICZN 1999: International Code of Zoological Nomenclature. 4th ed. The International Trust for Zoological Nomenclature, c/o The Natural History Museum, London, xxix + 306 pp.

IsHIDA H. 1960: The catalogue of the Japanese Tipulidae, with the keys to the genera and subgenera, VI. Limoniinae, tribe Eriopterini (1). Sci. Rep. Hyogo Univ. Agric., Ser. Nat. Sci. 4: 27-34.

Ishida H. 1965: The Check-list of the Japanese Tipulidae. 43 pp. [privately published]

Kertész K. 1903: Orthorrhapha nematocera. In Becker T., Bezzi M., Bischof J., Kertész K. \& Stein P. (eds): Katalog der Paläarktischen Dipteren, Band I. Budapest, 339 pp.

KrZEMiŃski W. 1984a: Limoniidae of Bulgaria (Diptera, Nematocera). I. Acta Zool. Bulg. 24: 27-34.

KRZEMIŃSKI W. 1984b: Limoniidae of Poland (Diptera, Nematocera). Part I: Subfamily Eriopterinae. Acta Zool. Cracoviensia 27: 437-518.

KRZEMIŃSKI W. 1991: 28. Diptera: Limoniidae. In Razowski J. (ed.): Checklist of Animals of Poland, II. Polska Akademia Nauk \& Instytut Systematyki i Ewolucji Zwierząt, Wrocław, Warszawa, Kraków, pp. 78-83.

KRZEMIŃSKI W. \& STARÝ J. 1989: Limoniidae of Bulgaria, II (Diptera, Nematocera). Pol. Pis. Entomol. 59: 253-279.

Kuntze A. 1914: Bestimmungstabellen der paläarktischen Eriopterinen (Diptera Nematocera Polyneura). Annln K. K. Naturh. Hofmus., Wien 28: 361-388.

LACKSCHEWITZ P. 1927: Revision der Gimmerthalschen und Sintenisschen Tipuliden. Korrbl. Naturf.-Ver. Riga 59: 1-8.

LACKSCHEWITZ P. 1929: Revision der v. Roser'schen Limnobiiden in der Württembergischen Naturaliensammlung in Stuttgart. Jahreshefte Ver. Vaterl. Naturk. Württemberg 85: 204-209.

LACKSCHEWITZ P. 1933: Revision der in Siebke's Catalogus Dipterorum angeführten Tipuliden. Norsk Entomol. Tidsskr. 3: $238-255$.

LACKSCHEWITZ P. 1935: Neue Eriopterinen (Dipt. Nematoc.) aus dem Deutschen Entomologischen Institut. Natuurh. Maandbl. 24: 9-14.

LaCKSCHEWITZ P. 1936: Über Ilisia obscuripes Zett. und zwei neue Eriopterinen (Dipt. Nemat.) aus Lappland. Norsk Entomol. Tidskr. 4: 110-116.

LACKSCHEWITZ P. 1940: Die paläarktischen Rhamphidiinen und Eriopterinen (Diptera) des Wiener Naturhistorischen Museums. Annln Naturh. Mus. Wien 50[1939]: 1-67.

Lantsov V.I. \& Chernov Yu.I. 1987: Tipuloidea in the Tundra Zone. Akad. Nauk SSSR, Nauka, Moskva, 176 pp. [in Russian].

Loew H. 1873: Beschreibungen Europäischer Dipteren. Dritter Band. H.W. Schmidt, Halle, 320 pp.

LundströM C. 1907: Beiträge zur Kenntnis der Dipteren Finnlands III. Cylindrotomidae und Limnobiidae. Acta Soc. Fauna Flora Fenn. 29: 1-32.

Mannheims B. 1964: Zur Kenntnis der Limoniiden Italiens. Boll. Ass. Rom. Entomol. 19: 3-7.

Mannheims B. 1967: Ergebisse der Albanien-Expedition 1961 des Deutschen Entomologischen Institutes. 63. Beitrag. Diptera: Limoniidae. Beitr. Entomol., Berlin 17: 459-476.

ManNheims B. \& SAVChenko E.N. 1973: Ergenisse der zoologischen Forschungen von Dr. Z. Kaszab in der Mongolei, Nr. 304. Limoniidae (Diptera). Ann. Hist. Nat. Mus. Nation. Hung. 65: 257-269.

MEIJERE J.C.H. DE 1920: Studien über palaearktische, vorwiegend holländische, Limnobiiden, insbesondere über ihre Kopulationsorgane. Tijdschr. Entomol. 63: 46-86.

MeIJerE J.C.H. DE 1935: Fifth addition to the new list of Dutch Diptera. Tijdschr. Entomol. 78: 188-230 [in Dutch]. 
MendL H. 1973a: Limoniinen aus dem Breitenbach (Diptera, Tipulidae). Schlitzer Produktionsbiologische Studien (4). Arch. Hydrobiol. 71: 255-270.

MendL H. 1973b: Limoniinen aus der Zoologischen Staatssammlung in München (Tipulidae, Diptera). Opusc. Zool., München 1973: 1-7.

MendL H. 1974: Limoniinen aus Norditalien (Diptera, Tipulidae). 6. Beitrag zur Kenntnis der Limoniinen-Fauna Italiens. Entomologica, Bari 10: 195-212.

MendL H. 1975: Limoniinen aus dem oberen Fulda-Gebiet insbesondere um Schlitz (Diptera, Tipulidae). Beitr. Naturk. Osthessen 1975: 183-206.

MendL H. 1977: Limoniiden (Diptera Nematocera) aus dem Allgäu. I. Voralpengebiet. Mitt. Münch. Entomol. Ges. 66: 101-125.

MendL H. 1978: Limoniidae. In Illies J. (ed.): Limnofauna Europaea. Gustav Fischer Verlag, Stuttgart, New York - Swets \& Zeitlinger B.V., Amsterdam, pp. 367-377.

MendL H. 1979a: Revision der Limoniiden-Sammlung von Hans Bangerter im Naturhistorischen Museum zu Bern/Schweiz. (Diptera: Nematocera). Beitr. Entomol., Berlin 29: 343-372.

MendL H. 1979b: Limoniidae (Diptera, Nematocera) aus dem Gebiet des Torneträsk (Schwedisch-Lappland). Fauna Norrlandica 5, $39 \mathrm{pp}$.

MendL H. 1984a: Limoniidenf'änge aus Jugoslawien (Diptera Nematocera, Limoniidae). Nachrbl. Bayer. Entomol. 33: $1-15$.

MendL H. 1984b: Beitrag zur Limoniiden-Fauna des VarangerGebietes (Norwegen: Sør Varanger/Fø und VarangerHalbinsel/Fn) (Diptera Nematocera, Limoniidae). Fauna Norrlandica 6, $20 \mathrm{pp}$.

MendL H. 1986: Stelzmücken aus Bulgarien. Spixiana 9: $275-282$.

Mendl H. \& Reusch H. 1989: Liste der aus der Bundesrepublik Deutschland bis jetzt bekannten Stelzmücken (Diptera Nematocera: Limoniidae). Braunschw. Naturkund. Schrift. 3: 429-453.

Nielsen P. 1925: Stankelben (The craneflies). Danmarks Fauna, København, 165 pp. [in Danish].

Nielsen P. 1967 Limoniidae. In Illies J. (ed.): Limnofauna Europaea. Gustav Fischer Verlag, Stuttgart, pp. 321-324.

Noll R. 1985: Taxonomie und Ökologie der Tipuliden, Cylindrotomiden, Limoniiden und Trichoceriden unter besonderer Berücksichtigung der Fauna Ostwestfalens (Insecta: Diptera). Decheniana - Beihefte (Bonn) 28, 265 pp.

Oosterbroek P. \& StarÝ J. 1995: Diptera Tipulomorpha. In Minelli A., Ruffo S. \& La Posta S. (eds): Checklist delle Specie della Fauna Italiana, 63. Edizioni Calderini, Bologna, pp. 1-16.

Osten SACKen C.R. 1888: Studies on Tipulidae. Part. II. Review of the published genera of the Tipulidae brevipalpi. Berlin Entomol. Z. 31[1887]: 163-242.

Pakalniškis S., Rimšaite J., Sprangauskaite-Bernotiene R., Butautaite R. \& Podenas S. 2000: Checklist of Lithuanian Diptera. Acta Zool. Lituan. 10: 3-58

Petersen F.T. \& Jong H. DE 2001: Limoniidae. In Petersen F.T. \& Meier R. (eds): A preliminary list of the Diptera of Danmark. Steenstrupia 26: 119-276.

Pierre C. 1924: Tipulidae. In: Faune de France, 8 (Diptères). Paris, $159 \mathrm{pp}$.

Podenas S. 1992: Tipulidae, Limoniidae, Cylindrotomidae, Trichoceridae and Ptychopteridae of Lithuania. Acta Zool. Cracoviensia 35: 147-156.

Podeniene V. 2001: Notes on the larva of Rhabdomastix (Sacandaga) laeta (Loew, 1873) (Diptera, Limoniidae). Acta Zool. Lituan. 11: 385-387.
Reusch H. 1988: Faunistische und phänologische Untersuchungen über Stelzmücken des Niedersächsischen Tieflandes (Diptera: Limoniidae). Braunschw. Naturkund. Schrift. 3: 171-203.

Reusch H. 1989: Stelzmücken im Tiefland Norddeutschlands (Diptera Nematocera: Limoniidae). Braunschw. Naturkund. Schrift. 3: 455-472.

Reusch H. 1999: Limoniidae. In Schumann H., Bährmann R. \& Stark A. (eds): Entomofauna Germanica 2. Checkliste der Dipteren Deutschlands. Studia Dipterologica, Halle (Saale), Supplement 2, pp. 55-60.

Reusch H. \& Oosterbroek P. 1997: Diptera Limoniidae and Pediciidae, short-palped crane flies. In Nilsson A.N. (ed.): Aquatic Insects of North Europe - A Taxonomic Handbook. Vol. 2. Apollo Books, Stenstrup, pp. 105-132.

Reusch H. \& Oosterbroek P. 2000: Übersicht der aus einzelnen deutschen Bundesländern bekannten Stelzmücken (Diptera: Limoniidae et Pediciidae). Braunschw. Naturkund. Schrift. 6: 149-164.

Reusch H. \& Zimmermann W. 2000: Beitrag zur StelzmückenEmergenz der Vesser im Thüringer Wald 1983, 1984 und 1987 (Diptera: Limoniidae et Pediciidae). Abh. Ber. Mus. Nat. Gotha 21: 41-48.

RiEDEL M.P. 1918: Elephantomyia westwoodi Osten-Sacken (Tipulidae, Dipt.) aus Ungarn. Ann. Mus. Nation. Hung. 16: 137-139.

RiedEL M.P. 1919: Die bei Frankfurt (Oder) vorkommenden Arten der Dipteren- (Nematocera polyneura-) Gattungen der Limnobiidae, Tipulidae und Cylindrotomidae. Entomol. Rundschau 36: 1-2, 8, 12-13, 17-18, 21-22, 24-25, 30, 36, 40-41.

Riedel M.P. 1930: Die subalpine Fliegenfauna von Reinerz (Glatzer Gebirge, Schlesien). Z. Wissenschaft. Insektenbiol. 25: 71-81.

Rotheray G.E. \& RoBertson D. 1993: Insects from shingle banks and riverside habitats in Strathspey. Malloch Soc. Res. Reports 2, 26 pp.

SAvCHENKo E.N. 1972: The limoniid-flies (Diptera, Limoniidae) collected by the Soviet-Mongolian zoological expeditions 1967-1969). In: Nasekomye Mongolii, 1. Nauka, Leningrad, pp. 721-738 [in Russian].

SAVCHENKo E.N. 1976: On finding Limoniid-flies (Diptera, Limoniidae) from the Palaeogonomyia Meunier subgenus of the Rhabdomastix Skuse genus in the USSR fauna. Dopovidi Akad. Nauk Ukrainskoi SSR 6: 561-564 [in Ukrainian, English abstr.].

SAvChENKo E.N. 1978a: Fauna of Limoniidae (Diptera) of the North Kuriles. Trudy Biologo-Pochvennogo Instituta, n. s. 49: 63-68 [in Russian].

SAVChENKo E.N. 1978b: Additions to the fauna of the limoniidflies (Diptera, Limoniidae) of the North Tien Shan. Vestnik zoologii 1978: 40-49 [in Russian, English abstr.].

SAvchenko E.N. 1980: New and little-known Limoniidae (Diptera) from the Zailiyskiy Alatau. Entomol. Obozr. 59: 391-403 [in Russian].

SAvChenKo E.N. 1982: Limoniidae: Eriopterinae. Fauna Ukraini 14 (3). Akad. Nauk Ukrainskoi SSR, Naukova Dumka. Kiev, 335 pp. [in Ukrainian].

Savchenko E.N. 1983: Limoniidae of the South Primorye. Akad. Nauk Ukrainskoi SSR, Naukova Dumka, Kiev, 156 pp. [in Russian].

SavChEnKo E.N. 1989: Limoniid-Flies of the Fauna of the USSR. Akad. Nauk Ukrainskoi SSR, Naukova Dumka, Kiev, 377 pp. [in Russian]. 
SavchenKo E.N. \& KrivolutsKaya G.O. 1976: Limoniidae of the South Kuriles and South Sakhalin. Akad. Nauk Ukrainskoi SSR, Naukova Dumka, Kiev, 160 pp. [in Russian].

Savchenko E.N., Oosterbroek P. \& Starý J. 1992: Family Limoniidae. In Soós Á., Papp L. \& Oosterbroek P. (eds): Catalogue of Palaearctic Diptera 1. Hungarian Natural History Museum, Budapest, pp. 183-369.

SAVChENKo E.N. \& PARKhomenKo S.I. 1980: Additional data on the fauna of Limoniidae (Diptera) of Chukotka. Freshwater Fauna of the Far East. Vladivostok, pp. 95-109 [in Russian].

SAVChenKo E.N. \& RYBIN S.N. 1982: Fauna of Limoniidae (Diptera) of the Alai Ridge. Entomol. Obozr. 61: 392-403 [in Russian].

SCHINER J.R. 1864: Fauna Austriaca. Die Fliegen (Diptera). II. Theil. Carl Gerold's Sohn, Wien, xxxii +658 pp.

Schummel T.E. 1829: Beschreibung der, in Schlesien einheimischen, Arten einiger Dipteren-Gattungen. I. Limnobia. Meigen. Beiträge zur Entomologie, I. Heft. Breslau, pp. 97-201.

Sidorenko V.S. 2001: Limoniidae. In Sidorenko V.S., Kupianskaya A.N., Leley A.S., Nemkov P.G. \& Kholin S.K. (eds): Key to the Insects of Russian Far East. Vol. VI. Diptera and Siphonaptera. Part 2. Dalnauka, Vladivostok, pp. 19-79 [in Russian, English abstr.].

Simova D. 1959: Beitrag zur Kenntnis der Tipuliden und Limnobiiden von Mazedonien (Diptera-Nematocera). Fragm. Balcan. 2: 125-135.

Stackelberg A.A. 1951: Materials on the dipteran fauna of the Leningradskaya oblast. 1. Nematocera polyneura (Diptera). Tr. Zool. Inst. Akad. Nauk SSSR 9: 703-742 [in Russian].

STARÝ J. 1970: Stand der faunistischen Forschung der Unterfamilie Limoniinae in der Tschechoslowakei (Tipulidae, Diptera). Infber. Landwirtschaft. Hochschule Nitra - Biolog. Grundlagen Landwirtschaft 1970: 29-53.

StARÝ J. 1971: Revision der Arten der Unterfamilie Limoniinae (Tipulidae, Diptera) aus den Sammlungen des Mährischen Museums in Brno mit besonderer Berücksichtigung der Fauna Mährens. Teil II: Tribus Hexatomini und Eriopterini. Cas. Morav. Muz. (Sci. Nat.) 55[1970]: 133-194.

STARÝ J. 1980: Revision des Materials der Familie Limoniidae aus den Sammlungen des Nationalmuseums in Prag (Diptera). Acta Faun. Entomol. Mus. Nation. Pragae 16: 33-54.

Starý J. 1984: Family Limoniidae. In Čepelák J. (ed.): Diptera of Slovakia I (Nematocera, Brachycera-Orthorrhapha) (Diptera of Slovakia). Veda, Bratislava, pp. 25-47 [in Slovak, English abstr.].

STARÝ J. 1987: Limoniidae. In: Ježek J. (ed.): Enumeratio insectorum Bohemoslovakiae - Checklist of Czechoslovak insects II (Diptera). Acta Faun. Entomol. Mus. Nation. Pragae 18: $17-25$.

STARÝ J. 1993: Nachträge und Berichtigungen zur LimoniidenFauna der Tschechoslowakei (Diptera), IV. Čas. Slez. Muz. Opava (A) 42: 123-135.

StarÝ J. 1995: Limoniidae. In Roháček J., Starý J., Martinovský J. \& Vála M. (eds): Diptera of the Bukovské Hills. SAŽP Správa CHKO a BR Východné Karpaty, Humenné, pp. 21-35 [in Slovak, English abstr.].

STARÝ J. 1996: New records of Limoniidae and Pediciidae (Diptera) from the Czech and Slovak Republics. Cas. Slez. Muz. Opava (A) 45: 119-124

StarÝ J. 1997: Limoniidae. In Chvála M. (ed.): Check List of Diptera (Insecta) of the Czech and Slovak Republics. Karolinum - Charles University Press, Praha, pp. 11-15.
StARÝ J. 2001: Faunistic records: Limoniidae. In: Dipterologica bohemoslovaca Vol. 10. Acta Univ. Carol. (Biologica) 45: 185-187.

StARÝ J. 2003: Revision of European species of the genus Rhabdomastix (Diptera: Limoniidae). Part 1: Introduction and subgenus Lurdia subgen. n. Eur. J. Entomol. 100: 587-608.

StARÝ J. \& Geiger W. 1998: 5. Limoniidae. In Merz B., Bächli J., Haenni J.-P. \& Gonseth Y. (eds): Diptera-Checklist. Fauna Helvetica 1. Centre suisse de cartographie de la faune \& Schweizerische Entomologische Gesellschaft, Neuchâtel, pp. 70-80.

Starý J. \& Oosterbroek P. 1996: Review of the Limoniidae and Pediciidae of Italy (Diptera, Tipuloidea). Fragm. Entomol. 28: 51-95.

StARÝ J. \& RoZkoŠnÝ R. 1970: Die slowakischen Arten der Unterfamilie Limoniinae (Tipulidae, Diptera). Acta Rerum Natur. Mus. Nat. Slovaci 15[1969]: 75-136.

Strobl G. 1895: Die Dipteren von Steiermark. III. Theil. Diptera Nematocera. Mitt. Naturw. Ver. Steiermark 31: 121-246.

STrobl G. 1901: Tief's dipterologischer Nachlass aus Kärnten und Oesterr.-Schlesien, bestimmt von Pr. Gabriel Strobl, nebst eigenen Funden aus Kärnten. Jahresber. Naturh. Landesmus. Kärnten 26: 171-246.

Strobl G. 1910: Die Dipteren von Steiermark. V. Theil, 2. Nachtrag. Mitt. Naturw. Ver. Steiermark 46[1909]: 45-293.

StubBs A.E. 1998: Limoniidae. In Chandler P.J. (ed.): Checklists of Insects of the British Isles (new series), Part 1: Diptera. Handbooks for the Identification of British Insects, 12. Royal Entomol. Soc., London, pp. 4-9.

SzILÁDY Z. 1934: Beiträge zur Dipterenfauna Bulgariens. Mitt. Bulg. Entomol. Ges. 8: 145-151.

Theowald BR. 1971: Die Tipuliden der Benelux-Länder (Diptera, Tipulidae). Tijdschr. Entomol. 114: 217-238.

TJEDER B. 1936: Beiträge zur Kenntnis schwedischer Diptera Nematocera 2-3. Entomol. Tidskr. 57: 132-135.

TJEDER B. 1947: Additions to the list of Swedish Tipulidae. Entomol. Tidskr. 68: 29-31.

TJEDER B. 1948: Insekter från södra Bohuslän 1946. Entomol. Tidskr. 69: 215-224 (in Swedish).

TJeDER B. 1955a: Five new Swedish craneflies (Dipt. Tipulidae). Opusc. Entomol. 20: 225-227.

TJEDER B. 1955b: Diptera: fam. Tipulidae. In: Catalogus insectorum Sueciae, XIV. Opusc. Entomol. 20: 229-247.

TJEDER B. 1964: Neuroptera, Trichoptera and Diptera - Tipulidae from Iceland with a redescription of Rhabdomastix parva Siebke. Opusc. Entomol. 29: 143-151.

TJEDER B. 1967: The identity of Rhabdomastix parva Edw., 1938 (Diptera: Tipulidae). Opusc. Entomol. 32: 225-227.

VerRall G.H. 1894: A second hundred new British species of Diptera. Entomol. Mon. Mag. 30: 76-79, 140-146.

Westhoff F. 1882: Ueber den Bau des Hypopygiums der Gattung Tipula Meigen, 1. Theil. Dissertation, Universität Münster, $62 \mathrm{pp}$.

WiedeńsKa J. 1986: Crane-flies (Diptera, Limoniidae) of Swiętokrzyskie Mts. Part I. Limoniidae of the Lubrzanka River valley. Fragm. Faun., Warszawa 30: 99-120 [in Polish, English abstr.].

WIEDEŃSKA J. 1991: Crane-flies (Diptera, Limoniidae) of the Świętokrzyskie Mountains. Part. II. Limoniidae of the Łysogóry Chain. Fragm. Faun., Warszawa 35: 49-64.

ZelenÝ J. 1972: Entwurf einer Gliederung der Tschechoslowakei für Zwecke der faunistischen Forschung (mit 5 Abb.). Zpr. Českoslov. Spol. Entomol. ČSAV 8: 3-16 [in Czech, German abstr.].

Received January 30, 2004; revised March 23, 2004; accepted June 10, 2004 